CAROLINE ARCANJO BUENO

ÁCIDO SALICÍLICO COMO SINALIZADOR DURANTE A EMBRIOGÊNESE DE Araucaria angustifolia (BERT.) O. KUNTZE.

São Paulo

2014 
CAROLINE ARCANJO BUENO

\section{ÁCIDO SALICÍLICO COMO SINALIZADOR DURANTE A EMBRIOGÊNESE DE Araucaria angustifolia (BERT.) O. KUNTZE.}

Dissertação apresentada ao Instituto de Biociências da Universidade de São Paulo, para obtenção do Título de Mestre em Ciências Biológicas, na Área de Botânica.

Orientadora: Eny lochevet Segal Floh 
Bueno, Caroline Arcanjo.

Ácido salicílico como sinalizador durante a embriogênese de Araucaria angustifolia (BERT.) O. Kuntze / Caroline Arcanjo Bueno. -- São Paulo, 2014. 83p

Dissertação (Mestrado) - Instituo de Biociências da Universidade de São Paulo. Departamento de Botânica

1. Ácido salicílico 2. Embriogênese 3. Araucaria. angustifolia Universidade de São Paulo. Instituto de Biociências. Departamento de Botânica. 
Caroline Arcanjo Bueno

Ácido salicílico como sinalizador durante a embriogênese de Araucaria angustifolia (BERT.) O. Kuntze.

Dissertação apresentada ao Instituto de Biociências da Universidade de São Paulo em de 2014, para a obtenção de Título de Mestre em Ciências Biológicas, na Área de Botânica.

$\operatorname{Prof}(\mathrm{a}) . \operatorname{Dr}(\mathrm{a})$.

$\operatorname{Prof}(\mathrm{a}) \cdot \operatorname{Dr}(\mathrm{a})$

Profa. Dra. Eny lochevet Segal Floh

Orientadora 
A Daniel Juan Penido, com todo o amor.

Dedico. 
"A semente ensina a não caber em si." Arnaldo Antunes. 


\section{AGRADECIMENTOS}

Agradeço a todos que conviveram comigo durante o período de realização do mestrado, tornando possível a realização deste trabalho.

Aos meus pais, Reinaldo e Leopoldo, minhas mães Claudia e Lourdes, aos meus irmãos Raphael e Arthur e minhas irmãs Camila e Flávia, por todo o apoio, incentivo e cuidado. Ao meu querido marido Daniel Juan por ser uma pessoa maravilhosa.

À profa. Eny Floh por me receber e oferecer a oportunidade de realizar um mestrado, por toda a orientação, confiança e paciência desde meu ingresso no BIOCEL.

Aos integrantes do BIOCEL durante o projeto, Carmem Silva, Leonardo Jo, Ana Carolina Abreu, Igor Sicchi, Jéssica Fernandes, Natália Piscirillo, Sâmila Lopes.

Aos integrantes atuais, Leandro de Oliveira, Bruno Navarro, Bruno Lira e Daniela por toda a amizade e apoio.

À profa. Magdalena Rossi por todo o suporte.

Aos doutores André dos Santos e Paula Elbl por todo o auxílio.

Aos amigos técnicos, Amanda Macedo, Leandro Salles e Sílvia Blanco por sempre estarem presentes e por tantos outros motivos.

Aos amigos pesquisadores, Juliana Almeida, Augusto Tomba, Roberta Martins e minha preciosa Fernanda Pieruzzi por todo o apoio, carinho, incentivo e descontração.

À Universidade de São Paulo pela oportunidade, condições de trabalho disponibilizadas e aos diferentes canais de aprendizagem oferecidos.

À Fundação de Pesquisa de São Paulo (FAPESP), pela bolsa concedida.

À Petrobrás pela bolsa concedida inicialmente e ao auxílio financeiro concedido ao BIOCEL.

Ao Instituto de Biociências (IB) onde o projeto foi executado. 
1.1. Embriogênese zigótica e somática em coníferas............................................11

1.2. Ácido salicílico (AS) e sua influência no cultivo in vitro de plantas....................15

1.3. O óxido nítrico (NO), as espécies reativas de oxigênio (ERO) e o equilíbrio

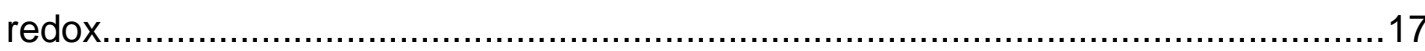

1.4. Expressão gênica de SERK durante a embriogênese somática........................20

1.5 Estudos de embriogênese em Araucaria angustifolia.......................................20

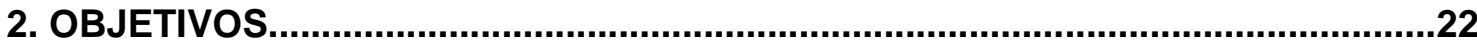

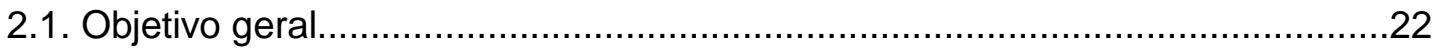

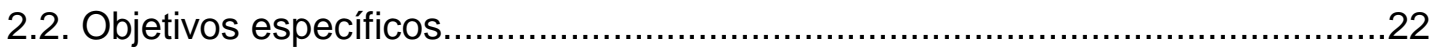

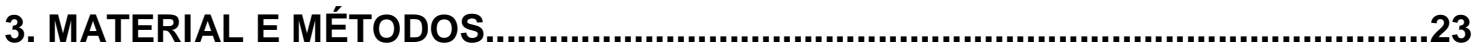

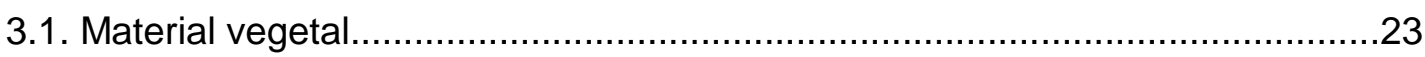

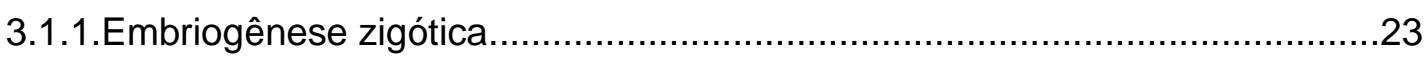

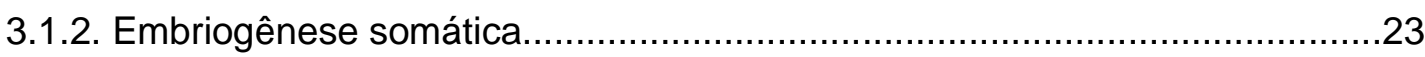

3.1.2.1. Indução das culturas embriogênicas.......................................................23

3.1.2.2. Proliferação e manutenção de linhagens embriogênicas estabelecidas...24

3.1.2.3. Estabelecimento de suspensões celulares.............................................25

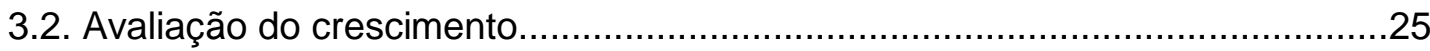

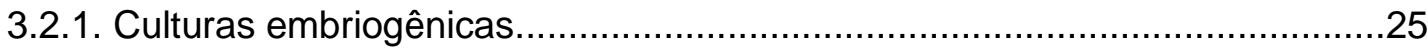

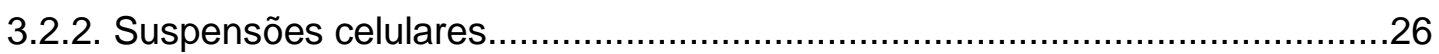

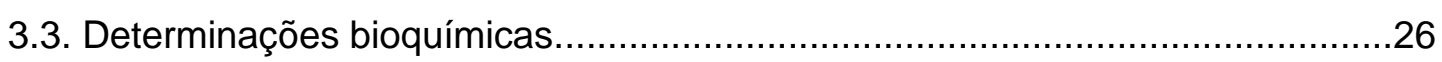

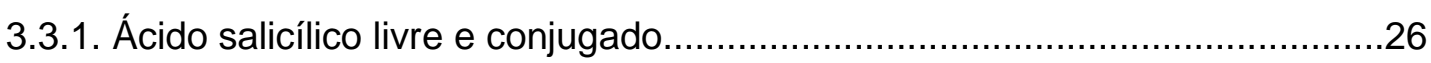

3.3.1.1. Extração do ácido salicílico (AS) livre e conjugado...................................26

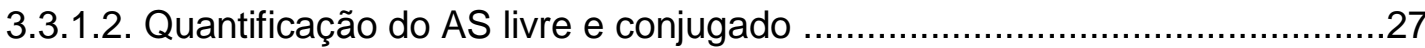

3.3.2. Quantificação e visualização do óxido nítrico (NO) e espécies reativas de

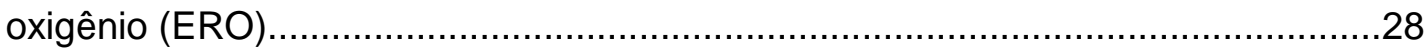

3.3.3. Efeito do doador, sequestrador e inibidor da síntese de NO sobre o conteúdo

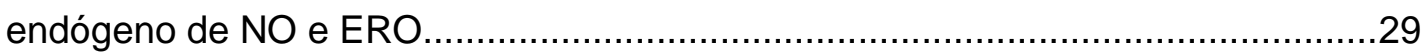

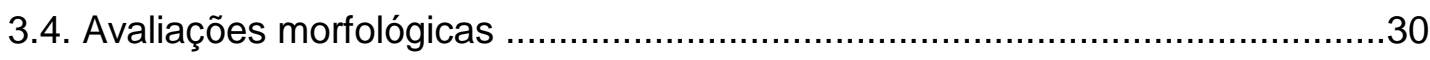

3.5. Expressão do gene AaSERK …..............................................................30

3.5.1. Extração de RNA e síntese de cDNA.....................................................30

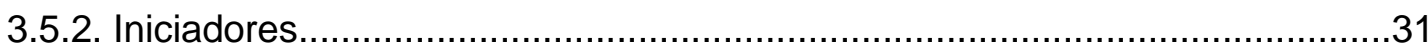

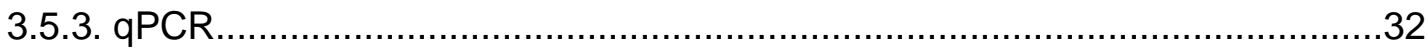

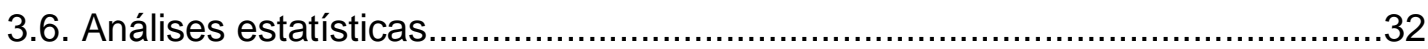

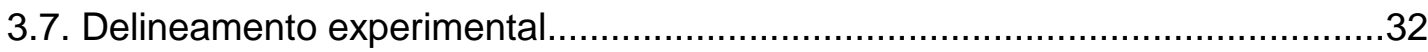

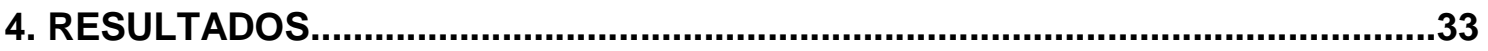

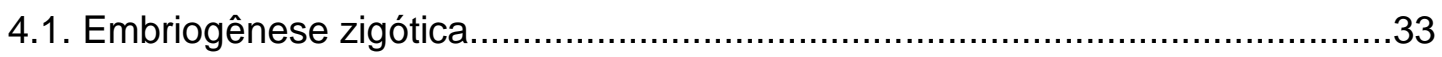


4.1.1. Conteúdo de AS e SAG em embriões zigóticos. .33

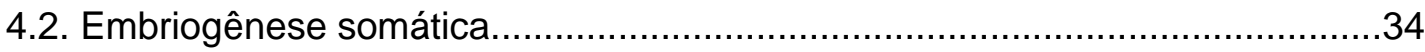

4.2.1. Indução de culturas embriogênicas em meio de cultura suplementado com diferentes concentrações de AS....................................................................34

4.2.2. Linhagens celulares com diferentes potenciais embriogênicos ..................35

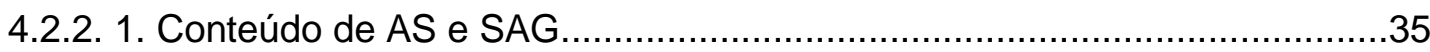

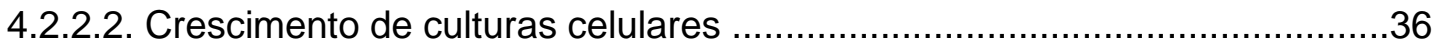

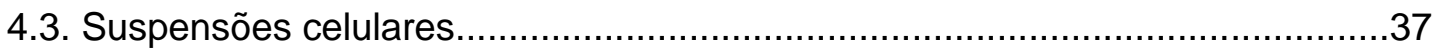

4.3.1. Dinâmica de crescimento de suspensões celulares....................................37

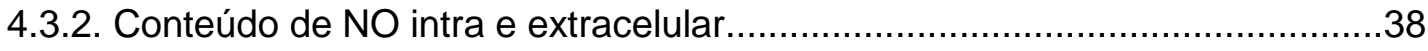

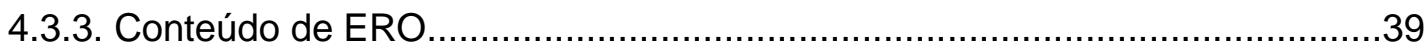

4.3.4. Efeito da suplementação de doador (GSNO) e inibidor (PTIO) ao meio de cultura na produção de NO intra e extracelular ...................................................40

4.3.5. Efeito da suplementação de doador (GSNO) e inibidor (PTIO) ao meio de cultura na produção de ERO..................................................................................43

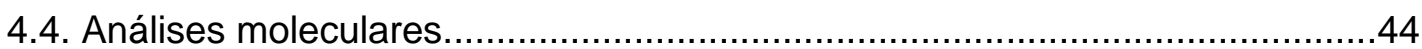

4.4.1. Avaliação da expressão do gene SERK em linhagens celulares com diferentes potencias embriogênicos proliferadas na presença do AS....................44

4.4.2. Expressão da SERK por qPCR em linhagens celulares proliferadas na

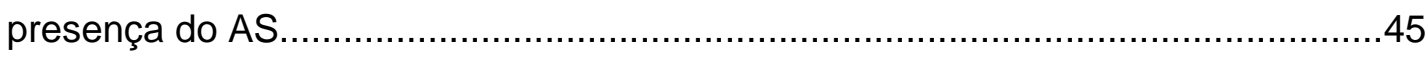

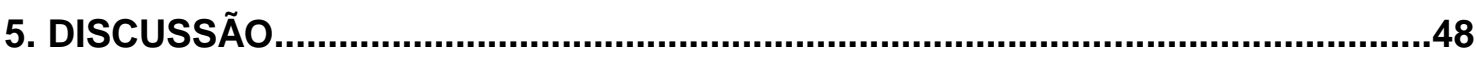

5.1. Conteúdo de AS e SAG em embriões zigóticos...............................................48

5.2. Efeito do AS na indução da embriogênese somática........................................49

5.3. Efeito do AS em meio líquido e semi-sólido na fase de proliferação das culturas embriogênicas

5.4. Efeito do AS, GSNO e PTIO na produção de NO e ERO em suspensões

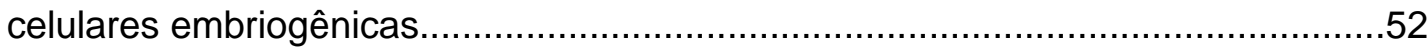

5.5. Expressão de SERK em culturas embriogênicas de Araucaria angustifolia.....54

6. CONCLUSÕES E PERSPECTIVAS FUTURAS.................................................57

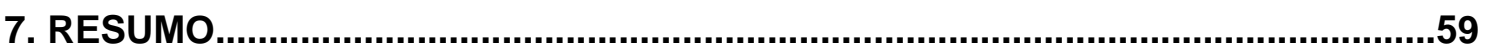

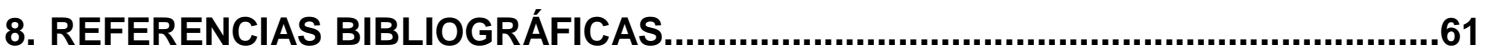


9. ANEXO.. 


\section{INTRODUÇÃO}

\subsection{Embriogênese zigótica e somática em coníferas}

A embriogênese vegetal inicia com o processo de fertilização e segue por uma sequência estereotipada de estádios característicos. O zigoto emprega todo o seu potencial genético em processos de divisões celulares complexas e consecutivas que resultam em um organismo pluricelular (Laux \& Jürgens, 1997). Adicionalmente consideráveis modificações na morfogênese ocorrem após a germinação da semente. No entanto, a fase embrionária é crucial uma vez que durante esta fase são especificados o meristema apical e radicular e demais padrões morfogenéticos (von Arnold et al., 2002). A embriogênese em gimnospermas diferencia-se em vários aspectos da embriogênese de angiospermas (Jurzitza, 1987) especialmente considerando-se 0 desenvolvimento do embrião. Em gimnospermas, o desenvolvimento do embrião tem início com uma fase de núcleo livre, enquanto em angiospermas a primeira divisão celular é acompanhada pela formação da parede celular (Singh, 1978; Kong et al., 1999; Hakman \& Oliviusson 2002). Nas gimnospermas, são reconhecidas três fases distintas durante o desenvolvimento embrionário: a) fase pró-embrionária- que vai desde a fertilização até o rompimento da arquegônia pelo pró-embrião (estádios anteriores ao alongamento do suspensor primário); b) fase embrionária inicial- compreendendo os estádios após o alongamento do suspensor secundário, e antes do estabelecimento dos meristemas; c) fase embrionária tardia- na qual a protoderme e o procâmbio são diferenciados e os meristemas apical e radicular são estabelecidos (Singh 1978; Haines \& Prakash, 1980). Tanto para gimnospermas como em angiospermas o desenvolvimento do embrião é finalizado com a completa formação dos cotilédones, acúmulo de substâncias de reserva (proteínas, lipídios e carboidratos), diminuição da atividade metabólica, e aquisição da tolerância à dessecação mediada ou não pelo hormônio ácido abscísico (ABA) (Bewley \& Black, 1994).

Os reguladores de crescimento vegetal são sinalizadores fundamentais para processos morfogenéticos como a embriogênese. Dentre estes reguladores, o ácido indol-3-acético (AIA) é uma das principais substâncias envolvidas no controle do desenvolvimento do embrião, determinando a orientação do eixo embrionário nas fases iniciais da embriogênese (Rock \& Quatrano, 1995; Kong et al., 1997; SantaCatarina et al., 2006; Casson \& Lindsey, 2006). Além de possuir um papel chave na comunicação celular (Kleine-Vehn \& Friml, 2008; Farias-Soares et al., 2014), a auxina atua especialmente no alongamento e diferenciação celular (Tanaka et al., 2014). 
Estudos realizados durante a EZ de $A$. angustifolia (Astarita et al., 2003a), demonstraram conteúdos maiores de AIA nos estádios iniciais do processo, seguido por um decréscimo contínuo até o final do desenvolvimento embrionário, durante a diferenciação dos cotilédones e desenvolvimento da semente.

Outro hormônio de crescimento importante durante o desenvolvimento de sementes de $A$. angustifolia é o ácido abscísico (ABA). O ABA, pertence à classe de metabólitos dos isoprenóides, tem seus níveis endógenos modulados por um preciso balanço entre sua biossíntese e o seu catabolismo (Nambara \& Marion-Poll, 2005). Diversos estudos demonstram o envolvimento do ABA na síntese de proteínas de reserva e lipídeos para a promoção da tolerância à dessecação e dormência, inibição da transição entre as etapas de maturação da semente e germinação, e entre o crescimento vegetativo e reprodutivo (Leung \& Giraudat, 1998; Nambara \& MarionPoll, 2005). Para o sistema $A$. angustifolia foi demonstrado que o conteúdo de ABA é baixo durante as fases iniciais da embriogênese, aumentando durante o crescimento do embrião, e decrescendo nas fases finais de desenvolvimento embrionário (Silveira et al., 2008).

As poliaminas (PAs) são aminas alifáticas de baixo peso molecular (Baron \& Stasolla, 2008; Santa-Catarina et al., 2006) e possuem papel importante em processos de desenvolvimento da planta como: divisão celular, regulação da morfogênese, embriogênese, floração, crescimento de raiz e tuberização (Baron \& Stasolla, 2008; Cangahuala-Inocente et al., 2013). As principais PAs encontradas nas células vegetais são: a diamina putrescina (Put), a triamina espermidina (Spd) e a tetramina espermina (Spm). Este grupo de substâncias inclui compostos nitrogenados alifáticos, positivamente carregados, em pH fisiológico, ocorrendo na forma livre ou conjugada com ácidos fenólicos e moléculas de baixo peso molecular (Bouchereau et al., 1999). Estas características permitem a interação com macromoléculas carregadas negativamente como DNA, RNA, proteínas e fosfolipídeos, participando da regulação das propriedades físicas e químicas das membranas e modulação das atividades enzimáticas (Galsto \& Sawhney, 1990). Astarita et al. (2003b) demonstraram, em $A$. angustifolia, que as PAs desempenham um papel relevante durante 0 desenvolvimento embrionário. Verificaram que a Put possui importância fundamental no início da embriogênese, quando a taxa de divisão celular é alta, enquanto altos conteúdos de Spd e Spm são essenciais ao final do desenvolvimento do embrião, quando o crescimento é devido, principalmente, ao alongamento celular. 
O sistema $A$. angustifolia apresenta longo ciclo de vida, fenologia irregular e um intervalo entre a polinização e formação da semente matura de três a quatro anos, situações que dificultam o estabelecimento de programas para melhoramento genético nesta espécie, O uso de técnicas biotecnológicas, como o cultivo in vitro, associado às características da embriogênese de coníferas (clivagem monozigótica) demonstram grande potencial de produção, a um custo baixo, de propágulos (Viana et al., 1997; Guerra et al., 2000; Steiner et al., 2008; Pullman \& Bucalo, 2014). Além disso, o cultivo in vitro propicia um ambiente controlado e de fácil manipulação para a realização de estudos envolvendo a elucidação de questões fisiológicas, bioquímicas e genéticas em etapas do desenvolvimento vegetal difíceis de serem analisadas devido a restrições físicas impostas pela estrutura vegetal (Attree \& Fowke, 1993; Jain \& Ishii, 1998; Park et al., 1998; Floh et al., 2007; Palovaara \& Hakman, 2008; Steiner et al., 2008).

A embriogênese somática (ES) é um processo no qual, através da técnica de cultivo in vitro, células isoladas, ou um pequeno grupo de células somáticas, originam embriões por meio de um processo morfogenético que se aproxima da seqüência de eventos existentes na embriogênese zigótica (Guerra et al., 1999; Tautorus et al., 1989; Cairney et al., 2006; Floh et al., 2007; Durzan, 2008; Palovaara \& Hakman 2008). O emprego da ES pode ter diferentes objetivos, que vão desde a obtenção de um modelo de referência para estudos básicos em biologia celular, fisiologia e bioquímica, até a propagação clonal, visando à conservação e o melhoramento genético das espécies. O potencial de propagação clonal e conservação ex situ obtido por meio da ES possibilita a conservação de espécies comerciais ou ameaçadas devido à alta exploração (Klimaszewska et al., 2011; Ma et al., 2012). A regeneração de plântulas utilizando a ES ocorre através de uma série de etapas de desenvolvimento e pode ser dividido em quatro fases: 1) a indução em meios de cultura contendo auxinas (mais frequente) e citocininas (menos frequente); 2) multiplicação em meios de cultura contendo auxinas em baixa concentração; 3) maturação em presença de ABA e/ou agentes osmóticos e; 4) germinação em meios de cultura isentos de fitorreguladores (Tautorus et al., 1991; von Arnold et al., 2002). Desde os primeiros relatos de ES em Picea abies e Larix decidua em 1985 (Chalupa 1985; Nagmani \& Bonga, 1985), diversas espécies de coníferas, principalmente Pinus, têm apresentado resposta ao processo (Pullman \& Bucalo, 2014).

A etapa de indução e controle da ES é dependente da fonte de explante, do genótipo da planta matriz, e do tipo e concentração dos reguladores de crescimento adicionados ao meio de cultura (Guerra et al., 1999). Em gimnospermas, as culturas 
embriogênicas (CEs) são caracterizadas como uma massa branco-translúcida contendo embriões somáticos bipolares. A presença de embriões bipolares contendo um longo sistema de suspensor é um marcador morfológico de culturas embriogênicas potencialmente aptas para o processo de maturação e germinação de plântulas (von Arnold et al., 2002). O uso de meio de cultura condicionado também pode induzir e modular a ES através da ação de moléculas sinalizadoras, incluindo PAs, proteínas arabinogalactanas e lipoquitooligossacarideos, ABA e giberelinas (GA) (von Arnold et al., 2005; Silveira et al., 2006; Santa-Catarina et al., 2007; Nolan et al., 2014).

A etapa de multiplicação das culturas embriogênicas apresenta três estádios de desenvolvimento caracterizados por agregados celulares definidos como massas próembriogênicas (MPE) dos tipos MPE I, II e III. As MPE I são formadas por um aglomerado de pequenas células de citoplasma denso (Halperin, 1966), associadas a uma célula altamente vacuolada. Um conjunto semelhante, mas com mais de uma célula vacuolada, caracteriza a MPE II. Na fase de MPE III, o conjunto de células aumenta e fica rodeado por células vacuoladas (Filonova et al., 2000). O embrião propriamente dito é formado a partir das MPE III, através do processo de bipolarização (Filonova et al., 2000; Stassola \& Yeung, 2003). O conjunto de células pequenas e aglomeradas é denominado pró-embrião, e as células altamente vacuoladas são denominadas suspensores. Geralmente, a composição dos meios de cultura utilizados na etapa de proliferação é similar aos utilizados durante a etapa de indução (Attre e Fowke, 1993; von Arnold et al., 2002).

A maturação é uma etapa fundamental durante o desenvolvimento embrionário, na qual os embriões somáticos apresentam várias alterações bioquímicas, resultando no acúmulo de substâncias de reserva e aquisição de tolerância à dessecação (Thomas, 1993; von Arnold et al., 2002; Stasolla et al., 2003). Uma das principais estratégias para maturação de CEs é a suplementação do meio de cultura com determinados reguladores de crescimento e agentes osmóticos, permitindo a progressão do desenvolvimento normal dos embriões somáticos (Stasolla \& Yeung, 2003; Stasolla et al., 2003; dos Santos et al., 2008). Este estímulo equivale à desidratação ocorrida nas sementes, durante os estádios finais da maturação do embrião zigótico, resultando na finalização do desenvolvimento embrionário (Bewley \& Black, 1994; Stasolla et al., 2003). A combinação de ABA com agentes osmóticos mostrou-se eficiente para o processo de maturação em várias espécies vegetais, especialmente em coníferas (Tautorus et al., 1991; Attree \& Fowke, 1993; Stasolla \& Yeung, 2003; Steiner et al., 2008). O principal papel exercido pelo ABA durante a 
maturação é a inibição da proliferação das CEs e indução do desenvolvimento e maturação dos embriões somáticos (von Arnold et al., 2002). Durante esta etapa, os embriões apresentam mudanças morfológicas (degradação do suspensor) e bioquímicas (acúmulo de substâncias de reserva, redução da atividade metabólica e aquisição da tolerância à desidratação) (Stasolla \& Yeung, 2003; von Arnold et al., 2002; Farias-Soares et al., 2014).

$\mathrm{Na}$ etapa de conversão em plântulas, ocorre a germinação dos embriões que passaram pela dessecação, geralmente em meio de cultura isento de fitorreguladores, obtendo-se as plântulas. Quando o sistema radicular encontra-se bem desenvolvido, com a presença de raízes laterais, as plantas provenientes de embriões somáticos podem ser aclimatizadas ex vitro (Högberg et al., 2003).

Em estudos da ES de A. angustifolia, Steiner et al. (2005) observaram maior quantidade de Put, seguida pela Spd e Spm, favorecendo a manutenção da divisão celular. Quando essas culturas foram suplementadas com Spm e Spd, ocorreu um maior acúmulo de matéria seca e uma maior deposição de substâncias de reserva, como proteínas e amido. Ao adicionar a Spd ao meio de cultura, ocorre um aumento no conteúdo endógeno de ABA. Silveira et al. (2006) sugeriram que as PAs, Spd e Spm, reduzem o crescimento celular e o conteúdo endógeno de óxido nítrico (NO), além de promoverem a progressão da morfologia dos pró-embriões em CEs de $A$. angustifolia. Além disso, sugeriram uma possível correlação entre a produção de NO, induzida ou não pelas PAs, e a aquisição de competência para a embriogênese. $O$ efeito da aplicação exógena de um doador de NO foi avaliado por Osti et al. (2010) também neste sistema, onde verificaram que a adição de NO interfere no crescimento celular, dentro de um limite de concentração, quando suplementado ao meio de cultura. Jo et al. (2013) sugeriram que o potencial embriogênico das CEs de $A$. angustifolia poderia ser manipulado pela otimização dos níveis endógenos de PAs.

Além dos reguladores de crescimento citados, substâncias como o ácido jasmônico, brassinosteróides, ácido salicílico e oligossacarídeos também apresentam envolvimento no processo de ES (von Arnold et al., 2002; Jimenez, 2005).

\section{2. Ácido salicílico (AS) e sua influência no cultivo in vitro de plantas}

O ácido salicílico (AS) é um derivado fenólico e produto natural do metabolismo dos fenilpropanóides presente nos vegetais. Sua biossíntese envolve a descarboxilação do ácido transcinâmico para ácido benzóico, e duas subseqüentes hidroxilações (Hayat et al., 2007). Em plantas, o AS tem sido classicamente 
referenciado como uma mólecula endógena sinalizadora de processos envolvendo a defesa contra o ataque de patógenos (Ward et al., 1991; Metraux, 2002) ou então mediando as respostas a estresses ambientais como o salino, hídrico ou de temperatura (Shakirova, 1997, Bezrukova, 2001; Senaratna, 2000).

Quando aplicado exogenamente, o AS pode ser metabolizado ou conjugado (Popova et al., 1997). A maior parte do AS produzido na planta é convertido a AS O- $\beta$ glicosídeo (SAG) por uma glicosil transferase (Vlot et al., 2009). A ação do hormônio livre é principalmente inativada por oxidação ou conjugação com monossacarídeos. $A$ conjugação não só inativa o hormônio, mas promove uma forma de armazenamento já que a forma livre ocorre no citosol e a conjugação, nos vacúolos (Taiz \& Zeiger, 2009). O AS é transportado ativamente do citosol ao vacúolo, permanecendo estocado em formas conjugadas e inativas que podem ser facilmente reconvertidas em AS livre (Dean \& Mills, 2004; Dean et al., 2005). Outra forma conjugada do AS é o metil salicilato (MeSA), uma molécula gasosa que promove sinalização rápida, ou é estocada como MeSA 2-O-b-D-glucose, ao ser glucosilada (Sahu, 2013).

Gill \& Tuteja (2010) sugeriram que a diferenciação do embrião somático pode compartilhar a via de sinalização de salicilatos como o AS. Os processos fisiológicos influenciados por AS incluem germinação, crescimento vegetativo, respiração, termogênese, senescência, regulação estomática, fotossíntese e tolerância a estresse (Agami \& Mohamed, 2013; Tirani et al., 2013). Além disso, o AS pode contribuir na manutenção do equilíbrio oxidativo regulando a atividade de enzimas antioxidantes (Durner \& Klessig, 1996; Slaymaker et al., 2002; Rivas \& Plasencia, 2011) e na modulação de morfogênese in vitro (Orenes et al., 2013).

Pesquisas in vitro têm sido conduzidas relacionando a suplementação do meio de cultura com AS a processos de estresse e de proteção ao estresse (termotolerância, tolerância ao resfriamento e salinidade) em plantas (Lopez-Delgado et al., 2007). Estudos sugerem que a atuação do AS promove a indução e desenvolvimento de embriões somáticos (Yeh \& Chang, 1987; Hutchinson, 1996; Pius, 1993). Em Coffea arabica, a suplementação com concentrações picomolares de AS em culturas celulares embriogênicas, resultou no aumento do crescimento celular e na sincronização do desenvolvimento de embriões somáticos (Quiroz-Figueroa et al. 2001). De acordo com Neill et al. (2002) no sistema Arabidopsis thaliana, a ação do AS pode estar relacionada com a geração de óxido nítrico (NO) e espécies reativas de oxigênio (ERO), em especial de $\mathrm{H}_{2} \mathrm{O}_{2}$. Em suspensões celulares de Ginko biloba, o AS tem sido utilizado visando aumento da concentração de metabólitos secundários 
(bilobalides e ginkgolides) no meio de cultura (Kang et al., 2006). Estudos com coníferas descrevem que o AS pode promover o desenvolvimento de embriões somáticos em culturas embriogênicas de Pinus roxburghii (Mulgund et al., 2012). O efeito da suplementação com AS exógeno no crescimento e desenvolvimento vegetal é dependente da espécie, grau de diferenciação do tecido e concentração de AS aplicada (Shakirova et al., 2003; Abreu \& Munne'-Bosch, 2009).

\subsection{O óxido nítrico (NO), espécies reativas de oxigênio (ERO) e o equilíbrio redox}

As fases iniciais da embriogênese em plantas são marcadas por uma intensa atividade metabólica, alta taxa de divisão celular e produção de NO e ERO. As vias de sinalização do NO e das ERO são conectadas, e ambos os compostos podem modular a expressão de genes envolvidos na resposta primária ao estresse ou na sinalização hormonal, fundamental para a resposta morfogenética (Scheler et al., 2013). A manutenção do equilíbrio redox entre o sistema pró-antioxidante e anti-oxidante, tem sido considerada importante em processos de diferenciação celular, como a ES (Stasolla \& Yeung, 2001; Zhang et al., 2010). O estado redox é determinante na função celular (Dietz \& Scheibe, 2004) e pode sofrer um desbalanço entre as ERO, o NO, uma variedade de condições estressantes, tanto bióticas quanto abióticas, desencadeia um aumento de ERO em células animais e vegetais (Mahalingam \& Fedoroff, 2003). A interferência do estado redox é classificada como estresse oxidativo, um evento capaz de ocasionar diversas modificações que afetam o crescimento e desenvolvimento das plantas, e desencadeiam uma gama de respostas, a partir da alteração de expressão gênica e modificação no metabolismo celular (Kacperska, 2004).

Estudos relacionam a influência de estresse oxidativo durante a formação das fases embrionárias iniciais em plantas e animais, aumentando o interesse da incorporação do AS embriogênese (Lopes et al., 2010; Zhang et al., 2010). O AS interage em sistemas de sinalização junto ao $\mathrm{NO}$ e ERO, unificando suas funções regulatórias. Pan et al. (2009) observaram que em Citrus sinensis três proteínas relacionadas ao estresse oxidativo foram reguladas na maturação da $E S$, indicando que o estresse oxidativo pode levar à diferenciação das células e promover a formação de embriões somáticos. Em Arabidopsis foi demonstrado que o AS induziu duas superóxido dismutases, o que pode contribuir para o aumento da capacidade antioxidante do organismo pela diminuição do radical superóxido (Rajjou et al., 2006). Além disso, o AS pode inibir a ação das enzimas catalase e ascorbato peroxidase, 
contribuindo para a estabilização dos níveis de $\mathrm{H}_{2} \mathrm{O}_{2}$ (Chen et al., 1993; Durner \& Klessig, 1996). Outro aspecto importante na regulação do desenvolvimento envolve o AS e as Mitogen-activated protein kinases (MAPK), cuja sinalização é importante para mediar a interação entre o AS e as ERO. As MPK3 e MPK6 promovem a biossíntese de AS e a expressão dos genes PR, diretamente ligados à sinalização do AS (Bartels et al., 2009; Foreman et al., 2003).

O aumento dos níveis de ERO causado pelo estresse oxidativo,em decorrência da adição de diferentes promotores de maturação (ABA e agentes osmóticos) nas culturas in vitro,pode promover a ES em diversas espécies de plantas (Caliskan et al., 2004; Ganesan \& Jayabalan 2004; Luo et al., 2001; Pasternak et al., 2002; Andrade, 2010). Durante a indução da ES, as culturas celulares apresentam um processo rápido de proliferação celular e metabolismo aeróbico ativo, promovendo o acúmulo de ERO em células embriogênicas (Stasolla et al., 2004). Em suspensões celulares de $A$. angustifolia, a proliferação das células foi afetada quando da incorporação de diferentes concentrações de NO (Osti et al., 2010; Andrade 2010). Andrade (2010), propôs que, neste sistema vegetal os agentes promotores de maturação reduzem a síntese endógena de NO e ERO, e que o bloqueio dos estímulos necessários para a formação do embrião ocorre após a sinalização de NO.

O NO é um radical livre, gasoso, altamente reativo e difusível. Tem sido descrito como um mensageiro intra e intercelular, podendo participar de vários processos em plantas (Neill et al., 2003). Estudos apontam o NO como uma molécula sinalizadora nos mecanismos de defesa, nas respostas ao estresse biótico e abiótico, e na regulação do crescimento, diferenciação e desenvolvimento vegetal (SantaCatarina et al., 2007; Yu et al., 2014). O NO interage com muitas moléculas sinalizadoras envolvidas em respostas adaptativas das plantas, incluindo ABA e ERO (Romero-Puertas et al., 2004; Neill et al., 2003). Além disso, afeta diretamente a atividade de algumas enzimas envolvidas na biossíntese da lignina, induz o acúmulo AS (Delledonne, 2005) e aumenta a capacidade antioxidante das plantas, reduzindo danos causados por ERO (Bai et al., 2011).

Alguns autores consideram o NO como um agente indutor de estresse (Leshem \& Haramaty, 1996), outros têm relatado seu papel como protetor (Beligni \& Lamattina, 1999; Hsu \& Kao, 2004), dependendo da concentração, tecido vegetal e tipos de estresse. $\mathrm{O}$ fato do NO ser um radical livre altamente reativo permite sua ação como sequestrador de moléculas intermediárias em diferentes processos metabólicos (Kopyra \& Gwózdz, 2003). O NO pode atuar como um agente antioxidante, 
diretamente na remoção de $\mathrm{ERO}$, tais como $\mathrm{O}_{2^{-}}$(superóxido), para formar 0 peroxinitrito (ONOO-) (Laspina et al., 2005; Scheler et al., 2013). Orozco-Cárdenas e Ryan (2002) demonstraram que o $\mathrm{NO}$ bloqueia a produção de $\mathrm{H}_{2} \mathrm{O}_{2}$ induzida por ácido jasmônico em Lycopersicon esculentum Mill. Sun et al. (2007) relataram que em Zea mays L., o acúmulo de NO auxiliou na diminuição do dano causado pelo estresse oxidativo induzido por deficiência de ferro por sua reação direta com as ERO ou alterando a atividade de enzimas sequestradoras de ERO. Foi também demonstrado que o NO pode estimular a ativação da divisão celular e a formação de células embriogênicas de protoplastos de Medicago sativa (Ötvos et al., 2005). Estudos realizados por Silveira et al. (2006) também evidenciaram que as células embriogênicas de $A$. angustifolia acumulam mais NO do que as células do suspensor, sugerindo diferenças fisiológicas em relação à biossíntese de NO nestas estruturas.

As $\mathrm{ERO}$, como $\mathrm{O}_{2^{-}}$(superóxido), $\mathrm{H}_{2} \mathrm{O}_{2}$ (peróxido de hidrogênio) e $\mathrm{OH}$ - (radical hidroxila) (Hegedus et al., 2001), são moléculas altamente reativas (Mehdy et al., 1996), produzidas nos cloroplastos, mitocôndrias e peroxissomos, como produtos secundários da fotossíntese e respiração (Apel \& Hirt, 2004). No entanto, diversos fatores bióticos ou abióticos, tais como excesso de luz, injúrias ao tecido (Olson \& Varner, 1993), luz UV, extremos de temperatura, poluentes do ar e ataque de fitopatógenos (Allan \& Fluhr, 1997; Torres, 2010) podem aumentar sua produção (Resende et al., 2007). Esse aumento de produção de ERO gerado por algum fator estressor, ou um conjunto deles, é conhecido como explosão oxidativa, que participa de um sistema integrado e amplificado de sinalização, envolvendo o AS no disparo dos mecanismos de defesa (Lamb \& Dixon, 1997). A rápida geração e acúmulo de ERO atuam em diferentes funções de defesa. O acúmulo de ERO pode apresentar efeito tóxico para a célula, levando a danos oxidativos, e finalmente induzir à morte celular (Imai \& Nikagawa, 2003; Nordberg \& Arner, 2001). Radicais como superóxido e o peróxido de hidrogênio podem regular a atividade de várias quinases e fatores de transcrição. Em decorrência da elevada produção de ERO, sistemas detoxificantes como a NADH dehydrogenase, oxidase alternativa (AOX) e proteínas mitocondriais (PUMP) são ativados (Pastore et al., 2007; Valente et al., 2012). O peróxido de hidrogênio atua também como responsável da ativação da hidrolase do ácido benzóico, enzima responsável pela conversão do ácido benzóico em AS (Resende et al., 2003). 


\subsection{Expressão gênica de SERK durante a embriogênese somática}

O desenvolvimento embrionário vegetal é um processo complexo operado por centenas de genes e influenciado por múltiplos fatores ambientais (Vestman et al., 2011). Os processos moleculares que governam a competência para a embriogênese em células vegetais ainda não estão totalmente esclarecidos (Mordhost et al. 1997). As dificuldades se devem em parte pela falta de conhecimento dos mecanismos genéticos que regulam a embriogênese.

Diversos estudos têm como principal objetivo a identificação de culturas celulares competentes para embriogênese (Bonga et al., 2010; Mordhorst et al., 2005). Um dos primeiros genes descritos como envolvidos na expressão da competência celular foi o "Somatic Embryogenesis Receptor Kinase" (DcSERK) (Schmidt et al., 1997), em cultura de tecidos de Daucus carota. A expressão diferencial do gene $S E R K$, em resposta ao estresse abiótico in vitro tem sido utilizada como um sinalizador para o reconhecimento de células embriogênicas competentes e não competentes em Ocotea catharinensis (Santa-Catarina et al., 2004), Arabidopsis thaliana (AtSERK1) (Hecht et al., 2001), Vitis vinifera (VvSERK1, VvSERK2, VvSERK3) (Schellenbaum et al., 2008), Medicago trunculata (MtSERK1) (Nolan et al., 2003) e Araucaria angustifolia (AaSERK1) (Steiner, 2012). Apesar de estar normalmente associado à indução da ES e apomixia, o gene SERK também tem sido associado à modulação de respostas fisiológicas e de diferenciação celular em plantas submetidas a estresses bióticos e abióticos (Santos \& Aragão, 2009).

Os genes da família SERK agem em várias vias de sinalização. Devido à sua interação com os receptor-like kinases, os SERK participam de múltiplos processos de desenvolvimento (Du et al., 2012; Gou et al.,2012). Os SERK1 e 2 estão envolvidos na esporogênese, enquanto o SERK3 atua na via de sinalização de brassinosteróides (Roux et al., 2011). Devido a estas interações, a elucidação do papel dos SERK em sinalizações específicas e nas alterações de respostas fisiológicas, promoveria maior compreensão sobre a função destes genes (van Esse et al., 2013).

\subsection{Estudos de embriogênese em Araucaria angustifolia}

Estudos dos aspectos bioquímicos, fisiológicos e moleculares durante 0 desenvolvimento do embrião zigótico, visando uma abordagem integrativa com o processo de ES em $A$. angustifolia têm sido desenvolvidos por vários pesquisadores. Dentre eles, destacam-se os trabalhos relativos ao envolvimento do AIA (Astarita et al., 2003a), ABA (Silveira et al., 2008), poliaminas (Astarita et al., 2003b; Jo et al., 
2013), aminoácidos (Astarita et al., 2003c), óxido nítrico (Silveira et al., 2006), proteínas (dos Santos et al., 2006; Silveira et al., 2008; Balbuena et al., 2009) e o perfil transcricional (Elbl et al., 2014), durante a embriogênese (Floh et al., 2007; Steiner et al., 2008). Estes estudos, além de propiciarem o conhecimento dos aspectos básicos do processo de embriogênese, têm sido utilizados para um aprimoramento dos protocolos para desenvolvimento dos embriões somáticos.

A estratégia para o desenvolvimento de um protocolo eficiente de ES para $A$. angustifolia tem sido baseada em estudos comparativos entre a embriogênese zigótica e somática, nos aspectos bioquímicos, moleculares e fisiológicos (Astarita et al., 2003a, Astarita et al., 2003b, Astarita et al., 2003c, dos Santos et al., 2006; Silveira et al., 2008; Steiner et al., 2008; Balbuena et al., 2009). Apesar dos avanços obtidos com a indução e estabelecimento de linhagens celulares embriogênicas de $A$. angustifolia (Astarita \& Guerra, 1998; Santos et al., 2002; Silveira et al., 2002; Steiner et al., 2005; dos Santos et al., 2008, Steiner et al., 2008, Jo et al., 2013), a maturação e a regeneração de plântulas a partir de embriões somáticos, ainda é incipiente. As limitações associadas ao desenvolvimento da ES em coníferas podem estar relacionadas com o uso de condições sub-ótimas de meio de cultura utilizadas, em especial durante a fase inicial do processo. De acordo com Stasolla et al. (2002), a otimização das fases iniciais no desenvolvimento embrionário é essencial para que não sejam acumulados erros nas etapas seguintes.

Apesar dos relatos sobre os efeitos da suplementação de AS ao meio de cultura como promotor do aumento de ocorrência da ES, raros estudos contemplaram a ação deste regulador na ES de coníferas (Mulgund et al., 2012). Até o presente momento, não foram conduzidos estudos no sentido de verificar o efeito do AS no metabolismo endógeno de NO e ERO e no crescimento de culturas embriogênicas de A. angustifolia. Estudos neste sentido são fundamentais para o entendimento dos eventos bioquímicos associados à ES dessa espécie. 


\section{OBJETIVOS}

\subsection{Objetivo geral}

Estudar a participação do ácido salicílico (AS) como sinalizador do processo de embriogênese zigótica e somática em $A$. angustifolia.

\subsection{Objetivos específicos}

- Avaliar os níveis de AS em sementes durante diferentes fases de desenvolvimento da embriogênese zigótica;

- Avaliar o efeito da adição exógena de AS na fase de indução e proliferação das linhagens celulares embriogênicas com diferentes potenciais de maturação;

- Avaliar o efeito da adição exógena de AS na produção intra e extracelular de NO e ERO em culturas embriogênicas com diferentes potenciais de maturação;

- Avaliar o efeito da adição exógena de GSNO e PTIO na produção intra e extracelular de NO e ERO em culturas embriogênicas com diferentes potenciais de maturação.

- Avaliar a expressão do gene SERK na fase de proliferação da linhagem responsiva aos agentes de maturação. 


\section{MATERIAL E MÉTODOS}

\subsection{Material vegetal}

\subsubsection{Embriogênese zigótica}

Foram utilizados embriões zigóticos imaturos e maturos de $A$. angustifolia, coletados no Parque Estadual de Campos do Jordão, localizado no município de Campos do Jordão, Estado de São Paulo. Para a realização das coletas foram selecionadas três árvores (identificadas como árvores $\mathrm{A}, \mathrm{B}$ e $\mathrm{C}$ ), sendo que de cada árvore foram retiradas três pinhas por coleta (total de nove pinhas). Ao todo foram realizadas três coletas (junho de 2012, dezembro de 2012 e março de 2013), de cones contendo embriões zigóticos correspondendo a diferentes fases do desenvolvimento embrionário: a) embriogênese inicial, b) embriogênese tardia e c) embrião maturo (Figura 1: A, B e C).

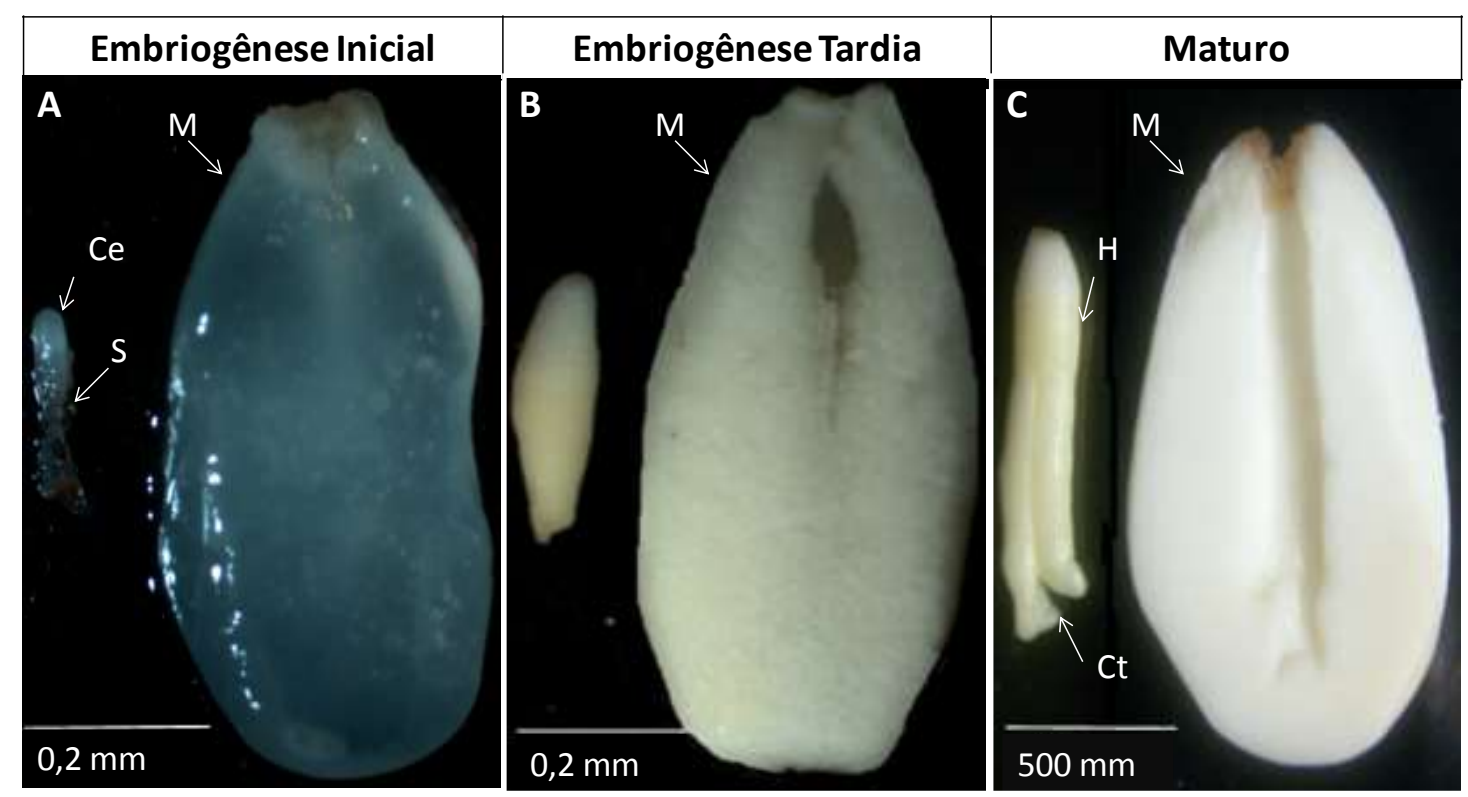

Figura 1. Fases do desenvolvimento embrionário zigótico de $A$. angustifolia. $(\mathrm{A})$ embriogênese inicial; (B) embriogênese tardia e (C) embrião maturo. Cabeça embrionária (Ce), sistema suspensor (S), megagametófito $(M)$, cotilédone $(\mathrm{Ct})$ e hipocótilo $(\mathrm{H})$.

\subsubsection{Embriogênese somática}

\subsubsection{Indução de culturas embriogênicas}

Sementes imaturas de $A$. angustifolia foram imersas por 2 minutos em etanol $70 \%(\mathrm{v} / \mathrm{v})$ e posteriormente por 30 minutos em solução $20 \%(\mathrm{v} / \mathrm{v})$ de hipoclorito de 
sódio ( $2 \%(\mathrm{p} / \mathrm{v})$ cloro ativo). Após três lavagens com água destilada autoclavada, os embriões zigóticos foram isolados em câmara de fluxo laminar. Os embriões zigóticos em fase de embriogênese inicial (Figura 1A) foram inoculados em placas de Petri (100 x $15 \mathrm{~mm}$ ) contendo $25 \mathrm{~mL}$ de meio de cultura basal MSG (Becwar et al., 1990) solidificado com Gelrite (Sigma $\left.{ }^{\circledR}\right)$, suplementado com sacarose (3\% p/v), acrescido de 20 mM de MES (Sigma® ácido 2-(n-morfolino) etano sulfônico) e ácido salicílico (AS) (Sigma®) em concentrações de 0, 0,1, 0,5, 1 e $2 \mathrm{mM}$, dissolvido em etanol. O pH foi ajustado para 5,8 e o meio autoclavado, por 15 minutos, à temperatura de $121^{\circ} \mathrm{C}$ e 1,5 atm. Após a autoclavagem a L-glutamina $\left(1,46 \mathrm{~g}^{/ L}\right)$ foi adicionada por filtroesterilização. As placas de Petri, em número de 90, cada uma contendo cinco embriões zigóticos imaturos (90 embriões por tratamento), foram incubadas no escuro a uma temperatura de $25 \pm 2^{\circ} \mathrm{C}$. Após um período de 45 dias, utilizando uma lupa (SteREO Discovery. V8 Zeiss) acoplada a uma câmera AxioCam 13 Icc1 (Zeiss) foi realizada a contagem do número de embriões zigóticos apresentando a proliferação de massa celular branco translúcida, característica de culturas embriogênicas de coníferas. Explantes que apresentaram estas características foram considerados induzidos.

\subsubsection{Proliferação e manutenção de linhagens embriogênicas estabelecidas}

Para os experimentos envolvendo a embriogênese somática foram utilizadas duas linhagens celulares embriogênicas (identificadas como 01 e 06) previamente estabelecidas no BIOCEL por Jo et al. (2012). Estas linhagens foram induzidas em dezembro de 2009 de acordo com dos Santos et al. (2008). Foram utilizados embriões zigóticos imaturos (Figura 1A) inoculados em meio de cultura MSG (Becwar et al., 1990), suplementado com 3\% (p/v) sacarose, 1,46 g/L de L-glutamina, e 0,3\% (p/v) de Gelrite $^{\circledR}$ (Sigma). Após seis meses em meio de proliferação, as linhagens celulares 01 e 06 (Figura 2A e B) foram testadas em meio de maturação (meio MSG suplementado com 7\% (p/v) maltose, 9\% (p/v) PEG 4000 e $120 \mu \mathrm{M}$ de ácido abscísico) com o objetivo de determinar o seu potencial embriogenênico. Estas linhagens embriogênicas vêm sendo proliferadas e mantidas no escuro à temperatura de $25 \pm 2^{\circ} \mathrm{C}$. O material é subcultivado em intervalos de três semanas em meio de cultura MSG suplementado com $3 \%(\mathrm{p} / \mathrm{v})$ sacarose, $1,46 \mathrm{~g}^{\mathrm{L}}$ de L-glutamina e 0,3\% de Gelrite® (Sigma). 

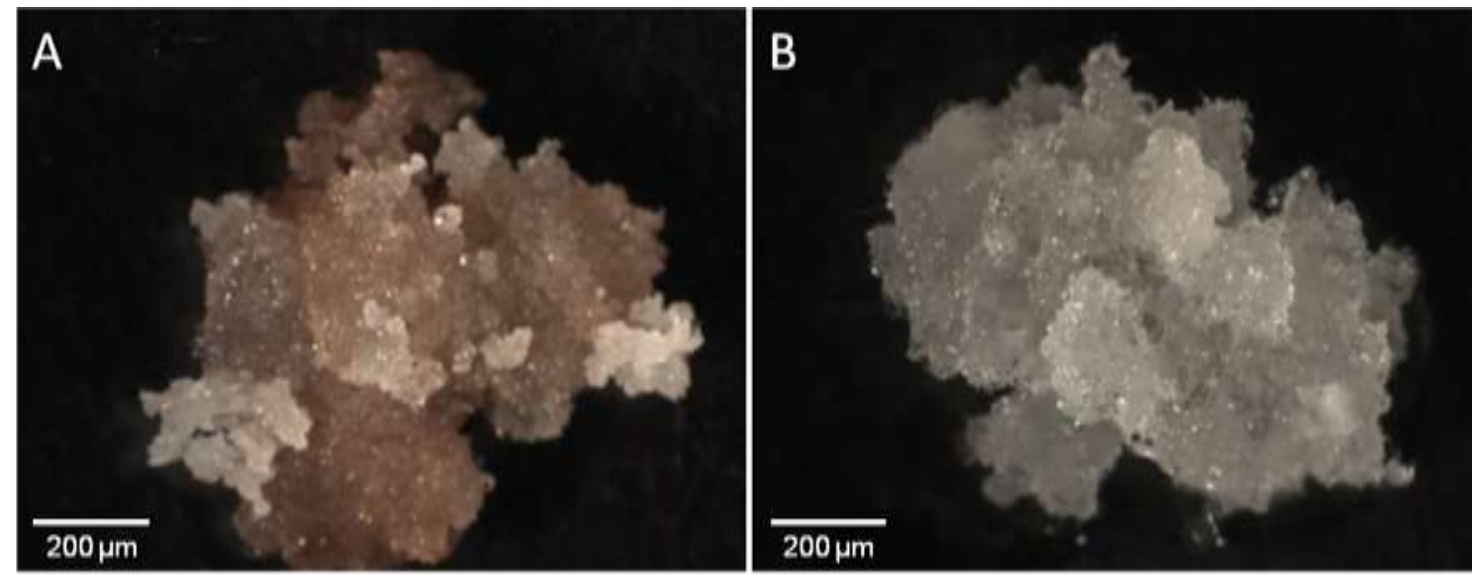

Figura 2. Aspecto morfológico das linhagens celulares embriogênicas de $A$. angustifolia durante a fase de proliferação em meio de cultura MSG. (A) linhagem celular 01; (B) linhagem celular 06.

\subsubsection{Estabelecimento das suspensões celulares}

A partir das duas linhagens celulares estabelecidas por Jo et al. (2012) e mantidas no BIOCEL (item 3.1.2.2.), foram obtidas as suspensões celulares conforme descrito por dos Santos et al. (2008). Inicialmente o material foi repicado para placas de Petri contendo meio de cultura semi- sólido e isento de fitorreguladores (MSG0), e subcultivado durante 21 dias, no escuro, à temperatura de $25 \pm 2^{\circ} \mathrm{C}$. Como inóculo inicial utilizou-se $500 \mathrm{mg}$ (massa fresca) das culturas embriogênicas, os quais foram dissociados com o auxílio de uma pinça e transferidos para frascos de $100 \mathrm{ml}$ contendo $20 \mathrm{ml}$ de meio líquido MSG0. Após 14 dias de cultivo, em um agitador orbital (rotação de $120 \mathrm{rpm}$ ), no escuro, à temperatura de $25 \pm 2{ }^{\circ} \mathrm{C}, 4 \mathrm{~mL}$ das suspensões celulares formadas foram transferidas para frascos de $200 \mathrm{ml}$ contendo $50 \mathrm{ml}$ de meio MSG0. Após três ciclos de subcultivo nos frascos de $50 \mathrm{ml}$ (repicagem a cada 12 dias), as suspensões celulares foram consideradas estabelecidas.

\subsection{Avaliação do crescimento}

\subsubsection{Culturas embriogênicas}

O crescimento foi avaliado por determinação de matéria fresca. Cinco inóculos contendo aproximadamente $100 \mathrm{mg}$ de calo provenientes das linhagens 01 e 06, foram cultivados por 21 dias em cada placa de Petri (total de três por tratamento), contendo meio MSG acrescido de 20 mM de MES (Sigma® ácido 2-(n-morfolino) etano sulfônico) ( $\mathrm{pH} 5,8)$ suplementado com diferentes concentrações de $A S(0,0,1$, 
$0,5,1$ e $2 \mathrm{mM}$ ), no escuro à temperatura de $25 \pm 2^{\circ} \mathrm{C}$. Após este período, os calos foram isolados e pesados utilizando-se uma balança analítica (Mettler Toledo AB204).

\subsubsection{Suspensões celulares}

O estudo da dinâmica de crescimento das suspensões celulares das linhagens 01 e 06 foi realizado pela determinação da massa celular sedimentada (Osti et al., 2010), utilizando-se frascos Erlenmeyer de $125 \mathrm{~mL}$ adaptados com tubos de ensaio (Figura 3A-B). Para determinação da massa celular sedimentada foi utilizado um paquímetro, sendo as leituras realizadas em intervalos de dois dias (20 dias no total).
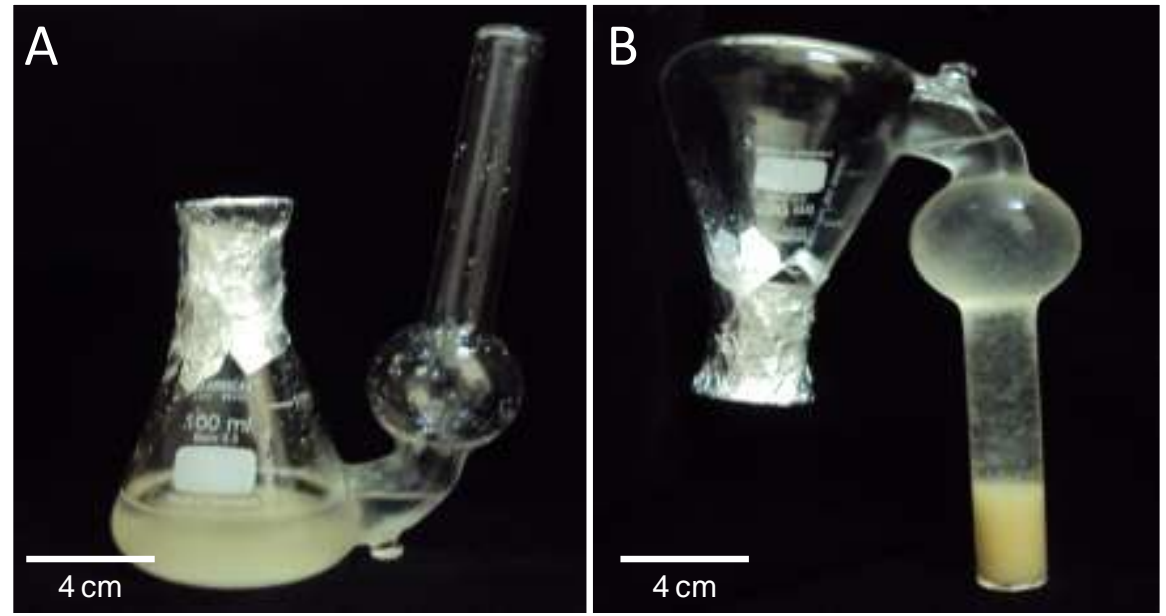

Figura 3. Frascos utilizados para a determinação da massa celular sedimentada de linhagens celulares de $A$. angustifolia. (A) posição do frasco durante o período de cultivo das linhagens e (B) posição invertida para determinação da massa celular sedimentada.

\subsection{Determinações bioquímicas}

\subsection{1. Ácido salicílico livre e conjugado}

\subsubsection{Extração do ácido salicílico (AS) livre e conjugado}

A metodologia para extração e dosagem do AS foi baseada na técnica descrita por Verberne et al. (2002). Para isto, 0,5 g (peso fresco) dos embriões zigóticos em diferentes estádios de desenvolvimento (Figura 1) e das culturas embriogênicas (Figura 2), foram trituradas em nitrogênio líquido e transferidas para tubos plásticos de $2 \mathrm{~mL}$. Após a adição de $1 \mathrm{~mL}$ de 90\% (v/v) de metanol e o padrão interno 3,4 ácido dihidróxibenzóico (DHBA) (15 $\mu \mathrm{M})$, o material pulverizado foi homogeneizado por agitação e em seguida sonicado por 5 min. Após esta etapa o material foi centrifugado 
(14.000 rpm, $20^{\circ} \mathrm{C}, 5 \mathrm{~min}$ ), sendo o sobrenadante coletado (sobrenadante 1) e o precipitado ressuspendido em $0,5 \mathrm{ml}$ de metanol $100 \%$ para re-extração do material (sobrenadante 2).

Após a reunião dos sobrenadantes 1 e 2 em um único tubo, foram adicionados $10 \mu \mathrm{L}$ de $\mathrm{NaOH}(0,2 \mathrm{M})$. As amostras foram evaporadas até aproximadamente $50 \mu \mathrm{L}$ utilizando um concentrador SpeedVac em temperatura ambiente, sendo em seguida ressuspendida em solução $5 \%(\mathrm{p} / \mathrm{v})$ de ácido tricloroacético (TCA). A solução formada foi então particionada utilizando uma solução de acetato etílico: cilohexano (proporção 1:1), resultando em uma fase superior contendo solvente orgânico (AS livre) e uma fase inferior aquosa contendo 2-O- $\beta$-D-glicosídeo (AS conjugado). O processo de particionamento foi realizado duas vezes, sendo as amostras das fases superiores (AS livre) combinadas e posteriormente concentradas em um Speedvac. A fase aquosa (contendo SAG) foi submetida à hidrólise ácida com a adição de solução $8 \mathrm{~N}$ de HCL seguida de incubação a $80^{\circ} \mathrm{C}$ por 60 min (Meuwly \& Métraux, 1993). A solução resultante foi particionada utilizando a mistura de acetato etílico: cilohexano conforme já descrito anteriormente, sendo o AS conjugado liberado para a sua forma livre. Após a evaporação da fase líquida utilizando Speedvac em temperatura ambiente, as amostras contendo o AS livre e AS conjugado (2-O- $\beta$-D-glicosídeo, SAG) foram ressuspendidos em solução de metanol $100 \%$.

\subsubsection{Quantificação do AS livre e conjugado}

A quantificação de AS livre e conjugado foi realizada por CLAE utilizando coluna C18 fase reversa (Sigma-Aldrich - Supelcosil-LC18). Como fase móvel utilizouse as soluções de metanol $75 \%$ em água acidificada com $0,5 \%$ de ácido acético glacial (solução A) e metanol 100\% (solução B). O programa de eluição da fase móvel iniciou com $25 \%$ da solução $B$ por 3 minutos, sendo que após esse tempo foi aumentado o gradiente para $60 \%$ da solução B por 6 minutos. Em seguida a eluição transcorreu por mais 3 minutos em $100 \%$ da solução $B$, retornando a concentração inicial, o que resultou em um tempo total de corrida de 15 minutos com fluxo de $1 \mathrm{~mL} \cdot \mathrm{min}^{-1}$, a $40 \stackrel{\circ}{\circ}$. O detector de fluorescência foi ajustado com o comprimento de onda de excitação a $295 \mathrm{~nm}$ e emissão a $412 \mathrm{~nm}$. O volume de amostra injetado foi de $20 \mu \mathrm{L}$. A identificação e quantificação do ácido salicílico nas amostras foram feitas por comparação com as áreas e tempos de retenção de uma curva padrão, com concentrações conhecidas de AS. 


\subsubsection{Quantificação e visualização do óxido nítrico (NO) e espécies reativas de oxigênio (ERO)}

A quantificação e visualização do NO e ERO foi realizada de acordo com as metodologias descritas por Silveira et al. (2006) e Laxalt et al. (2007), por três vezes em cada linhagem, nos materiais obtidos segundo o item. 3.1.2.3. Ao término do décimo primeiro dia de cultivo, as suspensões celulares das linhagens 01 e 06 foram filtradas em peneiras de dissociação celular $\left(\right.$ Sigma $^{\circledR}$ S-1145, malha de $100 \mu \mathrm{m}$ ). Quatro $\mathrm{mL}$ da fração celular menor que $100 \mu \mathrm{m}$ foram transferidos para frascos contendo $50 \mathrm{~mL}$ de meio MSG0, e subcultivadas por mais 10 dias. Ao término deste período, alíquotas contendo $60 \mathrm{mg}$ de células (peso fresco) foram transferidas para placas de BIOFIL® (96 poços) contendo $1 \mathrm{~mL}$ de meio MSG0 acrescido de $20 \mathrm{mM}$ de MES (Sigma® ácido 2-(n-morfolino) etano sulfônico) (pH 5,8). Após 30 min no escuro sob agitação de $60 \mathrm{rpm}$, foram aplicados nos poços diferentes concentrações de AS $(0,0,1,0,5,1$ e $2 \mathrm{mM})$. Imediatamente após a adição do ácido salicilico foram adicionados 2,5 $\mu \mathrm{M}$ /poço do fluoróforo DAR- 4M (Diaminorhodamina 4M, Alexis ${ }^{\circledR}$ ) (quantificação do NO extracelular), $5 \mu \mathrm{M} /$ poço de DAR 4M AM (Diaminorhodamina 4M acetoxymethyl, Alexis ${ }^{\circledR}$ ) (quantificação do $\mathrm{NO}$ intracelular), ou $25 \mu \mathrm{M} /$ poço de $\mathrm{H}_{2}$ DCFDA (2',7'-dichlorodihydrofluoresceína diacetato, Alexis ${ }^{\circledR}$ ) (quantificação de ERO extracelular). A fluorescência foi determinada utilizando-se um fluorômetro (Victor 3TM- Perkin Elmer), com comprimentos de onda de excitação $560 \mathrm{~nm}$ e emissão a $575 \mathrm{~nm}$ para o NO (intra- e extracelular) e excitação de $502 \mathrm{~nm}$ e emissão de $523 \mathrm{~nm}$ para as ERO. As placas de 96 poços contendo as suspensões celulares suplementadas com o AS foram monitoradas para emissão da fluorescência por três horas (medições a cada 10 min.) no escuro, sob agitação de 125 rpm.

As análises de microscopia de fluorescência foram realizadas retirando-se 90 $\mu \mathrm{L}$ das suspensões suplementadas com $2 \mathrm{mM}$ de AS (30 min após a adição do AS). Em seguida foram obtidas lâminas (três por tratamento), sendo o material analisado utilizando-se microscópio de fluorescência Axio Imager M2 (Zeiss), com o programa Axio Vision Rel. 4.8 (Zeiss) e fotografado com câmera Axio Cam MR3 (Zeiss), obtendo-se imagens de campo claro e de fluorescência. O filtro utilizado para o reagente DAR 4M AM (diaminorhodamine-4M acetoxymethyl ester),foi de excitação 546/12 e emissão 575-640. Para o reagente $\mathrm{H}_{2}$ DCFDA (2,7-dichlorodihydrofluorescein diacetate), o filtro de excitação foi de 500/20 e emissão 535/30. A metodologia utilizada para a quantificação e visualização de NO e ERO nas linhagens celulares está representado na figura 4. 


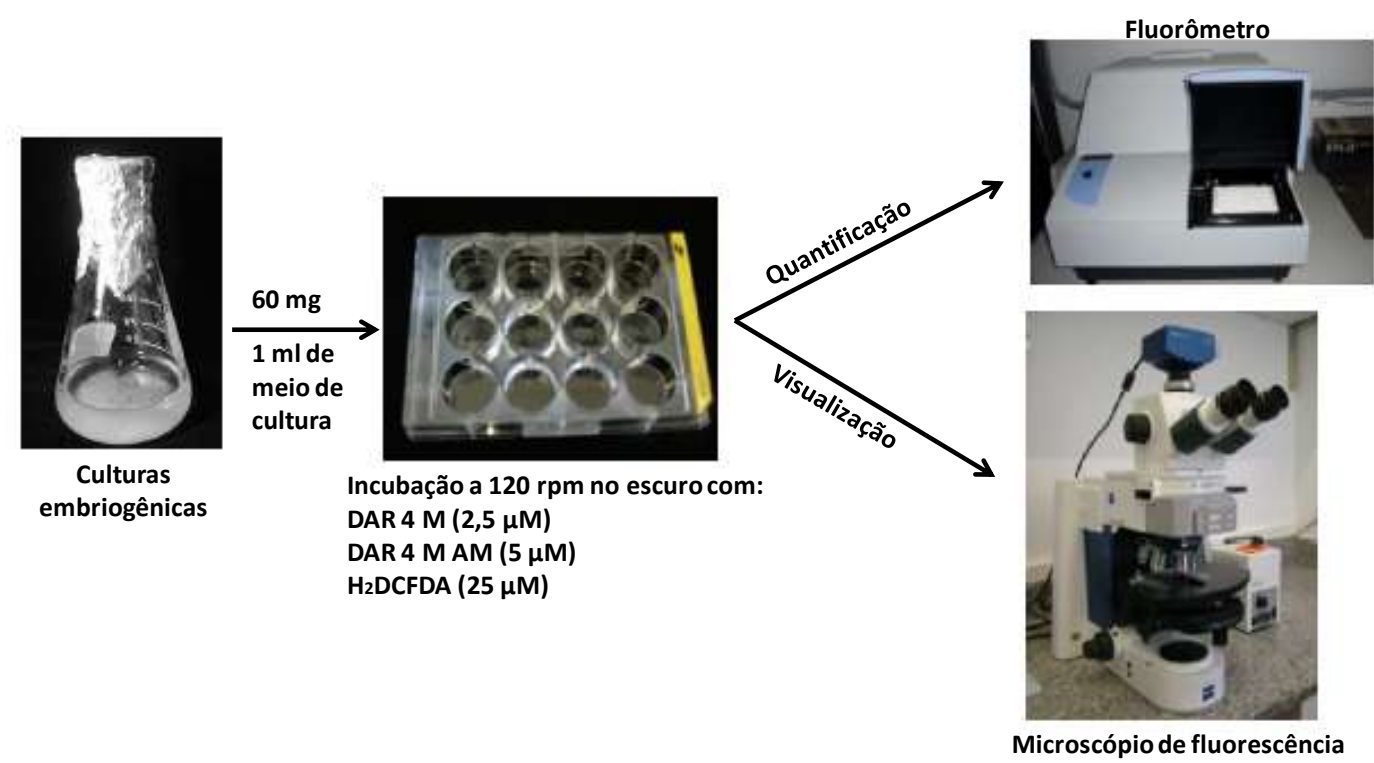

Figura 4 - Metodologia utilizada para quantificação e visualização de NO e ERO em linhagens celulares de $A$. angustifolia cultivadas na presença de diferentes concentrações de ácido salicílico $(0-2 \mathrm{mM})$.

\subsubsection{Efeito do doador, sequestrador e inibidor da síntese de NO sobre o conteúdo endógeno de NO e ERO}

Para as análises, foram incorporados ao meio de cultura $1 \mathrm{mM}$ (Anexo I) das seguintes substancias: um doador de NO, o S-Nitrosoglutathiona (GSNO); um seqüestrador de NO, o 2-phenyl-4,4,5,5-tetramethylimidazoline-1,1-oxyl-3-oxide (PTIO); e um inibidor da enzima óxido nítrico sintase (NOS), o NG-nitro-L-arginine methyl ester (L-NAME). $\mathrm{O}$ pH do meio de cultura foi ajustado para 5,8 após ser suplementado com $20 \mathrm{mM}$ de MES antes da autoclavagem, a $121^{\circ} \mathrm{C}$, e $1,5 \mathrm{~atm}$ durante $15 \mathrm{~min}$. Após a autoclavagem, foram adicionados ao meio de cultura o GSNO, PTIO, L-NAME junto ao AS em diferentes concentrações (0, 0,5 e $2 \mathrm{mM})$, por filtro esterilização (membrana de 0,22 um), em câmara de fluxo laminar. As suspensões celulares foram cultivadas em placas de cultura de seis poços e após 1h de incubação, foram analisados os conteúdos de NO intra e extracelular e ERO intracelular conforme metodologia descrita no item 3.3.2. 


\section{4. Avaliações morfológicas}

Durante os diferentes tratamentos de suplementação com 0 AS 0 desenvolvimento dos embriões somáticos foi monitorado por meio de testes histoquímicos, utilizando a dupla-coloração com carmin acético $2 \%(\mathrm{p} / \mathrm{v})$ e azul de Evans $0,1 \%(p / v)$ (Gupta \& Durzan, 1987). As amostras coradas foram observadas e fotografadas em um microscópio óptico Axiolmager.M2 equipado com câmera digital (Zeiss $\left.{ }^{\circledR}\right)$. As linhagens celulares foram avaliadas com relação a sua coloração para formação de embriões somáticos e fotografadas em lupa SteREO Discovery.V8 (Carl Zeiss ${ }^{\circledR}$ ) acoplada a uma máquina fotográfica AxioCam ICC 1 (Carl Zeiss ${ }^{\circledR}$ ).

\subsection{Expressão do gene AaSERK}

\subsubsection{Extração de RNA e síntese de cDNA}

Culturas celulares das linhagens 01 e 06 congeladas a $-80^{\circ} \mathrm{C}$ foram processadas em nitrogênio líquido e alíquotas de $300 \mathrm{mg}$ de tecido triturado por placa foram submetidos à extração de RNA total empregando-se o reagente Trizol (Life Technologies), segundo o protocolo recomendado pelo fabricante. As amostras de RNA foram ressuspendidas em $20 \mu \mathrm{L}$ de água DEPC 0,1\%. A quantidade, pureza e integridade do RNA total extraído foram estimadas por espectrofotômetro Nanodrop® (ND-100, Technologies) e por eletroforese em gel de agarose $1 \%$. Amostras de alta qualidade com razão de OD maior ou igual a 1,8 (260/280 nm) e 1,9 (260/230 nm) foram selecionadas. Para remover potenciais traços contaminantes de DNA genômico, $2 \mu \mathrm{g}$ de cada amostra de RNA foi submetido a tratamento com DNAse I (Life Technologies). O RNA tratado foi reverso transcrito utilizando-se random primers como iniciadores e o kit SuperScript ${ }^{\circledR}$ III Reverse Transcriptase (Life Technologies), de acordo com as recomendações do fabricante. A ausência de contaminação de DNA genômico foi avaliada por meio de PCR, utilizando-se iniciadores do gene da

Ubiquitina (Foward: 5'-CCTCGTGTCGATTTACGTC-3', Reverse: 5'GGGCGGCTTCTGGATTTG-3') que se anelam em éxons diferentes do gene. Dessa forma, o tamanho do fragmento amplificado a partir de DNA genômico corresponderia a 723pb e de cDNA a $181 \mathrm{pb}$. As reações de PCR foram conduzidas empregando-se tampão 1X, $0.2 \mathrm{mM}$ de cada dNTPs, $200 \mathrm{nM}$ de cada iniciador, $50 \mathrm{ng}$ de cDNA e $1 \mathrm{U}$ de enzima Taq polimerase (Life Technologies). As condições de amplificação utilizadas foram de $94{ }^{\circ} \mathrm{C}$ por $10 \mathrm{~min} ; 35$ ciclos de 30 s a $94{ }^{\circ} \mathrm{C}, 30$ s a $60 \stackrel{\circ}{\circ} \mathrm{C}, 1$ min a 72 oC; uma extensão final a $72 \stackrel{\circ}{\circ}$ por $10 \mathrm{~min}$. Os produtos de amplificação foram 
visualizados em gel de agarose 1,2\%. Por fim, as amostras de cDNA foram diluídas na proporção 1:10, obtendo-se a concentração final de 5 ng de RNA reverso-transcrito/ $\mu$ l.

\subsubsection{Iniciadores}

O desenho dos iniciadores dos genes de interesse foi realizado sobre as sequências de AaSERK (Somatic Embryogenesis Receptor Kinase) e AaEF (Elongation fator) obtidas através do da plataforma do Transcriptoma de A. angustifolia utilizando o programa BLAST (Elbl et al., 2014). Foram desenhados dois pares de oligonucleotideos (Tabela 1) através do programa Oligo Perfect 3.1 (http://tools.lifetechnologies.com). Os iniciadores foram testados utilizando o pool do cDNA de amostras das linhagens 01 e 06. Para cada reação de PCR de $25 \mu \mathrm{L}$, utilizou-se $1 \mathrm{uL}$ de cDNA (1:10), 0,2 $\mu \mathrm{L}$ de Taq polimerase (Invitrogen), 200 pmoles de cada dNTP, 200 pmoles de cada primer, $5 \mu \mathrm{L}$ do Tampão 10x (300 mM Tris-SO4, 90 $\mathrm{mM}(\mathrm{NH} 4) 2 \mathrm{SO} 4$ e $5 \mathrm{mM} \mathrm{MgSO} 4)$ e $0,75 \mu \mathrm{L}$ de $\mathrm{MgCl}$ atingindo uma concentração final de 1,5 mM. A reação foi processada em termociclador (Veriti, Applied Biosystems) por 35 ciclos que correspondem à desnaturação a $94^{\circ} \mathrm{C}$ por $30 \mathrm{~s}, 60{ }^{\circ} \mathrm{C}$ anelamento por $30 \mathrm{~s}$, extensão a $72^{\circ} \mathrm{C}$ por 5 a 7 min.

Tabela.1. Iniciadores utilizados para reações de qPCR dos genes AaSERK e $A a E F$.

\begin{tabular}{|c|c|c|c|}
\hline Gene & & & Amplicon \\
\hline AaEF & $\mathrm{F}$ & 5'-GAGAGGCTTGTCTGTAGGACGC-3' & \multirow{2}{*}{$230 \mathrm{pb}$} \\
\hline AaEF & $\mathrm{R}$ & 5'-CCACTCCCAAGTATTCAAAAGGTCG-3' & \\
\hline AaSERK & $\mathrm{F}$ & 5'-GAATATGAGGCAGTGGTGGG-3' & \multirow{2}{*}{$205 \mathrm{pb}$} \\
\hline AaSERK & $\mathrm{R}$ & 5'-GCCCGTTGTCCCGTAATAAG-3' & \\
\hline Ubi & $\mathrm{F}$ & 5'-CCTCGTGTCGATTTACGTC-3' & \multirow{2}{*}{$181 \mathrm{pb}$} \\
\hline Ubi & $\mathrm{R}$ & 5'-GGGCGGCTTCTGGATTTG-3' & \\
\hline
\end{tabular}




\subsection{3. qPCR}

A reação de qPCR foi realizada com $4 \mu \mathrm{l}$ de uma diluição de cDNA 1:10, 0,4 $\mathrm{mM}$ de cada iniciador e 2x SYBR Green Master Mix (Qiagen), utilizando o termociclador 7300 PCR Real Time (Applied Biosystems), seguindo o programa de amplificação de $95{ }^{\circ} \mathrm{C}$ por 10 min e 40 ciclos de: $95^{\circ} \mathrm{C}$ por $15 \mathrm{seg}, 60^{\circ} \mathrm{C}$ por 1 min e $72 \stackrel{\circ}{ } \mathrm{C}$ por $30 \mathrm{~s}$ (momento no qual ocorre a leitura do sinal emitido pelo SYBR Green). A normalização da expressão gênica foi calculada a partir do método $\Delta \Delta \mathrm{Ct}$ com as modificações propostas por Hellemans et al. (2007). O Ct e a eficiência média da qPCR, baseada na fase O gene ELONGATION FACTOR (AaEF) foi utilizado como gene constitutivo. Os valores de "cycle threshold" (Ct) e a eficiência de reação de cada iniciador foram determinados através do software LinRegPCR (Rujiter et al., 2009). Utilizou-se o software fgStatistics (Di Rienzo, 2009) para cálculo da expressão relativa.

\subsection{Análises estatísticas}

Todos os dados utilizados nos resultados foram obtidos em triplicata. Como estatística, os dados foram submetidos à análise de variância (ANOVA) e ao Teste de Separação de Médias de Tukey $(\mathrm{P}<0,01)$, quando necessário, foi aplicado o teste de T Student, usando o programa BioEstat 5.0 desenvolvido pelo Instituto Mamirauá. 0 erro padrão foi calculado utilizando-se o programa Excel 2003.

\subsection{Delineamento experimental}

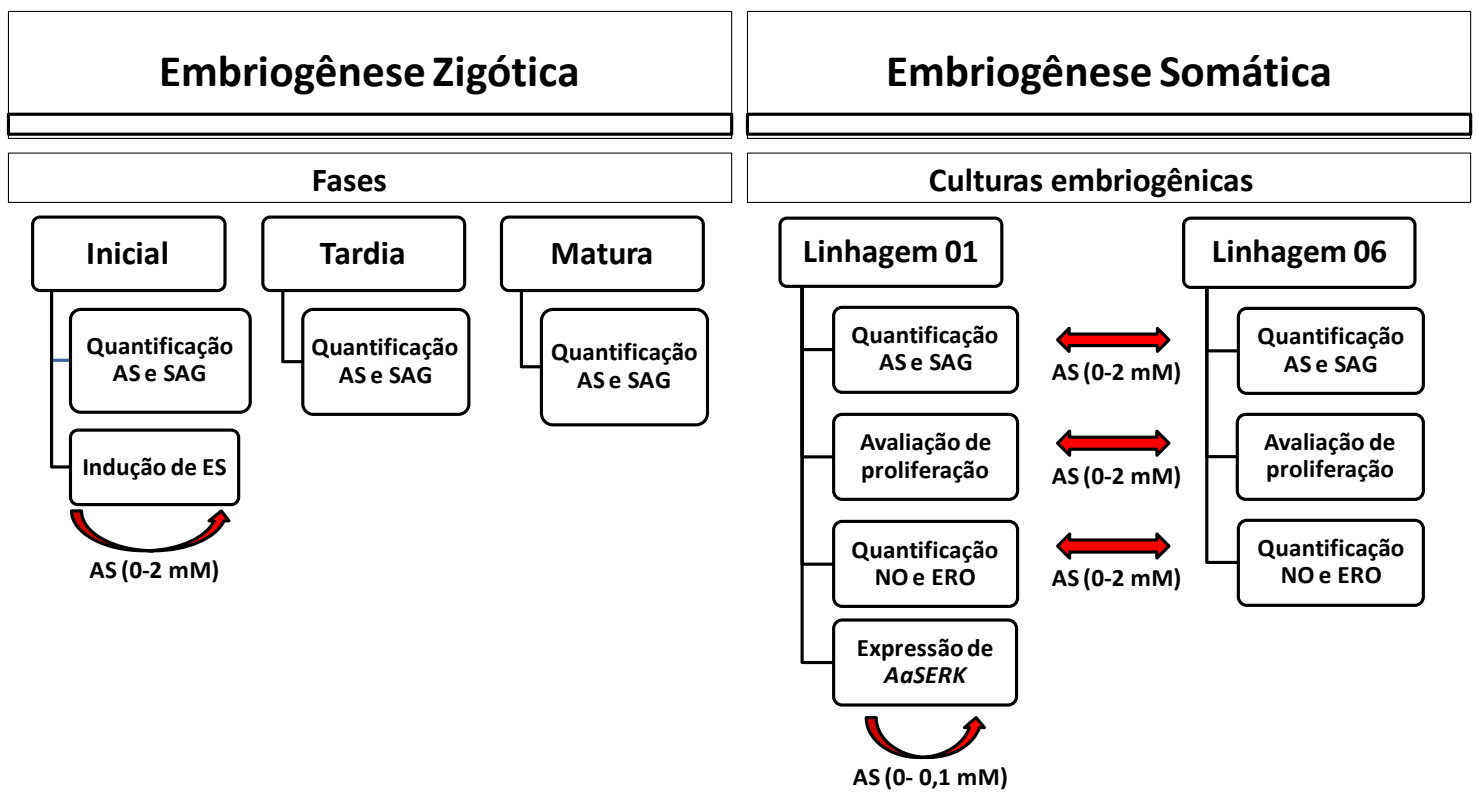




\section{RESULTADOS}

\subsection{Embriogênese zigótica}

\subsubsection{Conteúdo de AS e SAG em embriões zigóticos}

O conteúdo de AS, livre e conjugado foi avaliado nos embriões zigóticos e seus respectivos megagametófitos nas três fases de desenvolvimento (Tabela 2).

Observou-se que:

a) o conteúdo de AS nos embriões zigóticos apresentou diferenças significativas ( $p \leq$ $0,01)$, com valores mais elevados na embriogênese inicial, seguida pela matura e por último pela tardia;

b) a forma conjugada (SAG), também apresentou maiores valores na fase inicial, decrescendo gradualmente nas duas fases posteriores. Ressalta-se que os valores de AS observados foram superiores aos do SAG, em todas as fases de desenvolvimento;

c) no megagametófito, os maiores valores de AS foram observados na etapa de embriogênese tardia, seguida pela embriogênese inicial. $O$ menor conteúdo ocorreu quando do megagametófito maturo;

d) os valores de SAG demonstram um maior acúmulo no megagametófito maturo, seguido pela embriogênese tardia e por último pela embriogênese inicial.

Tabela 2. Conteúdo ( $\mu \mathrm{g} / \mathrm{g}$ de massa fresca) de ácido salicílico livre (AS) e conjugado (SAG) em embriões zigóticos e seus megagametófitos (Mega) nas diferentes fases de desenvolvimento (embriogênese inicial, tardia e matura). Média \pm desvio padrão, $n=3$.

\begin{tabular}{|c|c|c|c|c|c|c|}
\hline \multirow{3}{*}{$\begin{array}{c}\text { Conteúdo } \\
(\mu \mathrm{g} / \mathrm{g} \text { de MF) }\end{array}$} & \multicolumn{6}{|c|}{ Estádios da embriogênese zigótica } \\
\hline & \multicolumn{2}{|c|}{ Inicial } & \multicolumn{2}{|c|}{ Tardia } & \multicolumn{2}{|c|}{ Matura } \\
\hline & Mega & Embrião & Mega & Embrião & Mega & Embrião \\
\hline AS & $0.057 \pm 0.09$ & $0.129 \pm 0.14$ & $0.092 \pm 0.09$ & $0.060 \pm 0.13$ & $0.034 \pm 0.11$ & $0.078 \pm 0.14$ \\
\hline SAG & $0.001 \pm 0.10$ & $0.024 \pm 0.12$ & $0.003 \pm 0.13$ & $0.019 \pm 0.11$ & $0.005 \pm 0.09$ & $0.017 \pm 0.06$ \\
\hline
\end{tabular}




\subsection{Embriogênese somática}

\subsubsection{Indução de culturas embriogênicas em meio de cultura suplementado com diferentes concentrações de AS}

A suplementação do meio de cultura com diferentes concentrações de AS não promoveu a indução de culturas embriogênicas em $A$. angustifolia. A figura 5 apresenta o aspecto morfológico dos embriões zigóticos imaturos cultivados nos diferentes tratamentos.

Observou-se que:

a) ocorre a proliferação de uma massa mucilaginosa branca-translúcida, característica de materiais induzidos para a embriogênese, apenas nos explantes cultivados no meio controle. Esta resposta foi observada em $5,5 \%$ das culturas;

b) materiais cultivados em meio suplementado com $0,1 \mathrm{mM}$ de $A S$, apresentam intensa oxidação com alteração da estrutura do embrião zigótico inoculado;

c) a adição de 0,5 mM manteve a estrutura embrionária, entretanto, ocorreu uma intensa oxidação na porção da cabeça embrionária;

d) a adição de 1 e $2 \mathrm{mM}$ ao meio de cultura manteve morfologia e coloração similares às observadas na inoculação.

Diante destes resultados, não foi possível prosseguir com a proliferação destas culturas. Assim, para a realização dos estudos posteriores foram utilizadas as culturas embriogênicas estabelecidas no BIOCEL (Item 3.1.2.2.). 


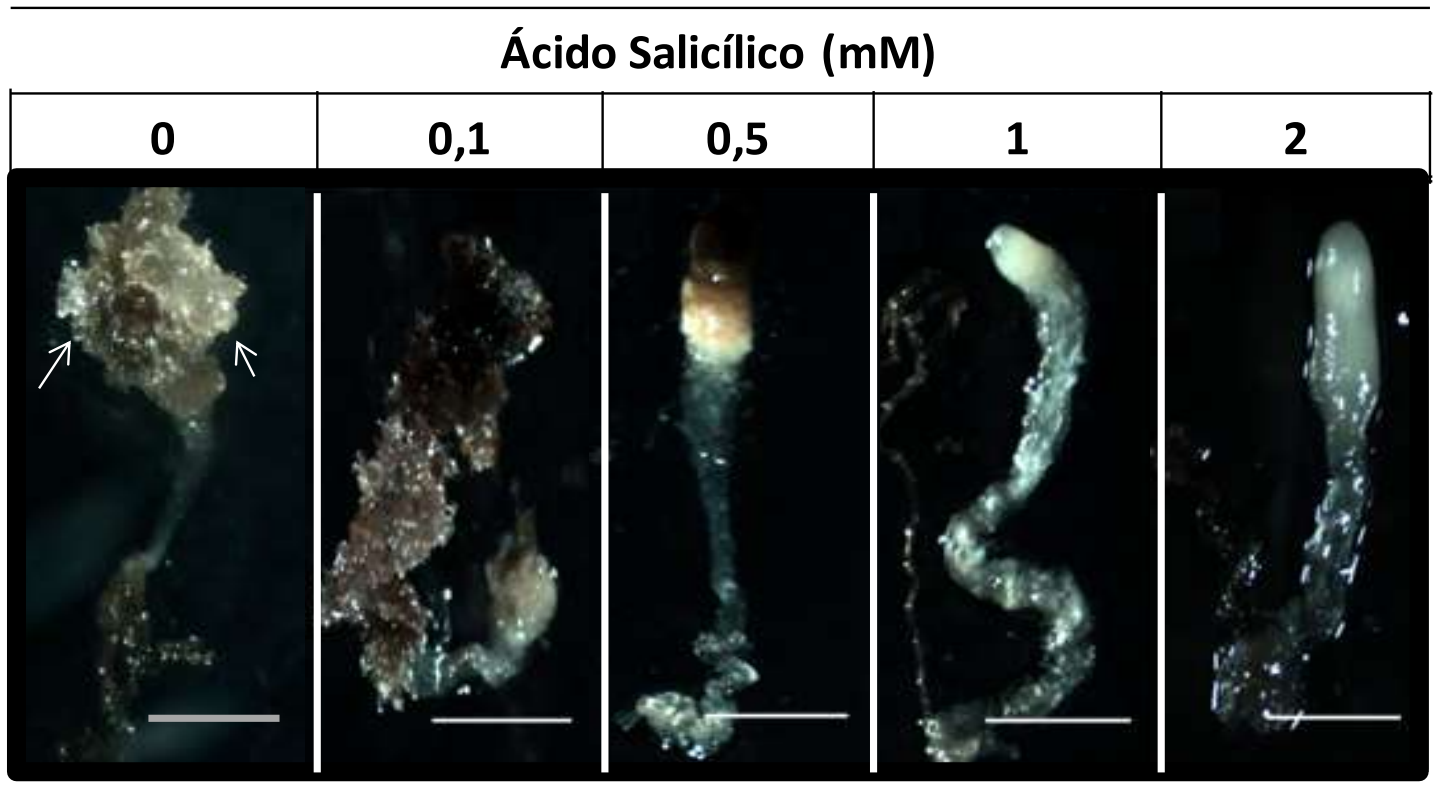

Figura 5. Aspectos morfológicos dos embriões zigóticos imaturos, após 45 dias de cultivo, em meio de cultura MSG suplementado com diferentes concentrações de ácido salicílico (AS). Seta indica calos translúcidos do tratamento controle. Barras $=0,1 \mathrm{~cm}$.

\subsubsection{Linhagens celulares com diferentes potenciais embriogênicos}

\subsubsection{Conteúdo de AS e SAG}

O conteúdo de AS e SAG foi determinado em materiais cultivados em meio suplementado com diferentes concentrações de AS (0, 0,1, 0,5, 1 e $2 \mathrm{mM})$, nas linhagens 01 (Tabela 3) e 06 (Tabela 4).

\section{Observou-se que:}

a) para o material controle (0 mM de AS) os conteúdos de AS e SAG são maiores na linhagem 01 em relação à 06 . Os valores de SAG são superiores aos de AS, independentemente do material;

b) nas linhagens 01 e 06, a suplementação do meio de cultura com AS promoveu um aumento do conteúdo interno de AS livre;

c) na linhagem 01, conteúdos mais elevados e similares de SAG foram observados nos tratamentos contendo 0,1 e $2 \mathrm{mM}$ de AS. Valores menores ocorreram nos tratamentos $1 \mathrm{mM}$, controle e 0,5 mM; 
d) na linhagem 06, o conteúdo de SAG foi similar nos diferentes tratamentos a partir da concentração de $0,5 \mathrm{mM}$. Valores menores foram observados entre o controle e 0,1 $\mathrm{mM}$.

Tabela 3. Conteúdo ( $\mu \mathrm{g} / \mathrm{g}$ de massa fresca) de ácido salicílico livre (AS) e conjugado (SAG) nas culturas da linhagem 01 mantidas em meio suplementado com AS em diferentes concentrações. Média \pm desvio padrão, $n=3$.

\begin{tabular}{c|c|c|c|c|c|}
\hline \multirow{2}{*}{$\begin{array}{c}\text { Conteúdo } \\
(\boldsymbol{\mu g} / \mathbf{g} \text { de MF) }\end{array}$} & $\mathbf{0}$ & $\mathbf{0 , 1}$ & $\mathbf{0 , 5}$ & $\mathbf{1}$ & $\mathbf{2}$ \\
\cline { 2 - 6 } & & & & & \\
\hline \hline AS & $0.48 \pm 0.11$ & $3.40 \pm 0.12$ & $162.34 \pm 0.09$ & $243.47 \pm 0.13$ & $300.80 \pm 0.15$ \\
\hline SAG & $1.33 \pm 0.13$ & $1.45 \pm 0.05$ & $7.78 \pm 0.10$ & $2.60 \pm 0.04$ & $4.24 \pm 0.09$ \\
\hline \hline
\end{tabular}

Tabela 4. Conteúdo ( $\mu \mathrm{g} / \mathrm{g}$ de massa fresca) de ácido salicílico livre (AS) e conjugado (SAG) nas culturas da linhagem 06 mantidas em meio suplementado com AS em diferentes concentrações. Média \pm desvio padrão, $n=3$.

\begin{tabular}{|c|c|c|c|c|c|}
\hline \multirow{2}{*}{$\begin{array}{c}\text { Conteúdo } \\
(\mu \mathrm{g} / \mathrm{g} \text { de MF) }\end{array}$} & \multicolumn{5}{|c|}{ Tratamentos AS (mM) } \\
\hline & 0 & 0,1 & 0,5 & 1 & 2 \\
\hline AS & $0.35 \pm 0.13$ & $1.31 \pm 0.10$ & $139.39 \pm 0.12$ & $264.37 \pm 0.16$ & $325.66 \pm 0.15$ \\
\hline SAG & $1.28 \pm 0.12$ & $1.58 \pm 0.11$ & $6.19 \pm 0.11$ & $1.64 \pm 0.10$ & $1.63 \pm 0.19$ \\
\hline
\end{tabular}

\subsubsection{Crescimento de culturas celulares}

O efeito da suplementação do AS no crescimento das duas linhagens foi analisado nas culturas iniciadas com $0,5 \mathrm{~g}$ após 21 dias de cultivo (Tabela 5).

Observou-se que:

a) materiais cultivados em meio de cultura na presença de AS em concentrações maiores que $0,5 \mathrm{mM}$ não apresentaram crescimento;

b) materiais cultivados na presença de $0,1 \mathrm{mM}$ apresentaram um maior crescimento em relação ao controle. Ressalta-se que os valores obtidos para ambos os tratamentos foram próximos. 
Tabela 5. Crescimento (g) de culturas celulares embriogênicas das linhagens 01 e 06 após 21 dias de incubação em meio suplementado com diferentes concentrações de AS. Média \pm desvio padrão, $\mathrm{n}=3$.

\begin{tabular}{c|c|c}
\hline \multirow{2}{*}{ AS (mM) } & \multicolumn{2}{|c}{ Crescimento (g) } \\
\cline { 2 - 3 } & Linhagem 01 & Linhagem 06 \\
\hline \hline $\mathbf{0}$ & $3,89 \pm 0,013$ & $4,90 \pm 0,011$ \\
\hline $\mathbf{0 , 1}$ & $4,18 \pm 0,011$ & $5,08 \pm 0,014$ \\
\hline $\mathbf{0 , 5}$ & $0,53 \pm 0,011$ & $0,51 \pm 0,012$ \\
\hline $\mathbf{1}$ & $0,50 \pm 0,014$ & $0,50 \pm 0,013$ \\
\hline $\mathbf{2}$ & $0,51 \pm 0,012$ & $0,53 \pm 0,014$ \\
\hline
\end{tabular}

\subsection{Suspensões celulares}

\subsubsection{Dinâmica de crescimento de suspensões celulares}

Nas duas linhagens o padrão de crescimento observado segue uma curva sigmóide (Figura 6).

Observou-se que:

a) após dois dias de cultivo, inicia-se a fase exponencial de crescimento seguida, do quarto e décimo sexto dia, de um crescimento linear;

b) após 18 dias de cultivo, as linhagens atingem a fase estacionária de crescimento;

c) aos 16 dias o comportamento foi diferente, após 11 dias as duas linhagens tendem a atingir a fase estacionária, contudo, a linhagem 06 não acompanha o aumento de biomassa observado para a linhagem 01. 


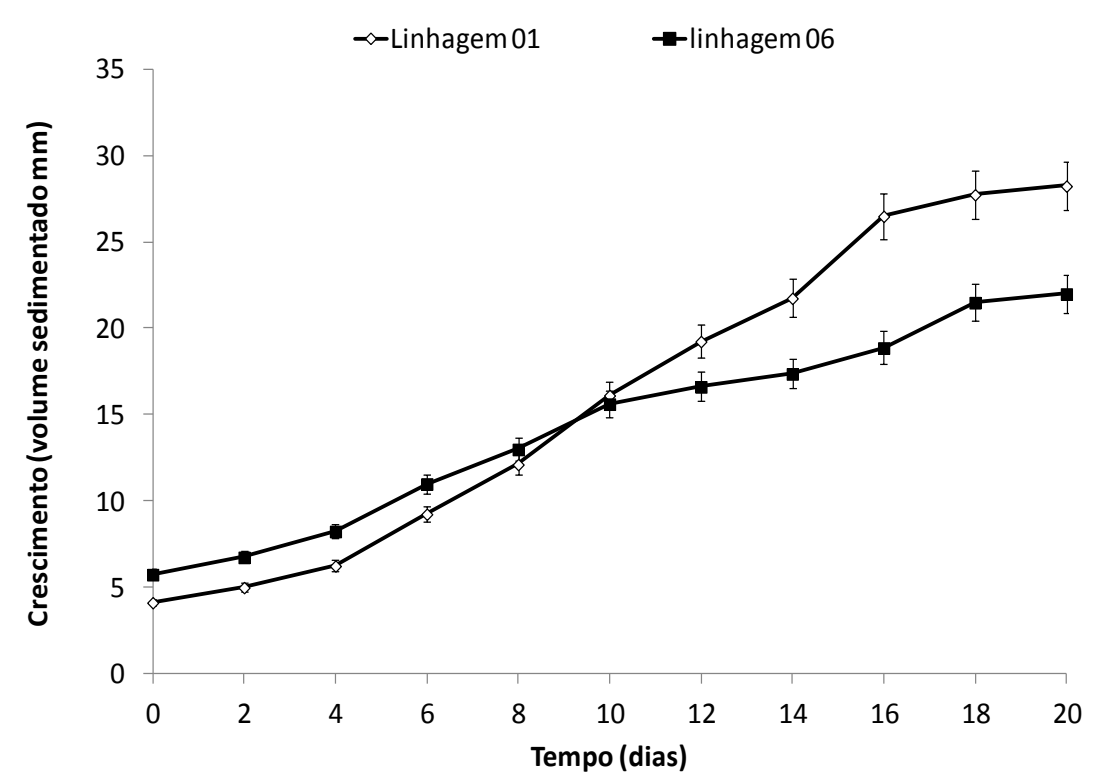

Figura 6. Dinâmica de crescimento das suspensões celulares de $A$. angustifolia, cultivadas em meio MSG durante 20 dias. Média \pm desvio padrão, $n=3$.

\subsubsection{Conteúdo de NO intra e extracelular}

O efeito da adição de AS na produção de NO intra e extracelular foi avaliado nas suspensões celulares das linhagens 01 e 06 (Figura 7).

Observou-se que:

a) as maiores diferenças entre os tratamentos ocorrem no período de $60 \mathrm{~min}$. após a elicitação com AS, após este período ocorreu um declínio e/ou uma estabilização da liberação de NO intra e extracelular com valores similares após 120 min.

b) para a linhagem 01 (Figura 7A) uma maior liberação de NO extracelular ocorre nos tratamentos onde foi adicionado o AS, ao longo de todo o período experimental, os maiores valores foram identificados no tratamento $2 \mathrm{mM}$ e os menores no controle;

c) para a linhagem 06 (Figura 7B), de maneira similar ao observado para a linhagem 01, ocorreu maior liberação de $\mathrm{NO}$ extracelular nos materiais tratados com $2 \mathrm{mM}$ de AS. O tratamento controle apresentou valores superiores aos tratamentos 0,1 e 0,5 $\mathrm{mM}$ e inferiores ao $2 \mathrm{mM}$;

d) a linhagem 01 apresentou queda no conteúdo de NO intracelular nos primeiros 30 min. de avaliação (Figura 7C), passado este período, amostras incubadas com AS apresentaram aumento de NO, os maiores conteúdos foram identificados no tratamento $2 \mathrm{mM}$ e os menores no controle; 
e) a linhagem 06 apresentou conteúdos próximos de NO intracelular até 90 min. de avaliação em todos os tratamentos, após este período, maiores conteúdos de NO foram observados nas amostras incubadas com AS.
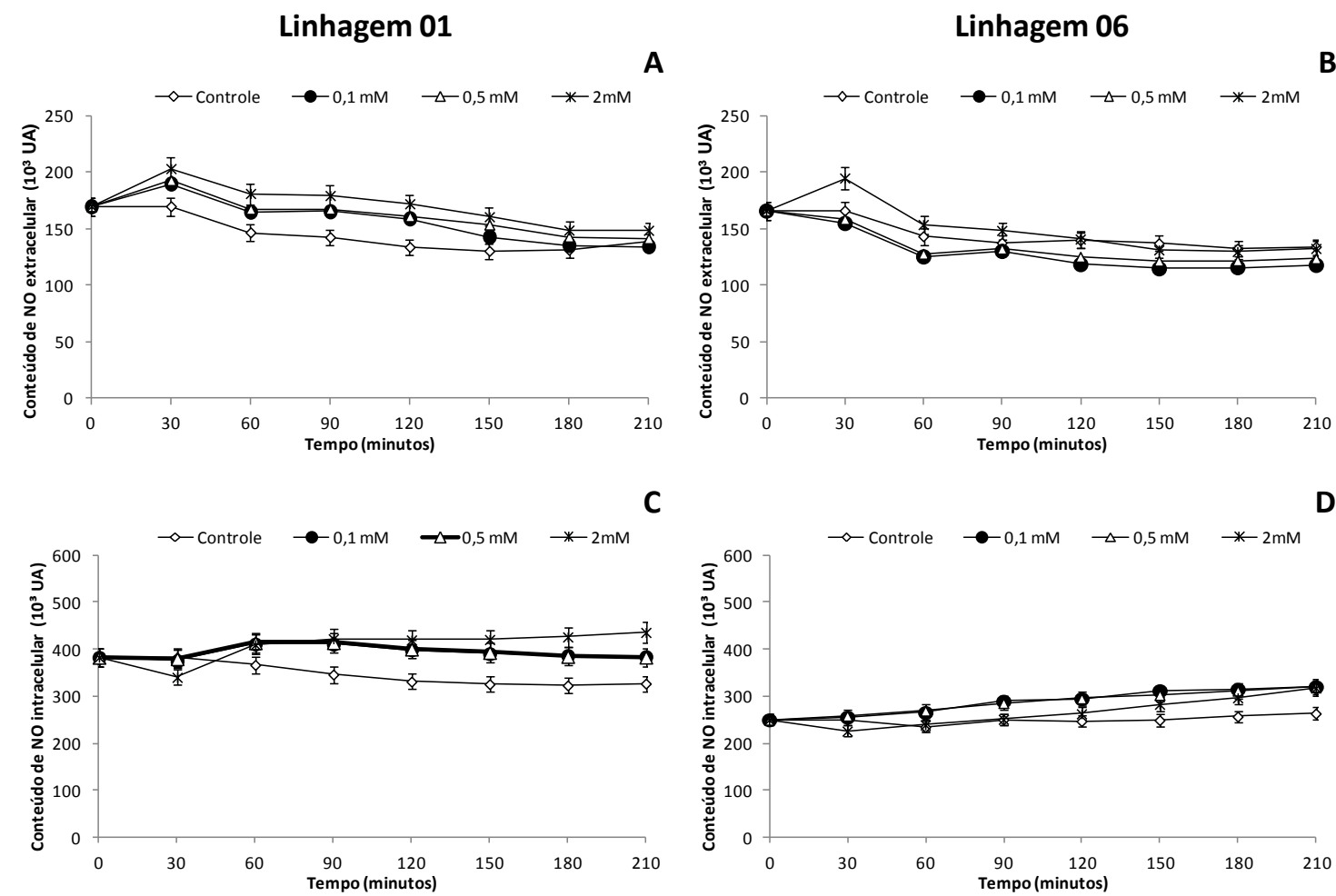

Figura 7. Conteúdo de NO extracelular ( $A$ e $B$ ) e intracelular (C e D) em suspensões celulares da linhagem 01 ( $A$ e $C$ ) e 06 ( $B$ e $D$ ) de A. angustifolia suplementada com diferentes concentrações de ácido salicílico. Média \pm desvio padrão, $n=3$. (UA= unidades de absorbância).

\subsubsection{Conteúdo de ERO}

O efeito da adição do AS na produção de ERO foi avaliado nas suspensões celulares das linhagens 01 e 06 (Figura 8).

\section{Observou-se que:}

a) a adição de ácido salicílico foi inibitória para a liberação de ERO na linhagem 01 (Figura 8A). Os maiores valores foram obtidos para o material controle, ocorrendo uma redução com o aumento na concentração de AS. A concentração de $2 \mathrm{mM}$ inibiu completamente a produção de ERO;

b) as curvas observadas nos vários tratamentos, com exceção de $2 \mathrm{mM}$, seguem um padrão sigmóide com uma fase linear até o período de 60 a 90 min.; 
c) o comportamento observado para a linhagem 06 apresentou resultados similares aos observados para a linhagem 01 (Figura 8 B);

d) a linhagem 01 possui produção de ERO superior à observada para a linhagem 06;

e) a produção de ERO da linhagem 06 apresentou menos inibição da produção de ERO em amostras incubadas com AS quando comparada à linhagem 01.
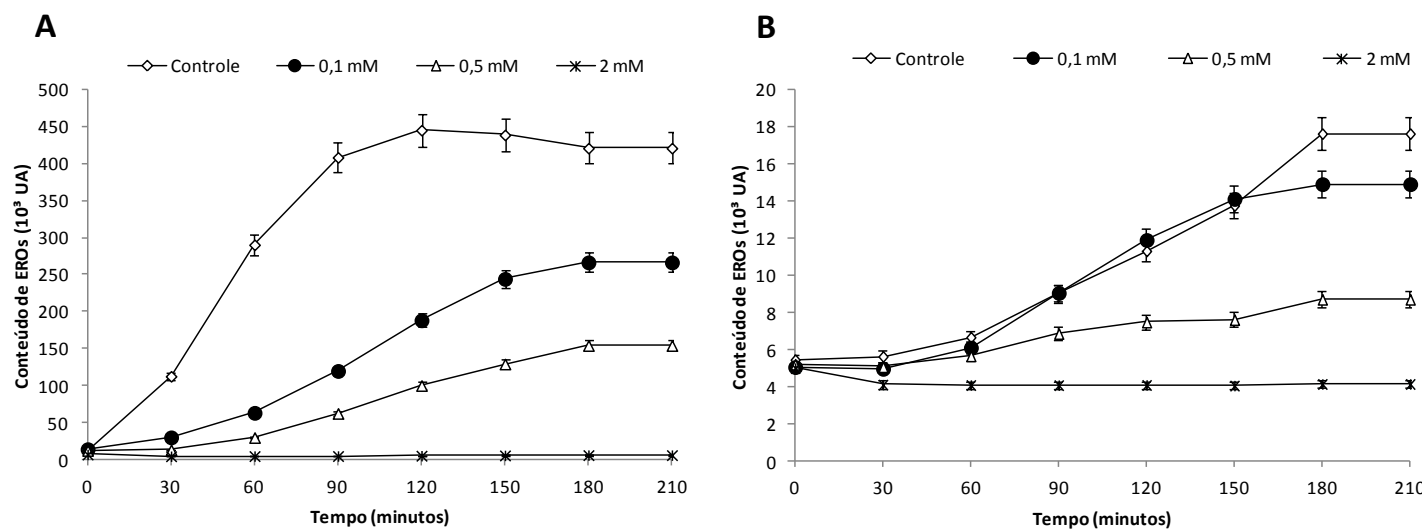

Figura 8. Conteúdo de ERO intracelular na suspensão celular da linhagem 01 (A) e 06 (B) de A. angustifolia suplementada com diferentes concentrações de AS $(0 ; 0,5$; e $2 \mathrm{mM})$. Média \pm desvio padrão, $n=3$. ( $U A=$ unidades de absorbância).

\subsubsection{Efeito da suplementação de doador (GSNO) e inibidor (PTIO) ao meio de cultura na produção de NO intra e extracelular}

A suplementação do meio de cultura com AS (0,5 e 2 mM) e GSNO (1 mM) aumentou a liberação de NO extracelular da linhagem 01 (Figura 9A).

Observou-se que:

a) todos os tratamentos promoveram aumento do conteúdo de NO quando comparados ao controle;

b) culturas incubadas em meio contendo AS e GSNO combinados apresentaram maiores liberações de NO extracelular quando comparados à ação isolada do GSNO;

c) a combinação de GSNO e 0,5 mM de AS demonstrou ser a mais efetiva para aumentar a produção de NO desta linhagem.

A análise da linhagem 06 demonstrou que o tratamento contendo somente GSNO foi o mais eficaz para aumentar a produção de NO (Figura 9B). 
Observou-se que:

a) a combinação do AS com GSNO alcançou níveis intermediários na produção de NO quando comparada ao tratamento com GSNO isolado e controle;

b) a combinação de GSNO com $0,5 \mathrm{mM}$ de AS foi mais efetiva na produção de NO seguida por $2 \mathrm{mM}$ de AS.

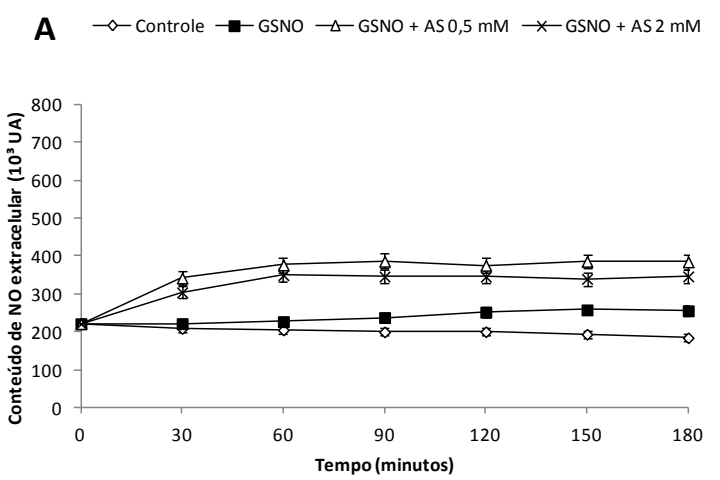

B $\leadsto$ Controle $\rightarrow-$ GSNO $\neg-$ GSNO + ASO,5 mM $\rightarrow$ GSNO + AS $2 \mathrm{mM}$

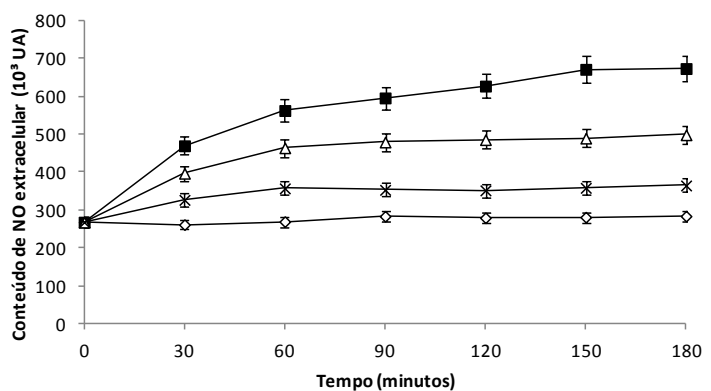

Figura 9. Conteúdo de NO extracelular nas suspensões celulares embriogênicas da linhagem 01 (A) e 06 (B), após 3h de incubação, nos tratamentos controle e suplementados com GSNO com diferentes concentrações de AS (0; 0,5 e 2mM). Média \pm desvio padrão, $n=3$. (UA= unidades de absorbância).

A incubação de culturas embriogênicas da linhagem 01 em meio acrescido de GSNO promoveu maior produção de NO intracelular em todos os tratamentos (Figura 10A).

Observou-se que:

a) a maior produção de NO intra foi medida entre 30 e 120 min. no tratamento contendo $2 \mathrm{mM}$ de AS e GSNO;

b) amostras incubadas na presença de GSNO demonstraram valores intermediários de NO quando comparadas aos tratamentos combinados ao AS (0,5 e $2 \mathrm{mM})$.

Foram observados conteúdos similares de NO intracelular entre todos os tratamentos até os 90 minutos nas avaliações realizadas com a linhagem 06 (Figura 10B).

Observou-se que:

a) a maior produção de NO foi observada para o tratamento contendo somente GSNO entre 120 e 180 min.; 
b) tratamentos contendo AS e GSNO mantiveram conteúdos similares entre si e intermediários quando comparados às amostras incubadas em GSNO e ao controle.
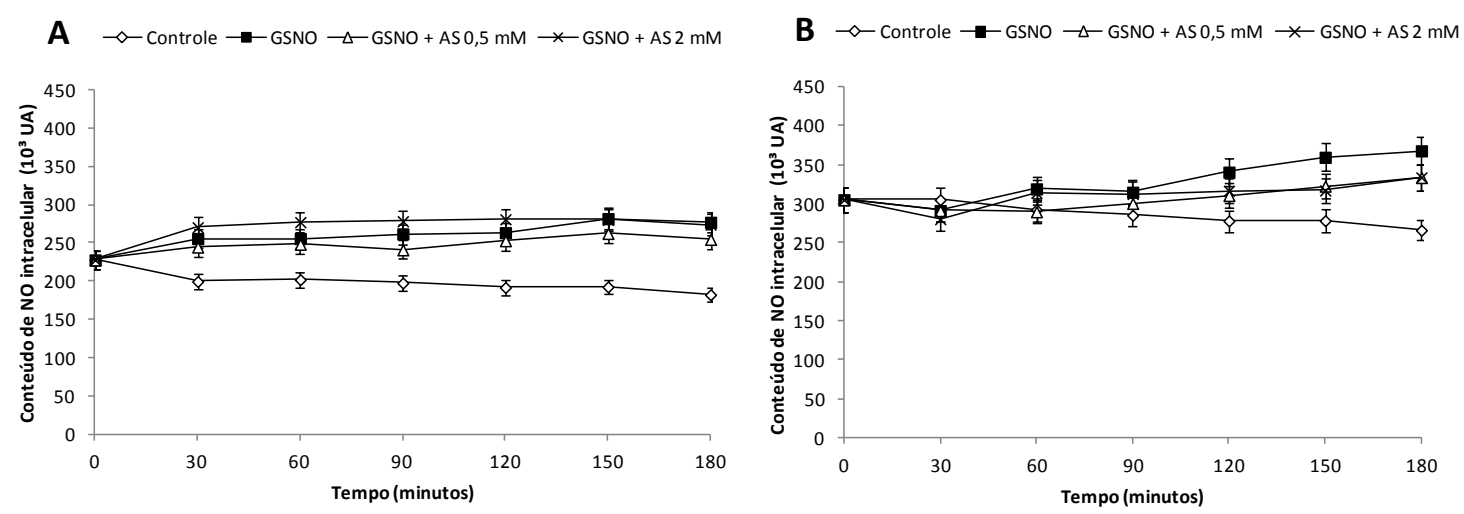

Figura 10. Conteúdo de NO intracelular nas suspensões celulares embriogênicas da linhagem 01 (A) e 06 (B), após 3h de incubação, nos tratamentos controle e suplementados com GSNO com diferentes concentrações de AS $(0 ; 0,5$ e $2 \mathrm{mM})$. Média \pm desvio padrão, $n=3$. (UA= unidades de absorbância).

A adição de PTIO promoveu a queda na liberação de NO extracelular em todos os tratamentos, independentemente da utilização de GSNO isolado ou combinado com AS, em ambas as linhagens do início ao fim da avaliação (Figura 11A e B).
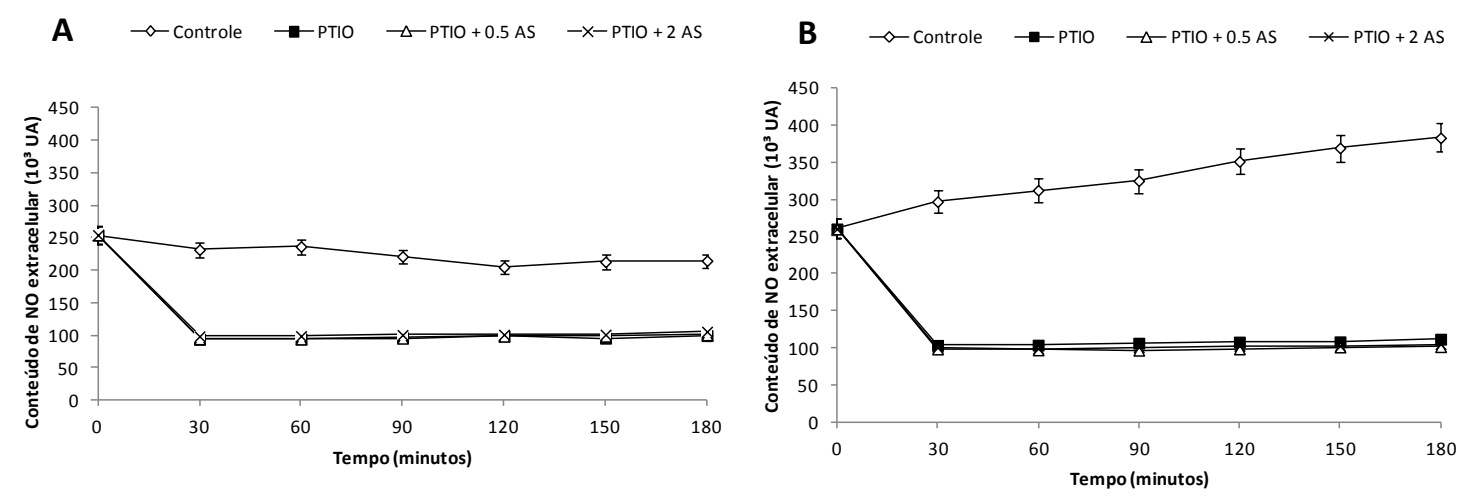

Figura 11. Conteúdo de NO extracelular nas suspensões celulares embriogênicas da linhagem 01 (A) e 06 (B), após 3h de incubação, nos tratamentos controle e suplementados com PTIO com diferentes concentrações de AS $(0 ; 0,5$ e $2 \mathrm{mM})$. Média \pm desvio padrão, $n=3$. (UA= unidades de absorbância).

Assim como observado na liberação de NO extracelular, verificou-se que a adição de PTIO promoveu queda na liberação de NO intracelular em todos os tratamentos, utilizando-se GSNO isolado ou combinado com AS, em ambas as linhagens por todo o período de avaliação (Figura 12A e B). 

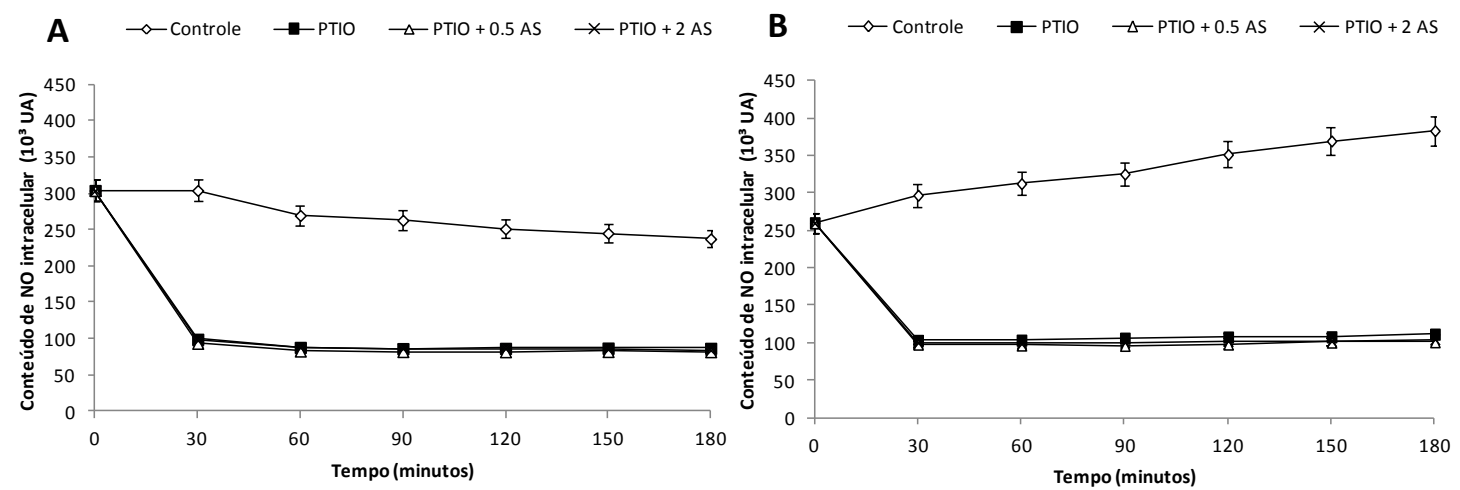

Figura 12. Conteúdo de NO intracelular nas suspensões celulares embriogênicas da linhagem 06, após 3h de incubação, nos tratamentos controle e suplementados com PTIO com diferentes concentrações de AS (0; 0,5 e 2mM). Média \pm desvio padrão, $n=3$. (UA= unidades de absorbância).

\subsubsection{Efeito da suplementação de doador (GSNO) e inibidor (PTIO) ao meio de cultura na produção de ERO}

Tratamentos com AS e/ou GSNO promoveram diminuição na concentração das ERO da linhagem 01 (Figura 13A).

Observou-se que:

a) células mantidas em meio suplementado com GSNO apresentaram menor redução de ERO;

b) a combinação de GSNO e AS promoveu diminuição acentuada nos níveis de ERO quando comparados ao controle.

Para a linhagem 06 (Figura 13A), observou-se que:

a) a quantidade de ERO no tratamento controle foi maior;

b) a combinação de $0,5 \mathrm{mM}$ de AS e GSNO proporcionou a menor queda na quantidade de ERO, seguido pelo tratamento contendo somente GSNO;

c) a menor produção de ERO foi observada em culturas incubadas com a combinação de GSNO e 2 mM de AS. 

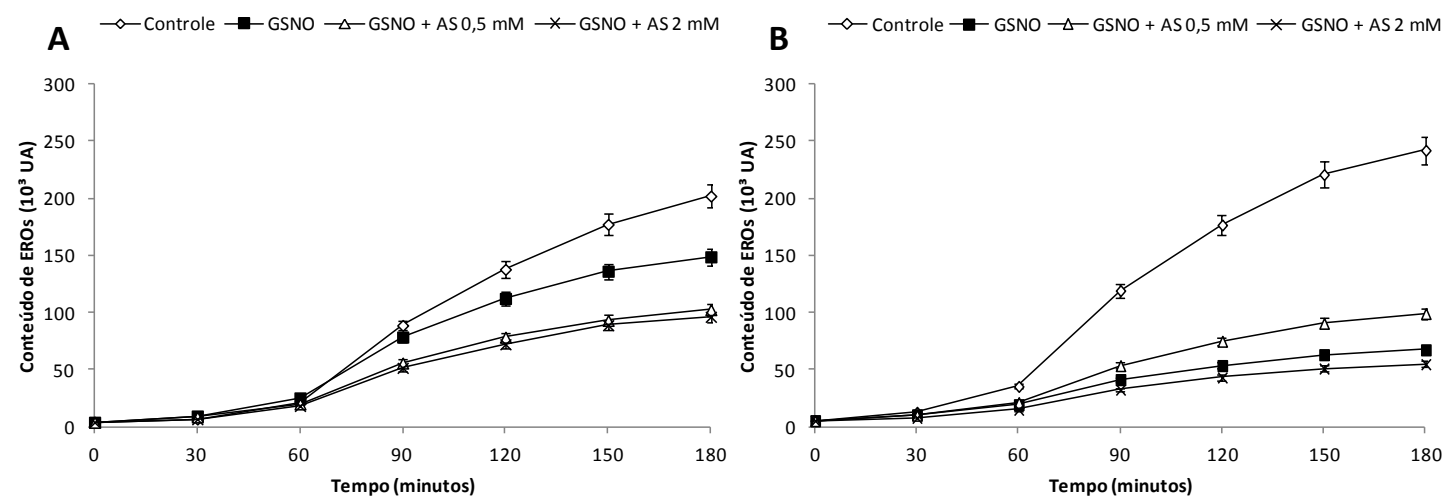

Figura 13. Conteúdo de ERO nas suspensões celulares embriogênicas da linhagem 01, após $3 \mathrm{~h}$ de incubação, nos tratamentos controle e suplementados com GSNO. Média \pm desvio padrão, $n=3$. (UA= unidades de absorbância)

A adição de PTIO promoveu queda na produção de ERO das duas linhagens em todos os tratamentos (Figura 14A e B).
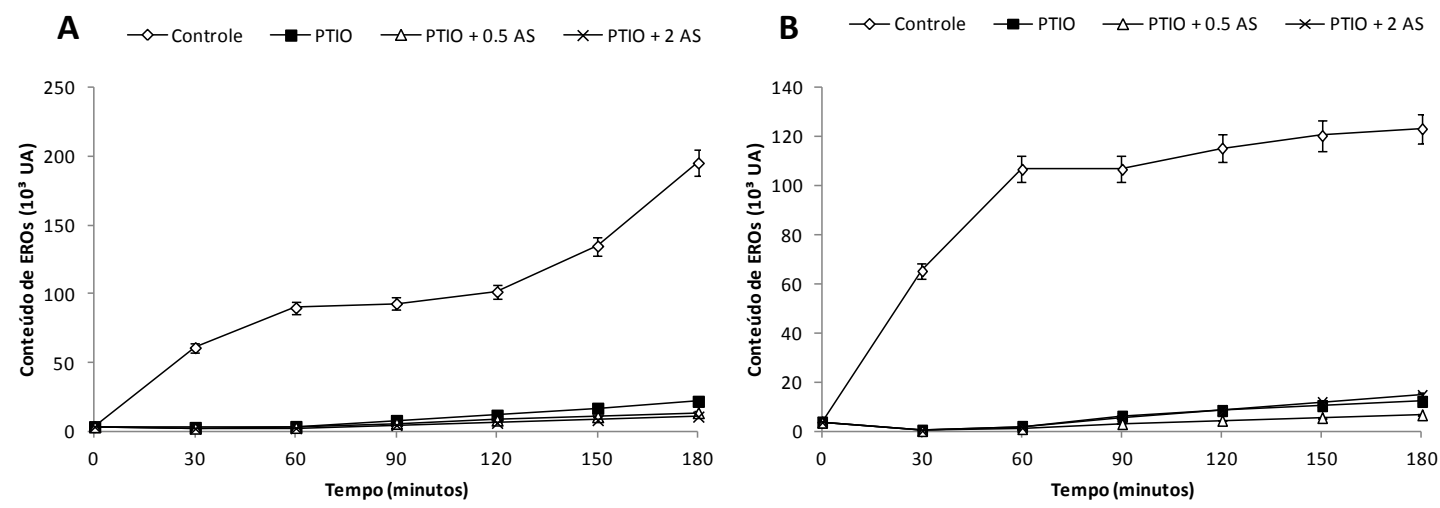

Figura 14. Conteúdo de ERO nas suspensões celulares embriogênicas da linhagem 06, após $3 \mathrm{~h}$ de incubação, nos tratamentos controle e suplementados com PTIO (B). Média \pm desvio padrão, $n=3$. (UA= unidades de absorbância).

\subsection{Análises moleculares}

4.4.1. Avaliação da expressão do gene SERK em linhagens celulares com diferentes potencias embriogênicos proliferadas na presença do AS

Para avaliar o efeito da suplementação de AS na expressão de AaSERK, as linhagens 01 (responsiva) e 06 (não responsiva) foram submetidas a análise de qPCR. Não foram observadas diferenças significativas $(p \leq 0,05)$ entre os genótipos (Figura 
15). A partir destes resultados foi realizado um experimento utilizando apenas a linhagem 01 onde as culturas foram incubadas em meio suplementado com 0,1 mM de AS (Item 4.2.2.2) por 1, 4, 16, 32 e 64 horas e a expressão de AaSERK foi novamente avaliada por qPCR.

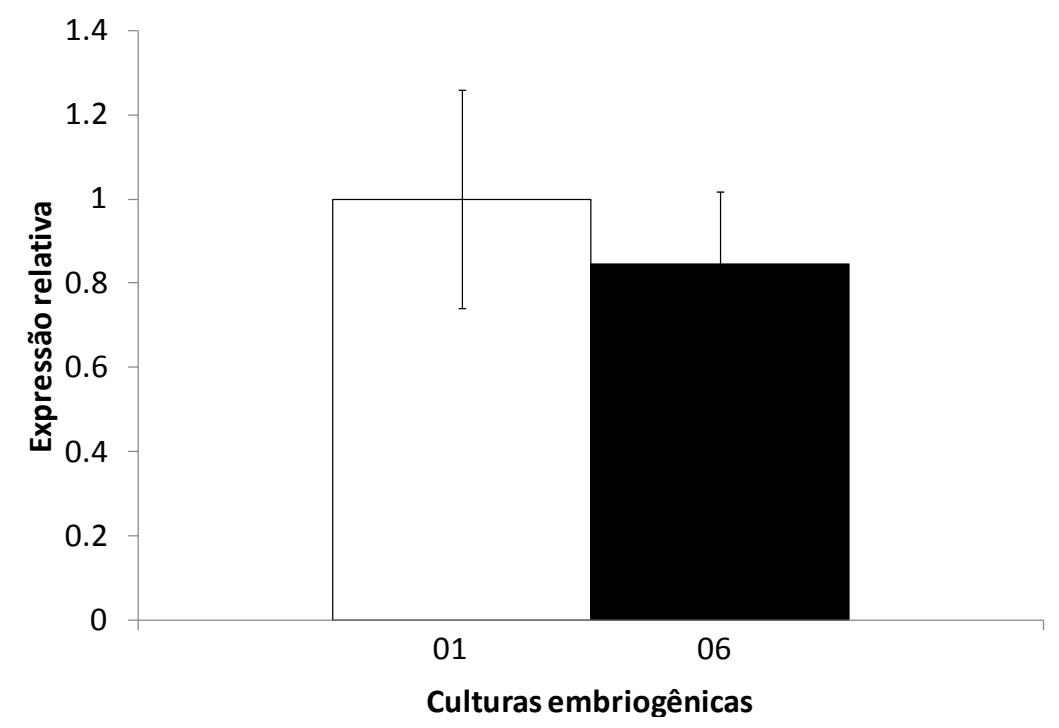

Figura 15. Expressão relativa do gene SERK em culturas com diferentes potenciais embriogênicos. Dados obtidos por meio do FgStatistics.

\subsubsection{Expressão da SERK por qPCR em linhagens celulares proliferadas na presença do AS.}

Os níveis de expressão ao longo do período de incubação de 1 a 16 horas (Figura 16) dobraram em relação ao controle de cada tratamento. É interessante ressaltar que após este período há um decréscimo signifcativo $(p \leq 0,05)$ na expressão de AaSERK (Figura 16). 


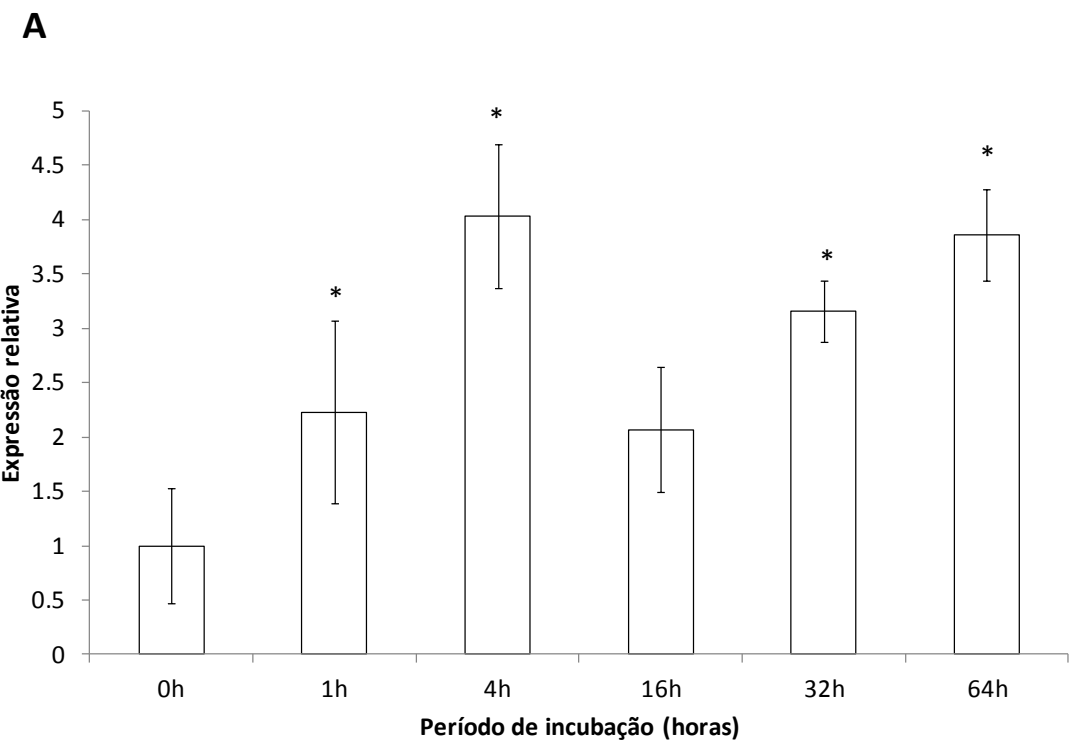

B

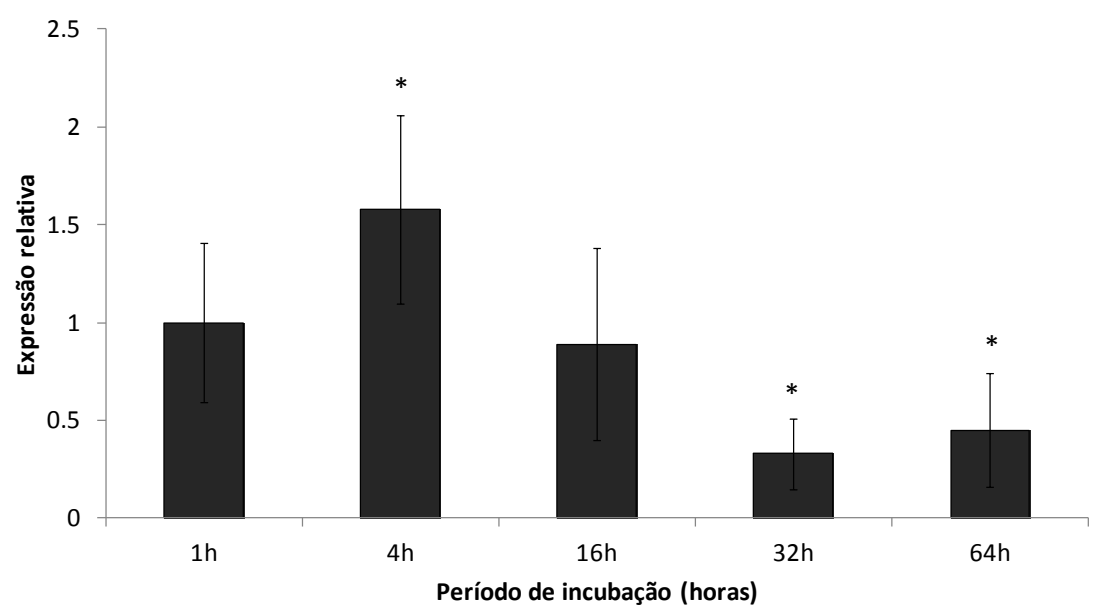

Figura 16. Expressão relativa do gene SERK na linhagem responsiva aos agentes de maturação (01) ao longo de diferentes períodos em cultura na ausência $(A)$ e presença de ácido salicílico $0,1 \mathrm{mM}$ (B). Média \pm desvio padrão, $n=3$. $\left({ }^{*}\right)$ Diferenças estatísticas entre os grupos $(P<0,05)$. Dados obtidos pelo FgStatistics.

Na comparação entre todas as amostras (Figura 17), observou-se que:

a) os níveis de expressão do gene SERK nos controles com períodos de incubação de 4, 32 e 64 h são elevados;

b) amostras incubadas em $0,1 \mathrm{mM}$ de AS apresentaram maior expressão nos períodos de 1, 4, e 16h. 


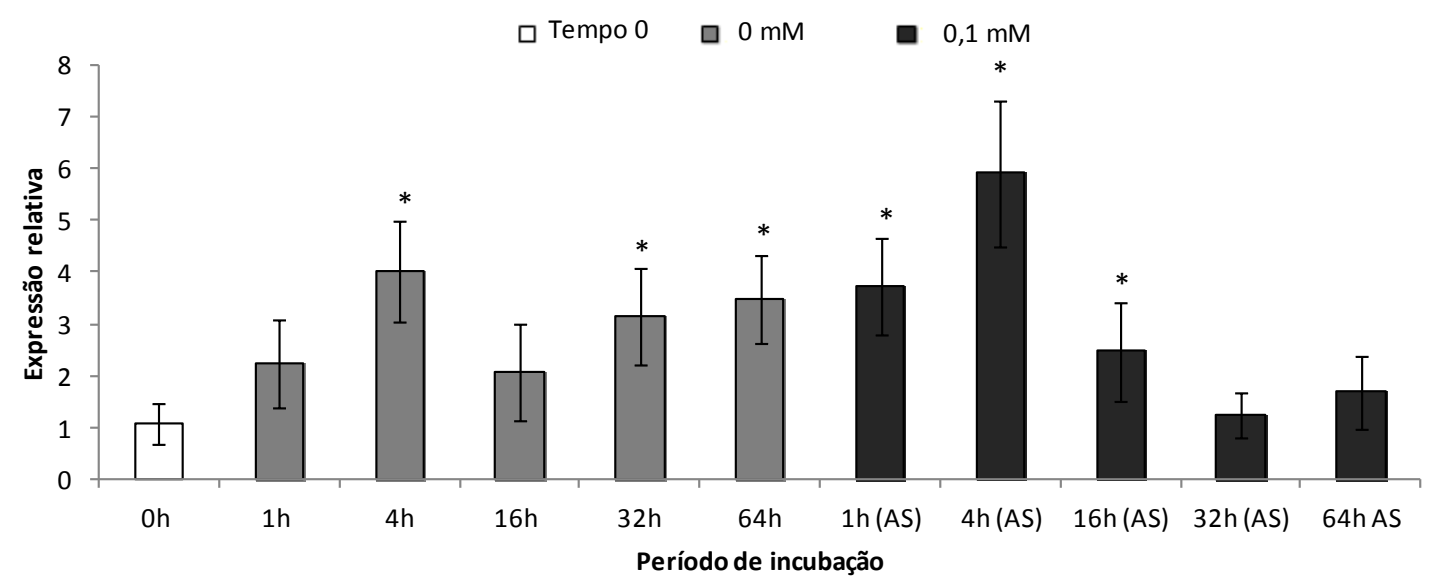

Figura 17. Expressão relativa do gene SERK na linhagem responsiva aos agentes de maturação (01) ao longo de diferentes períodos em cultura na ausência e presença de ácido salicílico $0,1 \mathrm{mM}$. Média \pm desvio padrão, $n=3$. $\left(^{*}\right)$ Diferenças estatísticas entre os grupos $(P<$ 0,05). Dados obtidos pelo FgStatistics. 


\section{DISCUSSÂO}

\subsection{Conteúdo de AS e SAG em embriões zigóticos}

O ácido salicílico pertence a um grupo de fenóis vegetais amplamente distribuídos em plantas possuindo um papel importante na regulação do desenvolvimento e crescimento vegetal (Raskin, 1992). O AS pode ser sintetizado por duas vias: a primeira a partir do cinamato, pela fenilalanina amonia liase (PAL), e a segunda pela via metabólica do isocorismato, por ação da isocorismato sintase (ICS) (Chen et al., 2009). A produção de AS pela via da PAL corresponde a $5 \%$ e é efetuada no citosol (Huang et al., 2010), 95\% é sintetizado pela via da ICS nos cloroplastos (Chen et al., 2009). Os organismos vegetais empregam o AS nas respostas a diversos estresses abióticos como: hídrico, de temperatura, toxicidade e osmótico (Vicente \& Plasencia, 2011; Miura, 2014) e na regulação de processos de desenvolvimento como germinação, (Rajjou et al., 2006; Lee et al., 2011), crescimento (Scott et al., 2004), senescência (Vogelmann et al., 2012) e fechamento dos estômatos (Khokon et al., 2011; Kalachova et al., 2013). O acúmulo de AS resulta de sua produção e remoção através da degradação ou formação de seus derivados (Davies, 1995), sendo seu conjugado predominante em plantas o AS-2-O- $\beta$-D-glucoside (Hayat \& Ahmad, 2007). A produção de SAG é catalizada pela UDP-glucose:SA glucosyltransferase ( $\beta$-GTase), cuja atividade é estimulada quando os níveis de AS aumenta nos tecidos (Davies, 1995). Os níveis de AS variam entre espécies, de 0.05 a $5.0 \mu \mathrm{g}$ por grama de tecido, entretanto algumas espécies como o arroz, podem acumular mais de $30 \mu \mathrm{g}$ (Davies, 1995).

No presente trabalho, a variação dos conteúdos de AS e SAG observados durante o desenvolvimento do embrião de $A$. angustifolia apresentou maior acúmulo no estádio de embriogênese inicial (Tabela 2). A elevação no conteúdo de AS aumenta significativamente a atividade de enzimas antioxidantes e a presença de compostos não enzimáticos resultando no aumento da tolerância ao estresse (Ashraf et al., 2010; Hayat et al., 2010). Enzimas antioxidantes possuem um papel importante no crescimento e desenvolvimento vegetal protegendo as sementes de estresses abióticos através da remoção de ERO (Nagamiya et al., 2007). A predominância do AS, na fase de embriogênese inicial, pode sugerir uma atuação deste composto mais relacionada à defesa da estrutura embrionária num estádio onde a taxa de divisão celular é alta e os meristemas são estabelecidos. Estes resultados corroboram os obtidos por Balbuena et al. (2009), onde demonstrou-se que, durante a fase inicial de desenvolvimento do embrião zigótico de $A$. angustifolia, as proteínas mais expressas 
são aquelas relacionadas ao metabolismo do estresse oxidativo em contraste com as fases tardias da embriogênese.

Além de atuar na redução de prolina e níveis de peroxidação lipídica (Asadi et al., 2013), o AS também interage com o acúmulo de hormônios como auxinas e citocininas no sistema Zea mays (Bagheri, 2014). Os conteúdos de AS observados na embriogênese de $A$. angustifolia, podem estar relacionados com o papel protetor dos fenóis sobre auxinas, uma vez que o AS previne a oxidação do ácido-indol-acético (AIA) (Schneider \& Whitman, 1974). Em vegetais, os conteúdos livres de AS e AIA são mantidos em baixos níveis, sendo encontrados em sua maior parte na forma conjugada (Sticher et al., 1997; Ljung et al., 2002). Uma das formas conjugadas de AS é o saliciloil-aspartato (AS- Asp), o único conjugado AS-amido identificado em plantas como Vitis vinifera (Steffan et al., 1988), Phaseolus vulgaris (Bourne et al.,1991) e Arabidopsis (Zhang et al., 2007). Assim como o AS, o AIA pode ser conjugado com aspartato (AIA- Asp), sendo permanentemente desativado por degradação oxidativa e ocasionando a liberação do aspartato (Zhang et al., 2007). Astarita et al. (2003) identificaram maior concentração de aspartato nos estádios tardios da embriogênese de $A$. angustifolia, enquanto Steiner et al. (2008) identificaram um maior conteúdo de AIA nas fases iniciais, decrescendo nas etapas posteriores. Sugere-se que menores conteúdos de AS observados nas fases de embriogênese tardia e matura podem ser associados aos menores conteúdos de AIA, gerando por sua vez um aumento nos níveis de aspartato. O aspartato, além de estar envolvido na translocação de nitrogênio, é precursor da síntese de asparagina, treonina, metionina, lisina e isoleucina (Lam et al., 1995). A asparagina funciona como transportador e estoque de nitrogênio nas plantas (Azevedo et al., 2006).

\subsection{Efeito do AS na indução da embriogênese somática}

A embriogênese somática é um processo complexo, onde o sucesso de cada etapa depende do desempenho adequado na etapa anterior (Zimmerman, 1993). A indução e o controle da embriogênese somática são dependentes da fonte de explante, do genótipo da planta matriz e do tipo e concentração dos reguladores de crescimento adicionados ao meio de cultura (Guerra et al., 1999).

Diferentes estudos apontam a importância do AS na indução e desenvolvimento de embriões somáticos (Yeh \& Chang, 1987; Hutchinson, 1996; Pius, 1993). Em Coffea arabica, a utilização de concentrações picomolares de AS em culturas celulares embriogênicas resultou no aumento do crescimento celular e da 
sincronização do desenvolvimento de embriões somáticos (Quiroz-Figueroa et al., 2001). Luo et al. (2001) relatam que, em Astragalus adsurgens, a adição de AS no meio de maturação aumentou significativamente o número de embriões somáticos e a sincronização de seu desenvolvimento.

No presente trabalho, a suplementação do meio de cultura com 0,1 e 0,5 mM de AS não induziu a formação de calos e/ou embriões somáticos, além de promover a oxidação dos explantes. Concentrações de 1 e 2 mM de AS, embora tenham preservado as estruturas embrionárias, não possibilitaram a verificação de alterações na morfologia ou coloração das mesmas após os 45 dias de cultivo (Figura 5). De acordo com Quiroz-Figueroa et al. (2006), uma explicação para este comportamento seria um efeito duplo do AS, onde, em baixas concentrações a programação de células somáticas seria induzida para um estado totipotente, enquanto em altas concentrações esta programação pode ser inibida a fim de preservar a viabilidade celular.

Mulgund et al. (2012) obtiveram resultados similares aos observados para $A$. angustifolia no sistema Pinus roxburghii ao utilizar AS sem outros reguladores de crescimento. A suplementação do meio com AS em baixas concentrações $(0,1$ a 0,4 $\mathrm{mg}^{-1}$ ) não aumentou efetivamente a porcentagem de embriões somáticos, enquanto altas concentrações (2-5 mg-1) promoveram o escurecimento dos explantes e calos, não ocorrendo proliferação ou formação de culturas embriogênicas. Contudo, o AS combinado a auxinas e citocininas no meio de indução, promoveu aumento da embriogênese somática. Além disso, Lichtenthaler (1998), propôs que a resposta fisiológica a condições estressantes pode depender do estado das células e do nível (tempo e intensidade) em que são mantidas nestas condições. Quando o nível de estresse excede a tolerância celular as células morrem, mas se os níveis de estresse forem baixos, as células podem induzir mecanismos de adaptação.

\subsection{Efeito do AS em meio líquido e semi-sólido na fase de proliferação das culturas embriogênicas}

A suplementação do meio de cultura com AS tem sido relacionada com respostas de inibição do crescimento vegetal, termotolerância, tolerância ao resfriamento e salinidade (Lopez-Delgado et al., 2007). Em suspensões celulares de Ginko biloba, o AS tem sido utilizado como elicitor visando aumento da produção de metabólitos secundários (bilobalides e ginkgolides) no meio de cultura (Kang et al., 2006). Um incremento da embriogênese somática após a suplementação do meio de 
cultura com AS foi observado em espécies como Daucus carota (Durner \& Klessig, 1995), Pennisetum americanum (Larque-Saavedra,1979), Pelargonium $\times$ hortorum Bailey (Leslie \& Ramani, 1988), Astragalus adsurgens (Luo et al., 2001) e Pinus roxburghii (Mulgund et al., 2012). Além da atuação do AS na embriogênese somática, diversos estudos têm relacionado sua ação no florescimento, aumento de divisão celular e crescimento in vitro em Coffea arabica (Hutchinson \& Saxena, 1996), fechamento de estômatos em Phaseolus vulgaris (Cleland \& Ajami, 1974) e aumento do acúmulo de nitrato em raízes de Pinus patula (Cleland et al., 1982).

No presente trabalho, o aumento de matéria fresca observado apenas no tratamento controle e 0,1 mM (Tabela 5) está de acordo com o observado em espécies como Hordeum vulgare, onde Pancheva et al. (1996) observaram um crescimento significativamente maior, em plântulas suplementadas com baixas concentrações de AS. Em Zea mays e Glycine max L. a aplicação de AS acelerou a produção de massa seca (Khan et al., 2003). Fariduddin et al. (2003) também observaram um aumento máximo no acúmulo de matéria seca em plântulas de Brassica juncea após a suplementação com concentrações inferiores a 10-3 M de AS, enquanto concentrações de $10^{-3}$ e 10-2M demonstraram ser inibitórias por promoverem mudanças permanentes na organização da membrana das células, causando injúrias no metabolismo e crescimento. $O$ efeito inibitório das demais concentrações (0,5- 2mM) de AS foi observado em CEs de A. angustifolia. Este comportamento sugere uma inibição promovida pelo AS quando as concentrações são iguais ou superiores a $0,5 \mathrm{mM}$. Os resultados obtidos pelo presente trabalho corroboram os dados obtidos com mutantes de $A$. thaliana, os quais acumulam altas concentrações de AS, resultando em atrofia e nanismo (Kachroo et al., 2000; Shirano et al., 2002; Sasek et al., 2014).

As quantificações de AS endógeno das CEs demonstram conteúdos de AS superiores na linhagem 01 quando comparadas à linhagem 06. Elbl et al. (2014), ao analisarem o transcriptoma de culturas embriogênicas das linhagens 01 e 06 observaram padrões distintos de acúmulo de transcritos, como por exemplo, fatores de transcrição NAC, WRKY, ERF, MYB, HD-ZIP e famílias bZIP, associados à embriogênese e resposta a estresse induzido por condições de cultivo in vitro (Xu et al., 2012; Jin et al., 2013), sugerindo seu envolvimento no potencial embriogênico destas linhagens de $A$. angustifolia. No presente estudo, a linhagem 01 , não bloqueada para desenvolvimento de embriões, apresentou maior conteúdo de AS endógeno quando comparada à linhagem 06. A linhagem 01 apresenta maior 
expressão dos genes relacionados à defesa (Elbl et al., 2014), fato que pode indicar uma maior capacidade adaptativa desta linhagem na tolerância a estresse. Sugere-se que os maiores conteúdos de AS endógeno podem auxiliar na maior adaptação observada para a linhagem 01 .

\subsection{Efeito do AS, GSNO e PTIO na produção de NO e ERO em suspensões celulares embriogênicas}

Em coníferas, alterações no meio de cultura relatadas como estressantes para as células, são necessárias para uma reprogramação da via morfogenética. (Silveira et al., 2004; Stasolla \& Yeung, 2003). O AS, o NO e as ERO são moléculas envolvidas na resposta ao estresse e influenciam o balanço redox celular (Durrant \& Dong 2004; He et al., 2007).

O NO é um radical livre gasoso, com baixo peso molecular (Corpas et al., 2006), sua sinalização inclui diversos processos fisiológicos como diferenciação celular, morte celular programada, embriogênese, germinação, crescimento de raiz e resposta a estresse (Silveira et al., 2006; Osti et al., 2010; Beligni et al., 2002; SantaCatarina, et al., 2007). O NO é sintetizado, principalmente em tecidos com crescimento ativo, como o eixo embrionário e cotilédones, com níveis menores nos tecidos maduros e órgãos senescentes (Leshem et al., 1996; Caro \& Puntarulo, 1999). Além disso, o NO pode induzir o acúmulo de AS (Delledonne, 2005) e atuar como antioxidante em plantas, minimizando os danos causados pelas ERO (Bai et al., 2011), dependendo da concentração, tecido e tipos de estresse (Beligni \& Lamattina, 1999; Hsu \& Kao, 2004).

A explosão oxidativa (oxidative burst), é uma resposta da célula perante algum fator estressante, pode ser descrita como um desequilíbrio entre a formação e remoção de ERO e/ou pela redução nas defesas antioxidantes (Mahalingam \& Fedoroff, 2003) Esse evento atua em diferentes processos, como na indução dos níveis de auxina endógenos (Pasternak et al., 2002; Correa-Aragunde et al., 2006). Os resultados obtidos no presente trabalho para a quantificação de ERO (Figura 8), diferem daqueles observados para outros sistemas vegetais como Arabidopsis (Sasek et al., 2014) e Astragalus adsurgens (Luo et al., 2001), onde foi verificado um aumento de ERO nos tratamentos suplementados com AS. Em A. angustifolia, mesmo a menor concentração $(0,1 \mathrm{mM})$ promoveu a diminuição das ERO. Luo et al.(2001), observou que a suplementação do meio com $150 \mu \mathrm{M}$ de AS promoveu um aumento significativo na produção de peróxido de hidrogênio $\left(\mathrm{H}_{2} \mathrm{O}_{2}\right)$, sugerindo que 0 aumento na 
porcentagem da ocorrência da embriogênese somática estava ligado a essa maior produção de $\mathrm{H}_{2} \mathrm{O}_{2}$. Além disso, este aumento de $\mathrm{H}_{2} \mathrm{O}_{2}$ ocorreu especificamente no estádio da ES correspondente ao globular da EZ. Outros estudos propõem que o aumento da ocorrência da ES está relacionado ao aumento de $\mathrm{H}_{2} \mathrm{O}_{2}$ (Lamb \& Dixon, 1997; Berglund \& Ohlsson, 1995). Possivelmente diferenças de respostas estejam relacionadas com a concentração do AS incorporado ao meio de cultura. Sugere-se que o meio de cultura para o sistema $A$. angustifolia seja suplementado com concentrações limite de $0,1 \mathrm{mM}$ de $A S$, uma vez que essa concentração não inibiu expressivamente a quantidade de ERO intracelular. Com base nos resultados da quantificação de NO e ERO, sugere-se que o AS promoveu a redução das ERO. Considerando-se que o NO reage diretamente com as ERO para formar as espécies reativas de nitrogênio (ERN) (Grun et al., 2006; Moreau et al., 2010) e auxilia no equilíbrio redox da célula, a menor disponibilidade das ERO pode ter ocasionado o aumento da quantidade de NO devido à não formação de ERN (Moreau et al., 2010). Uma forma de avaliar se o AS reage diretamente com as ERO causando este desequilíbrio no estado redox seria pela suplementação do meio de cultura com AS e posterior quantificação das ERN com sondas específicas como a 2, 7Dichlorodihydrofluorescein (DCDHF).

O composto S-nitrosoglutathiona (GSNO), produto da reação do $\mathrm{NO} \mathrm{com}$ a GSH (Erdei \& Kolbert, 2008), atua como uma molécula intermediária estável e subsequentemente doadora de $\mathrm{NO}$ ao ser transportada para tecidos com baixas concentrações de $\mathrm{O}_{2}$, para liberação do NO (Durzan \& Pedroso, 2002). Com relação ao efeito da suplementação do meio de cultura com GSNO sobre o aumento de NO externo (Figura 9) e interno (Figura 11), sugere-se que pode ter sido causado devido à doação de NO pelo GSNO. Esta situação pode ocorrer em tecidos embrionários nos estádios iniciais de desenvolvimento, onde $\mathrm{O}_{2}$ disponível é principalmente convertido para superóxido (Rolletschek et al., 2004), consequentemente estes tecidos apresentam baixa disponibilidade de $\mathrm{O}_{2}$ e a liberação do NO é favorecida.

O ambiente redox também pode ser definido pelo estado de moléculas específicas como a glutationa reduzida (GSH) e a glutationa dissulfeto (GSSG), capaz de se converter em forma reduzida ou oxidada de acordo com a produção de ERO, auxiliando no controle redox (Stasolla, 2010). Considerando-se uma menor disponibilidade de $\mathrm{O}_{2}$ como receptor de elétrons, e que o GSNO, ou GSNO com AS, estimularam a liberação de NO, sugere-se a ocorrência de um aumento na quantidade de GSHs que possivelmente interagiram com as ERO (Figura 13). Esta situação 
reduziria a presença das ERO no ambiente celular, acarretando o desequilíbrio do sistema. A razão GSH/GSSG e sua manipulação aumentaram a taxa de embriogênese somática em Brassica napus (Belmonte et al., 2006), sendo o estado redox celular um fator relevante que interfere no processo de embriogênese somática (Belmonte et al., 2005).

A incorporação de PTIO, um sequestrador de $\mathrm{NO}$, ao meio de cultura das suspensões celulares ocasionou não só a redução na produção de NO externo (Figura 10 e 12) como também acarretou a inibição da produção de ERO. Esta inibição das ERO foi inesperada, uma vez que a menor disponibilidade de NO promoveria uma diminuição de ERN, aumentando a disponibilidade das ERO. Kováčik et al. (2009) observaram que a suplementação do meio com PTIO diminuiu não só a concentração de NO, mas também reduziu a atividade da PAL e o acúmulo de fenóis solúveis. Ainda neste estudo, foi demonstrado que ao utilizar sequestradores de ERO junto ao PTIO os conteúdos de NO aumentaram significativamente, sugerindo que os efeitos do PTIO podem ser inespecíficos.

A inibição total da produção de NO não é um efeito desejável, como observado por Silveira et al. (2006), as PAs Spd e Spm possibilitam a evolução morfogenética das culturas embriogênicas de $A$. angustifolia mediante uma redução nos níveis endógenos de NO, sugerindo que a redução deste composto é essencial para a evolução destas culturas. Desta forma, sugere-se que em estudos futuros, sejam utilizados sequestradores específicos de NO em concentrações que não inibam totalmente sua produção.

\subsection{Expressão de SERK em culturas embriogênicas de Araucaria angustifolia}

A transição das células somáticas para o estado embrionário envolve um processo complexo que inclui a desdiferenciação, reativação celular, divisão e reprogramação do metabolismo e desenvolvimento (Fehér et al., 2003). Durante a embriogênese somática ocorrem mudanças, bioquímicas e morfológicas, através do desenvolvimento e relacionadas a alterações na expressão gênica, de tecidos induzidos. Muitos genes são diferencialmente expressos durante a embriogênese somática (Santos \& Aragão, 2009).

Entre os genes envolvidos, a ativação do SOMATIC EMBRYOGENESIS RECEPTOR KINASE 1 (SERK1) é requerida para a obtenção de totipotência celular (Elhiti et al., 2013). No presente trabalho, foi possível observar que, durante a etapa de proliferação, culturas da linhagem 01 (responsiva) apresentaram expressão relativa do 
gene AaSERK1 superior à observada para a linhagem 06 (não-responsiva) (Figura 15). A diferença observada na expressão relativa do gene AaSERK1 sugere diferentes capacidades destas linhagens em evoluir no processo de desenvolvimento do ES.

O gene SERK possui papel importante no processo de embriogênese somática e pertence à família de quinases, do tipo receptoras, com um domínio extracelular, rico em repetições de leucina (LRR-RLKs) (Schmidt et al., 1997). A maior expressão de AaSERK observada pelo presente trabalho, em culturas suplementadas com AS, pode ter sido desencadeada devido ao provável papel das LRR-RLKs em plantas na tradução de sinais do ambiente e informações das células vizinhas, iniciando respostas específicas durante o processo de desenvolvimento (Sasaki et al., 2007). Estas proteínas podem agir como receptores de sinais, sendo cruciais para o início da embriogênese somática.

A percepção dos estímulos externos durante as etapas da embriogênese somática é considerada crítica para a correta evolução do embrião somático (Yang \& Zhang, 2010). Além disso, Somleva et al. (2000), observaram um aumento nos níveis de transcritos de DcSERK1 em embriões somáticos de D. glomerata, que completaram a transição das culturas embriogênicas para embriões somáticos. Em $C$. nucifera, um pico da expressão do gene CnSERK1 foi observado em culturas embriogênicas aptas à formação de embriões somáticos (Perez- Nunez et al., 2009). Hecht et al. (2001) observaram que o SERK1 em Arabidopsis foi muito expresso durante a formação de células embriogênicas e durante a embriogênese inicial, sugerindo que a alta expressão de SERK1 confere competência embriogênica para a cultura. Hu et al. (2005) demonstraram que o gene SERK1 em O. sativa pode ser ativado por compostos sinalizadores de defesa, sugerindo sua mediação na transdução de resposta do sinal defensivo tanto quanto a indução da embriogênese somática. Verificou-se que, a expressão do gene SERK1 ocorre apenas na região das células embrionárias, não sendo identificadas no suspensor (Savona et al., 2012; Somleva et al., 2000). Steiner et al. (2012), observaram que, em CEs de $A$. angustifolia, a expressão da AaSERK1 ficou restrita às regiões periféricas dos calos, local este onde a maior parte das células embrionárias estão localizadas.

De acordo com o presente trabalho, as CEs mantidas por $4 \mathrm{~h}$ em meio suplementado com AS apresentaram o maior pico de expressão (Figura 16 B). Huang et al., (2007) observaram um pico na expressão de SERK1 entre 8 e $12 \mathrm{~h}$ de tratamento com AS em culturas embriogênicas de Musa acuminata, enquanto Luo et al. (2001) relata um aumento na taxa de formação de embriões somáticos em culturas 
de Astragalus adsurgens cultivadas em meio suplementado com $150 \mu \mathrm{M}$ de AS. Sugere-se que a incubação de CEs em baixa concentração de AS, $100 \mu \mathrm{M}$ no caso de A. angustifolia, pode apresentar uma sinalização adequada nestas estruturas caso este tempo de exposição não seja longo, visto que a exposição prolongada das CEs ao AS apresentou uma regulação negativa de AaSERK1 após quatro horas de incubação, atingindo níveis de expressão mais baixos que os controles entre 32 e $64 \mathrm{~h}$ (Figura 17) . Desta forma, ressalta-se a importância do estabelecimento de períodos limitados para exposição de culturas embriogênicas à sinalização do $A S$, não excedendo a tolerância celular ao estresse, e induzindo mecanismos de adaptação (Lichtenthaler, 1998). 


\section{CONCLUSÕES E PERSPECTIVAS FUTURAS}

A análise das etapas do desenvolvimento embrionário em sementes, além de permitir um melhor entendimento das bases moleculares e fisiológicas envolvidas no processo embriogênico, pode gerar informações importantes para a manipulação e otimização da técnica de multiplicação in vitro por embriogênese somática. O presente estudo fornece informações a respeito da sinalização envolvida durante o processo de desenvolvimento de sementes recalcitrantes e culturas embriogênicas.

Em estudos in vitro, os efeitos da suplementação de AS são dependentes de diferentes fatores como: espécie utilizada, condição fisiológica e tipo de explante utilizado. De acordo com os resultados obtidos, o sistema $A$. angustifolia, concentrações de 0,5 a 2 mM de AS promovem inibição do crescimento e da evolução das culturas embriogênicas. Culturas embriogênicas cultivadas em meio suplementado com AS (0- $2 \mathrm{mM})$, demonstram um aumento do conteúdo de AS endógeno. A suplementação com AS em meio de suspensões celulares, apresentou uma diminuição na quantidade de ERO. Sugere-se que a inibição de proliferação e diferenciação observada nas culturas embriogênicas podem ser relacionadas à intensa diminuição das ERO causada pela presença do AS. A suplementação do meio de cultura com AS seguida de uma análise do comportamento de enzimas antioxidantes como catalase, superóxido dismutase e peroxidases, auxiliariam a determinar se a ação do AS na sinalização da embriogênese de $A$. angustifolia é ligada à degradação de ERO ou se o AS promove aumento da quantidade destas enzimas que as degradam. A adição de GSNO ao meio de cultura promoveu aumento no conteúdo de NO, contudo, diminuiu a quantidade de ERO. O aumento de ERO acompanha o aumento da taxa de embriogênese somática de espécies como $A$. adsurgens (Luo et al., 2001), sugere-se que sejam utilizados doadores de peróxido de hidrogênio junto a doadores de NO para aumentar a produção de ERO. A análise da expressão do gene AaSERK1 apresentou diminuição nos níveis de transcrição após quatro horas de incubação na menor concentração de AS $(0,1 \mathrm{mM})$, sugerindo que um período de incubação eficaz para culturas embriogênicas seria entre quatro e dezesseis horas. Uma nova análise da expressão de AaSERK1 neste período seria relevante para determinação do tempo adequado de incubação das culturas embriogênicas.

Os resultados do presente trabalho são inéditos e fundamentais para uma melhor compreensão do envolvimento e sinalização do AS durante o processo de embriogênese. A realização deste trabalho complementa os estudos existentes ao longo de vários anos relativos à embriogênese zigótica e somática no sistema $A$. 
angustifolia. Assim, os resultados obtidos podem contribuir para a elucidação e otimização dos protocolos de embriogênese somática. 


\section{RESUMO}

Bueno, CA. Ácido salicílico como sinalizador durante a embriogênese de Araucaria angustifolia (Bert. O Ktze). 2014. 83p. Dissertação (Mestrado) - Instituto de Biociências, Universidade de São Paulo.

A Araucaria angustifolia é uma conífera nativa do Brasil que apresenta sementes recalcitrantes. Devido a sua importância econômica, foi intensamente explorada ao longo dos anos, encontrando-se atualmente classificada como espécie em perigo crítico de extinção pela International Union for Conservation of Nature. A embriogênese somática apresenta-se como uma ferramenta biotecnológica de grande valia na propagação de espécies recalcitrantes e de difícil propagação, com aplicação em programas de conservação, reflorestamento, e melhoramento genético vegetal. Estudos comparativos dos processos de embriogênese somática e zigótica têm permitido o conhecimento dos fatores bioquímicos, fisiológicos e genéticos que controlam o desenvolvimento do embrião, e o estabelecimento as condições artificiais para o correto desenvolvimento embrionário in vitro. $\mathrm{O}$ objetivo deste trabalho foi estudar a participação do ácido salićlico como sinalizador do processo de embriogênese zigótica e somática em $A$. angustifolia. Para tanto foi determinado o conteúdo de ácido salicílico livre e conjugado ao longo da embriogênese zigótica, e o efeito de sua suplementação em culturas embriogênicas com diferentes potenciais para a maturação. Para a embriogênese somática, a presença do ácido salicílico foi correlacionada com a geração de óxido nítrico e espécies reativas de oxigênio , e com a expressão do gene "Somatic Embryogenesis Receptor Kinase" (AaSERK). Os resultados obtidos demonstram que: a) ocorre um maior conteúdo de ácido salicílico na forma livre e conjugada nas etapas iniciais da embriogênese zigótica; b) a suplementação de ácido salicílico, nas concentrações de 0,5 a $2 \mathrm{mM}$, inibiram a indução de culturas embriogênicas; c) culturas embriogênicas incubadas em ácido salicílico apresentaram redução da síntese endógena de espécies reativas de oxigênio e aumento no conteúdo de óxido nítrico; d) a redução de espécies reativas de oxigênio indicou uma relação dose dependente com o ácido salicílico; e) a adição de um doador de óxido nítrico e um sequestrador inibiram a produção de espécies reativas de oxigênio; f) a expressão do gene AaSERK atingiu o maior nível no período de quatro horas de incubação em $0,1 \mathrm{mM}$ de AS.

Palavras-chave: Araucaria angustifolia, embriogênese, ácido salicílico, espécies reativas de oxigênio, óxido nítrico. 
ABSTRACT- Araucaria angustifolia is a conifer native of Brazil with recalcitrant seeds. Due to its economic importance, the exploration has been extensively over the years, currently this specie is classified as critically endangered by the International Union for Conservation of Nature. Somatic embryogenesis is presented as a biotechnological tool of great value in the propagation of recalcitrant species and difficult to spread, with applications in conservation, reforestation programs, and plant breeding. Comparative studies of the processes of zygotic and somatic embryogenesis has allowed the knowledge of biochemical, physiological and genetic factors that control embryo development, and the establishment artificial conditions for proper embryonic development in vitro. The objective of this work was to study the role of salicylic acid as a marker of zygotic embryogenesis and somatic process in A. angustifolia. Thus, we determined the content of free salicylic acid and conjugated along the zygotic embryogenesis, and the effect of their supplementation with different potential embryogenic cultures for maturation. For somatic embryogenesis, the presence of salicylic acid was correlated with the generation of nitric oxide, reactive oxygen species and in the gene expression "Somatic embryogenesis Receptor Kinase" (AaSERK). The results show that: a) there is an increased content of salicylic acid in free and conjugated form in the initial stages of zygotic embryogenesis; b) salicylic acid supplementation, in concentrations from 0.5 to $2 \mathrm{mM}$, inhibited the induction of embryogenic cultures; c) embryos incubated in salicylic acid decreased endogenous synthesis of reactive oxygen species and increase in content of nitric oxide; d) the reduction of reactive oxygen species indicated a dose-dependent relationship with salicylic acid; e) the addition of a nitric oxide donor and a kidnapper inhibited the production of reactive oxygen species; f) the expression of the gene AaSERK reached the highest level in four hours of incubation in $0.1 \mathrm{mM}$ AS.

Keywords: Araucaria angustifolia, embryogenesis, salicylic acid, reactive oxygen species, nitric oxide. 


\section{REFERÊNCIAS BIBLIOGRÁFICAS}

Abreu ME \& Munné-Bosch S (2009) Salicylic acid deficiency in NahG transgenic lines and sid2 mutants increases seed yield in the annual plant Arabidopsis thaliana. Journal of experimental botany, 60(4), 1261-1271.

Agami RA \& Mohamed GF (2013) Exogenous treatment with indole-3-acetic acid and salicylic acid alleviates cadmium toxicity in wheat seedlings. Ecotoxicology and environmental safety, 94, 164-171.

Allan AC \& Fluhr R (1997) Two distinct sources of elicited reactive oxygen species in tobacco epidermal cells. The Plant Cell Online, 9(9), 1559-1572.

Andrade JBDR (2010) Efeito dos agentes de maturação, ABA, PEG e maltose, na produção de óxido nítrico e de espécies reativas de oxigênio em culturas embriogênicas de Araucaria angustifolia (Doctoral dissertation, Universidade de São Paulo).

Apel K \& Hirt H (2004) Reactive oxygen species: metabolism, oxidative stress, and signal transduction. Annu. Rev. Plant Biol., 55, 373-399.

Asadi M, Heidari MA, Kazemi M, Filinejad AR (2013) Salicylic acid induced changes in some physiological parameters in chickpea (Cicer arietinum L.) under salt stress. Journal of Agricultural Technology, 9(2), 311-316.

Ashraf M, Akram NA, Arteca RN, Foolad MR (2010) The physiological, biochemical and molecular roles of brassinosteroids and salicylic acid in plant processes and salt tolerance. Critical Reviews in Plant Sciences, 29(3), 162-190.

Astarita LV \& Guerra MP (1998) Early somatic embryogenesis in Araucaria angustifolia-induction and maintenance of embryonal-suspensor mass cultures. Brazilian Journal of Plant Physiology, 10, 113-118.

Astarita LV, Floh EIS \& Handro W (2003a) Changes in IAA, tryptophan and activity of soluble peroxidase associated with zygotic embryogenesis in Araucaria angustifolia (Brazilian pine). Plant growth regulation, 39(2), 113-118.

Astarita LV, Floh EIS \& Handro W (2003b) Changes in polyamines content associated with zygotic embryogenesis in the Brazilian pine, Araucaria angustifolia (Bert.) O. Ktze. Brazilian Journal of Botany, 26(2), 163-168. 
Astarita LV, Floh EIS \& Handro W (2003c) Astarita, L. V., Floh, E. I. S., \& Handro, W. (2003). Free amino acid, protein and water content changes associated with seed development in Araucaria angustifolia. Biologia Plantarum, 47(1), 53-59.

Attree SM \& Fowke LC (1993) Embryogeny of gymnosperms: advances in synthetic seed technology of conifers. Plant Cell, Tissue and Organ Culture, 35, 1-35.

Azevedo RA, Lancien M, Lea PJ (2006) The aspartic acid metabolic pathway, an exciting and essential pathway in plants. Amino acids, 30(2), 143-162.

Bagheri MZ (2014) The effect of maize priming on germination characteristics, catalase and peroxidase enzyme activity, and total protein content under salt stress. International Journal of Biosciences (IJB), 4(2), 104-112.

Bai X, Yang L, Tian M, Chen J, Shi J, Yang Y, Hu X (2011) Nitric oxide enhances desiccation tolerance of recalcitrant Antiaris toxicaria seeds via protein Snitrosylation and carbonylation. PLoS One, 6(6), e20714.

Balbuena T, Silveira V, Junqueira M, Santa-Catarina C, Scheveschenko A, Floh EIS (2009) Changes in the 2-DE protein profile during zygotic embryogenesis in the Brazilian Pine (Araucaria angustifolia). Journal of proteomics, 72(3), 337352.

Baron K, Stasolla C (2008) The role of polyamines during in vivo and in vitro development. In Vitro Cellular \& Developmental Biology-Plant, 44(5), 384-395.

Bartels S, Anderson JC, Besteiro MAG, Carreri A, Hirt H, Buchala A, Ulm R (2009) MAP kinase phosphatase 1 and protein tyrosine phosphatase 1 are repressors of salicylic acid synthesis and SNC1-mediated responses in Arabidopsis. The Plant Cell Online, 21(9), 2884-2897.

Becwar MR, Nagmani R, Wann SR (1990) Initiation of embryogenic cultures and somatic embryo development in loblolly pine (Pinus taeda).Canadian Journal of Forest Research, 20(6), 810-817.

Beligni MV \& Lamattina L (1999) Nitric oxide protects against cellular damage produced by methylviologen herbicides in potato plants. Nitric Oxide,3(3), 199208.

Belmonte MF, Ambrose SJ, Ross AR, Abrams SR, Stasolla C (2006) Improved 
development of microspore derived embryo cultures of Brassica napus cv Topaz following changes in glutathione metabolism. Physiologia Plantarum, 127(4), 690-700.).

Belmonte MF, Donald G, Reid DM, Yeung EC, Stasolla C (2005) Alterations of the glutathione redox state improve apical meristem structure and somatic embryo quality in white spruce (Picea glauca). Journal of experimental botany, 56(419), 2355-2364.

Berglund T \& Ohlsson AB (1995) Defensive and secondary metabolism in plant tissue cultures, with special reference to nicotinamide, glutathione and oxidative stress. Plant cell, tissue and organ culture, 43(2), 137-145.

Bewley JD \& Black M (1994) Seeds: Physiology of development and germination. Plenum Press, New York, pp. 341.

Bezrukova MV, Sakhabutdinova R, Fatkhutdinova RA, Kyldiarova I, Shakirova F (2001) The role of hormonal changes in protective action of salicylic acid on growth of wheat seedlings under water deficit. Agrochemiya (Russ), 2, 51-54.

Bonga JM, Klimaszewska KK, Von Aderkas P (2010) Recalcitrance in clonal propagation, in particular of conifers. Plant Cell, Tissue and Organ Culture (PCTOC), 100(3), 241-254.

Bouchereau A, Aziz A, Larher F, Martin-Tanguy J (1999) Polyamines and environmental challenges: recent development. Plant Sci, 140, 103-125.

Bourne DJ, Barrow KD, Milborrow BV (1991) Salicyloylaspartate as an endogenous component in the leaves of Phaseolus vulgaris. Phytochemistry, 30(12), 40414044.

Cairney J, Zheng L, Cowels A (2006) Expressed sequences tags from loblolly pine embryos reveal similarities with angiosperm embryogenesis. Plant. Mol. Bio., 62, 485-501.

Caliskan G, Mechtani D, Roh JH, Kisliuk A, Sokolov AP, Azzam S, Peral I (2004) Protein and solvent dynamics: How strongly are they coupled?. The Journal of chemical physics, 121(4), 1978-1983.

Cangahuala-Inocente GC, Silveira V, Caprestano C, Floh EIS, Guerra MP (2013) 
Dynamics of Physiological and Biochemical Changes During Somatic Embryogenesis of Acca Sellowiana. In Vitro Cellular \& Developmental Biology Plant 50(2): 166-75.

Caro A \& Puntarulo S (1999) Nitric oxide generation by soybean embryonic axes. Possible effect on mitochondrial function. Free radical research, 31, S205-12.

Casson S, Lindsey K (2006) The turnip mutant of Arabidopsis reveals that LEAFY COTYLEDON1 expression mediates the effects of auxin and sugars to promote embryonic cell identity. Plant physiology, 142(2), 526-541.

Chalupa V (1985) Somatic embryogenesis and plantlet regeneration from cultured immature and mature embryos of Picea abies (L.) Karst. Commun. Inst. For. Cech, 14, 57-63.

Chen H, Xue L, Chintamanani S, Germain H, Lin H, Cui H, Zhou JM (2009) ETHYLENE INSENSITIVE3 and ETHYLENE INSENSITIVE3-LIKE1 repress SALICYLIC ACID INDUCTION DEFICIENT2 expression to negatively regulate plant innate immunity in Arabidopsis. The Plant Cell Online, 21(8), 2527-2540.

Chen Z, Silva H, Klessig DF (1993) Active oxygen species in the induction of plant systemic acquired resistance by salicylic acid. Science, 262(5141), 1883-1886.

Cleland CF \& Ajami A (1974) Identification of the flower-inducing factor isolated from aphid honeydew as being salicylic acid. Plant Physiology, 54(6), 904-906.

Cleland CF, Tanaka O, Feldman LJ (1982) Influence of plant growth substances and salicylic acid on flowering and growth in the Lemnaceae (duckweeds). Aquatic Botany, 13, 3-20.

Corpas FJ, Barroso JB, Carreras A, Valderrama R, Palma JM, León AM, del Río, LA (2006) Constitutive arginine-dependent nitric oxide synthase activity in different organs of pea seedlings during plant development. Planta, 224(2), 246254.

Correa-Aragunde N, Graziano M, Chevalier C, Lamattina L (2006) Nitric oxide modulates the expression of cell cycle regulatory genes during lateral root formation in tomato. Journal of Experimental Botany, 57(3), 581-588.

Davies PJ (1995) The plant hormones: their nature, occurrence, and functions. In Plant 
hormones (pp. 1-12). Springer Netherlands.

Dean JV, Mills JD (2004) Uptake of salicylic acid 2-O- $\beta$-D-glucose into soybean tonoplast vesicles by an ATP-binding cassette transporter-type mechanism. Physiologia plantarum, 120(4), 603-612.

Dean JV, Mohammed LA, Fitzpatrick, T (2005) The formation, vacuolar localization, and tonoplast transport of salicylic acid glucose conjugates in tobacco cell suspension cultures. Planta, 221(2), 287-296.

Delledonne M (2005) NO news is good news for plants. Current opinion in plant biology, 8(4), 390-396.

Di Rienzo JA (2009) Statistical Software for the Analysis of Experiments of Functional Genomics. Argentina: RDNDA. http://sites. google. com/site/fgStatistics.

Dietz KJ \& Scheibe R (2004) Redox regulation: an introduction. Physiologia plantarum, 120(1), 1-3.

dos Santos ALW, Gueddarri NE, Wiedholteher N \& Moerschbacher BM (2006) Protein expression during seed development in Araucaria angustifolia: transient accumulation of class IV chitinases and arabinogalactan proteins. Physiologia Plantarum, 127(1), 138-148.

dos Santos ALW, Steiner N, Guerra MP, Zoglauer K \& Moerschbacher BM (2008) Somatic embryogenesis in Araucaria angustifolia. Biologia Plantarum, 52(1), 195-199.

Du L, Ali GS, Simons KA, Hou J, Yang T, Reddy ASN, Poovaiah BW (2009) $\mathrm{Ca} 2+/$ calmodulin regulates salicylic-acid-mediated plant immunity. Nature, 457(7233), 1154-1158.

Durner J \& Klessig DF (1995) Inhibition of ascorbate peroxidase by salicylic acid and 2, 6-dichloroisonicotinic acid, two inducers of plant defense responses. Proceedings of the National Academy of Sciences, 92(24), 1131211316.

Durner J \& Klessig DF (1996) Salicylic acid is a modulator of tobacco and mammalian catalases. Journal of Biological Chemistry, 271(45), 28492-28501.

Durrant WE \& Dong X (2004) Systemic acquired resistance. Annu. Rev. 
Phytopathol., 42, 185-209.

Durzan D J \& Gupta PK (1987) Somatic embryogenesis and polyembryogenesis in Douglas-fir cell suspension cultures. Plant Science, 52(3), 229-235.

Durzan DJ \& Pedroso CM (2002) Nitric oxide and reactive nitrogen oxide species in plants. Biotechnology and Genetic Engineering Reviews, 19(1), 293-338.

Durzan DJ (2008) Monozygotic cleavage polyembryogenesis and conifer tree improvement. Cytology and genetics, 2, 159-173.

Elbl P, Lira BS, Andrade SCS, Jo L, dos Santos ALW, Coutinho LL, Rossi M (2014) Comparative transcriptome analysis of early somatic embryo formation and seed development in Brazilian pine, Araucaria angustifolia (Bertol.) Kuntze. Plant Cell, Tissue and Organ Culture (PCTOC), 1-13.

Elhiti M, Hebelstrup KH, Wang A, Li C, Cui Y, Hill RD, Stasolla C (2013) Function of type-2 Arabidopsis hemoglobin in the auxin mediated formation of embryogenic cells during morphogenesis. The Plant Journal, 74(6), 946-958.

Erdei L \& Kolbert Z (2008) Nitric oxide as a potent signalling molecule in plants. Acta Biol Szeged, 52, 1-5.

Farias-Soares F L, Steiner N, Schmidt EC, Pereira MLT, Rogge-Renner GD, Bouzon ZL, Floh EIS, Guerra MP (2014) The Transition of Proembryogenic Masses to Somatic Embryos in Araucaria Angustifolia (Bertol.) Kuntze Is Related to the Endogenous Contents of IAA, ABA and Polyamines. Acta Physiologiae Plantarum, 36(7), 1853-65.

Fariduddin Q, Hayat S, Ahmad A (2003) Salicylic acid influences net photosynthetic rate, carboxylation efficiency, nitrate reductase activity, and seed yield in Brassica juncea. Photosynthetica, 41(2), 281-284.

Feher A, Pasternak TP, Dudits D (2003) Transition of somatic plant cells to an embryogenic state. Plant Cell, Tissue and Organ Culture, 74(3), 201-228.

Filonova LH, Bozhkov PV, von Arnold S (2000) Developmental pathway of somatic embryogenesis in Picea abies as revealed by time-lapse tracking. $J$ Exp Bot, 51(343), 249-64.

Floh IES (2007) Marcadores bioquímicos e moleculares para estudo da morfogênese 
in vitro. Revista Brasileira de Horticultura Ornamental, 13, 1992-2001.

Foreman J, Demidchik V, Bothwell JH, Mylona P, Miedema H, Torres MA, Dolan, L (2003) Reactive oxygen species produced by NADPH oxidase regulate plant cell growth. Nature, 422(6930), 442-446.

Galston AW, Sawhey RK (1990) Polyamines and plant physiology. Plant Physiol., 94(2), 406-10.

Ganesan M \& Jayabalan N (2004) Evaluation of haemoglobin (erythrogen): for improved somatic embryogenesis and plant regeneration in cotton (Gossypium hirsutum L. cv. SVPR 2). Plant cell reports, 23(4), 181-187.

Gill SS \& Tuteja N (2010) Reactive oxygen species and antioxidant machinery in abiotic stress tolerance in crop plants. Plant Physiology and Biochemistry, 48(12), 909-930.

Gou X, Yin H, He K, Du J, Yi J, Xu S, Li J (2012) Genetic evidence for an indispensable role of somatic embryogenesis receptor kinases in brassinosteroid signaling. PLoS genetics, 8(1), e1002452.

Grün S, Lindermayr C, Sell S, Durner J (2006) Nitric oxide and gene regulation in plants. Journal of Experimental Botany, 57(3), 507-516.

Guerra MP, Silveira V, Santos ALW, Astarita LV, Nodari RO (2000) Somatic embryogenesis in Araucaria angustifolia (BERT) O. KTZE. In Somatic embryogenesis in woody plants (pp. 457-478). Springer Netherlands.

Guerra MP, Torres AC, Teixeira JB (1999) Embriogênese somática e sementes sintéticas. Cultura de tecidos e transformação genética de plantas.

Haines RJ \& Prakash N (1980) Proembryo development and suspensor elongation in Araucaria Juss. Australian Journal of Botany, 28(6), 511-522.

Hakman I \& Oliviusson P (2002) High expression of putative aquaporin genes in cells with transporting and nutritive functions during seed development in Norway spruce (Picea abies). Journal of Experimental Botany, 53, 639-649.

Halperin W (1966) Alternative morphogenetic events in cell suspensions. American Journal of Botany, 53(5), 443-453. 
Hayat Q, Hayat S, Irfan M, Ahmad A (2010) Effect of exogenous salicylic acid under changing environment: a review. Environmental and Experimental Botany, 68(1), 14-25.

Hayat S, Ali B, Ahmad A (2007) Salicylic acid: Biosynthesis, Metabolism and Physiological Role in Plants, Salicylic acid: a plant hormone pp. 1-14.

He K, Gou X, Yuan T, Lin H, Asami T, Yoshida S, Li J (2007) BAK1 and BKK1 regulate brassinosteroid-dependent growth and brassinosteroid-independent cell-death pathways. Current Biology, 17(13), 1109-1115.

Hecht V, Vielle-Calzada JP, Hartog MV, Schmidt ED, Boutilier K, Grossniklaus U, de Vries SC (2001) The Arabidopsis SOMATIC EMBRYOGENESIS RECEPTOR KINASE 1 gene is expressed in developing ovules and embryos and enhances embryogenic competence in culture. Plant Physiology, 127(3), 803-816.

Hegedüs A, Erdei S, Horváth G (2001) Comparative studies of H2O2 detoxifying enzymes in green and greening barley seedlings under cadmium stress. Plant Science, 160(6), 1085-1093.

Hellemans J, Mortier G, De Paepe A, Speleman F, Vandesompele J (2007) qBase relative quantification framework and software for management and automated analysis of real-time quantitative PCR data. Genome biology, 8(2), R19.

Högberg KA, Bozhkov PV, von Arnold S (2003) Early selection improves clonan performance and reduces intraclonal variation of Norway spruce plants propagated by somatic embryogenesis. Tree Physiol, 23, 211-6.

Hsu YT \& Kao CH (2004) Cadmium toxicity is reduced by nitric oxide in rice leaves. Plant Growth Regulation, 42(3), 227-238.

Hu H, Xiong L, Yang Y (2005) Rice SERK1 gene positively regulates somatic embryogenesis of cultured cell and host defense response against fungal infection. Planta, 222(1), 107-117.

Huang J, Gu M, Lai Z, Fan B, Shi K, Zhou YH, Chen Z (2010) Functional analysis of the Arabidopsis PAL gene family in plant growth, development, and response to environmental stress. Plant Physiology, 153(4), 1526-1538. 
Huang X, Huang XL, Xiao W, Zhao JT, Dai XM, Chen YF, Li X J (2007) Highly efficient Agrobacterium-mediated transformation of embryogenic cell suspensions of Musa acuminata cv. Mas (AA) via a liquid co-cultivation system. Plant cell reports, 26(10), 1755-1762.

Hutchinson MJ \& Saxena PK (1996) Acetylsalicylic acid enhances and synchronizes thidiazuron-induced somatic embryogenesis in geranium (Pelargonium $x$ hortorum Bailey) tissue cultures. Plant Cell Reports, 15(7), 512-515.

Imai H \& Nakagawa Y (2003) Biological significance of phospholipid hydroperoxide glutathione peroxidase (PHGPx, GPx4) in mammalian cells. Free Radical Biology and Medicine, 34(2), 145-169.

Jain SM \& Ishii K (1998) Recent advances in somatic embryogenesis in forest trees. Recent advances in biotechnology for conservation and management.(SH Mantell, S. Bruns, C. Tragardh \& AM Viana, eds.). International Foundation for Science, Stockholm, 214-231.

Jiménez VM (2005) Involvement of plant hormones and plant growth regulators on in vitro somatic embryogenesis. Plant Growth Regulation, 47(2-3), 91-110.

Jin J, Zhang H, Kong L, Gao G, Luo J (2013) PlantTFDB 3.0: a portal for the functional and evolutionary study of plant transcription factors. Nucleic acids research, gkt1016.

Jo L (2012) Estabelecimento de marcadores bioquímicos para embriogênese somática em Araucaria angustifolia (Doctoral dissertation, Universidade de São Paulo).

Jo L, Dos Santos AL, Bueno CA, Barbosa HR, Floh EIS (2013) Proteomic analysis and polyamines, ethylene and reactive oxygen species levels of Araucaria angustifolia (Brazilian pine) embryogenic cultures with different embryogenic potential. Tree physiology, tpt102.

Jurzita G (1987) Anatomie der Samenpflanzen. Georg Thieme Verlag, Stuttgart Kang D, Gho YS, Suh M \& Kang C (2002) Highly sensitive and fast protein detection with coomassie brilliant blue in sodium dodecyl sulphatepolyacrylamide gel electrophoresis. Bull. Korean Chem. Soc., 23(11), 15111512.

Kachroo P, Yoshioka K, Shah J, Dooner HK, Klessig DF (2000) Resistance to turnip 
crinkle virus in Arabidopsis is regulated by two host genes and is salicylic acid dependent but NPR1, ethylene, and jasmonate independent. The Plant Cell Online, 12(5), 677-690.

Kacperska A (2004) Sensor types in signal transduction pathways in plant cells responding to abiotic stressors: do they depend on stress intensity?.Physiologia Plantarum, 122(2), 159-168.

Kalachova T, lakovenko O, Kretinin S, Kravets V (2013) Involvement of phospholipase D and NADPH-oxidase in salicylic acid signaling cascade. Plant Physiology and Biochemistry, 66, 127-133.

Kang SM, Min JY, Kim YD, Kang YM, Park DJ, Jung HN, Choi MS (2006) Effects of methyl jasmonate and salicylic acid on the production of bilobalide and ginkgolides in cell cultures of Ginkgo biloba. In Vitro Cellular \& Developmental Biology-Plant, 42(1), 44-49.

Khan W, Prithiviraj B, Smith DL (2003) Photosynthetic responses of corn and soybean to foliar application of salicylates. Journal of plant physiology, 160(5), 485-492.

Khokon M, Okuma EIJI, Hossain MA, Munemasa S, Uraji M, Nakamura Y, Murata Y (2011) Involvement of extracellular oxidative burst in salicylic acid-induced stomatal closure in Arabidopsis. Plant, cell \& environment, 34(3), 434-443.

Kleine-Vehn J, Friml J (2008) Polar targeting and endocytic recycling in auxindependent plant development. Annual review of cell and developmental biology, 24, 447-473.

Klimaszewska K, Overton C, Stewart D, Rutledge RG (2011) Initiation of somatic embryos and regeneration of plants from primordial shoots of 10-year-old somatic white spruce and expression profiles of 11 genes followed during the tissue culture process. Planta, 233(3), 635-647.

Kong L, Attree SM, Evan DE, Binarova P, Yeung EC, Fowke LC (1999) Somatic embryogenesis in white spruce: studies of embryo development and cell biology. In Somatic embryogenesis in woody plants (pp. 1-28). Springer Netherlands.

Kong L, Attree SM, Fowke LC (1997) Changes of endogenous hormone levels in 
developing seeds, zygotic embryos and megagametophytes in Picea glauca. Physiologia Plantarum, 101(1), 23-30.

Kopyra M \& Gwóźdź EA (2003) Nitric oxide stimulates seed germination and counteracts the inhibitory effect of heavy metals and salinity on root growth of Lupinus luteus. Plant Physiology and Biochemistry, 41(11), 1011-1017.

Kováčik J, Klejdus B, Hedbavny J, Štork F, Bačkor M (2009) Comparison of cadmium and copper effect on phenolic metabolism, mineral nutrients and stress-related parameters in Matricaria chamomilla plants. Plant and soil, 320(12), 231-242.

Lam HM, Coschigano K, Schultz C, Melo-Oliveira R, Tjaden G, Oliveira I, Coruzzi G (1995) Use of Arabidopsis mutants and genes to study amide amino acid biosynthesis. The Plant Cell, 7(7), 887.

Lamb C \& Dixon RA (1997) The oxidative burst in plant disease resistance. Annual review of plant biology, 48(1), 251-275.

Larque-Saavedra A (1979) Stomatal closure in response to acetylsalicylic acid treatment. Zeitschrift für Pflanzenphysiologie, 93(4), 371-375.

Laspina NV, Groppa MD, Tomaro ML, Benavides MP (2005) Nitric oxide protects sunflower leaves against Cd-induced oxidative stress. Plant Science, 169(2), 323-330.

Laux T \& Jurgens G (1997) Embryogenesis: a new start in life. The Plant Cell, 9(7), 989.

Laxalt AM, Raho N, Have AT, Lamattina L (2007) Nitric oxide is critical for inducing phosphatidic acid accumulation in xylanase-elicited tomato cells. Journal of Biological Chemistry, 282(29), 21160-21168.

Lee DH, Choi HW, Hwang BK (2011) The pepper E3 ubiquitin ligase RING1 gene, CaRING1, is required for cell death and the salicylic acid-dependent defense response. Plant physiology, 156(4).

Leshem Y A Y \& Haramaty E (1996) The Characterization and Contrasting Effects of the Nitric Oxide Free Radical in Vegetative Stress and Senescence of Pisum sativum Linn. Foliage. Journal of Plant Physiology, 148(3), 258-263. 
Leslie CA \& Romani RJ (1988) Inhibition of ethylene biosynthesis by salicylic acid. Plant physiology, 88(3), 833-837.

Leung $\mathbf{J}$, Giraudat $\mathbf{J}$ (1998) Abscisic acid signal transduction. Annual review of plant biology, 49(1), 199-222.

Lichtenthaler HK (1998) The stress concept in plants: an introduction. Annals of the New York Academy of Sciences, 851(1), 187-198.

Ljung K, Hull AK, Kowalczyk M, Marchant A, Celenza J, Cohen JD, Sandberg G (2002) Biosynthesis, conjugation, catabolism and homeostasis of indole-3acetic acid in Arabidopsis thaliana. In Auxin Molecular Biology, pp. 249-272.

Lopes AS, Lane M, Thompson JG (2010) Oxygen consumption and ROS production are increased at the time of fertilization and cell cleavage in bovine zygotes. Human reproduction, deq221.

Lopez-Delgado HA, Scott IM, Mora-Herrera ME (2007) Stress and antistress effects of salicylic acid and acetyl salicylic acid on potato culture technology. Salicylic acid: a plant hormone, pp. 163-195.

Luo JP, Jiang ST, Pan LJ (2001) Enhanced somatic embryogenesis by salycilic acid of Astragalus adsurgens Pall: relationship with $\mathrm{H} 2 \mathrm{O} 2$ production and $\mathrm{H} 2 \mathrm{O} 2$ production and H2O2-metabolizing enzyme activities. Plant Science, 161, 125132.

Ma X, Bucalo K, Determann RO, Cruse-Sanders JM, Pullman GS (2012) Somatic embryogenesis, plant regeneration and cryo- preservation for Torreya taxifolia, a highly endangered coniferous species. In Vitro Cell Dev Biol Plant, 48, 324334.

Mahalingam R \& Fedoroff N (2003) Stress response, cell death and signalling: the many faces of reactive oxygen species. Physiologia Plantarum, 119(1), 56-68.

Mehdy MC, Sharma YK, Sathasivan K, Bays NW (1996) The role of activated oxygen species in plant disease resistance. Physiologia Plantarum, 98(2), 365-374.

Métraux JP (2002) Recent breakthroughs in the study of salicylic acid biosynthesis. Trends in plant science, 7(8), 332-334.

Miura K \& Tada Y (2014) Regulation of water, salinity, and cold stress responses by 
salicylic acid. Frontiers in plant science, 5.

Mordhorst AP, Charbit, E, de Vries, SC (2005) Somatic embryogenesis.Plant development and biotechnology. Eds. Trigiano R, Gray R. CRC Press LLC Boca Raton, Florida, USA, 201-209.

Mordhorst AP, Toonen MA, de Vries SC, Meinke D (1997) Plant embryogenesis. Critical Reviews in Plant Sciences, 16(6), 535-576.

Moreau M, Lindermayr C, Durner J, Klessig DF (2010) NO synthesis and signaling in plants-where do we stand?. Physiologia Plantarum, 138(4), 372-383.

Mulgund GS, Meti NT, Malabadi RB, Nataraja K, Kumar, SV (2012) Role of salicyclic acid on conifer somatic embryogenesis. Research in Biotechnology, 3(2).

Nagamiya K, Motohashi T, Nakao K, Prodhan SH, Hattori E, Hirose S, Komamine A (2007) Enhancement of salt tolerance in transgenic rice expressing an Escherichia coli catalase gene, katE. Plant Biotechnology Reports, 1(1), 49-55.

Nagmani R, Bonga JM (1985) Embryogenesis in subcultured callus of Larix decidua. Canadian Journal of Forest Research, 15(6): 1088-1091.

Nambara E, Marion-Poll A (2005) Abscisic acid biosynthesis and catabolism. Annu. Rev. Plant Biol., 56, 165-185.

Neill S, Barros R, Bright J, Desikan R, Hancock J, Harrison J, Wilson I (2008) Nitric oxide, stomatal closure, and abiotic stress. Journal of experimental botany, 59(2), 165-176.

Neill SJ, Desikan R, Clarke A, Hurst RD Hancock JT (2002) Hydrogen peroxide and nitric oxide as signalling molecules in plants. Journal of experimental botany, 53(372), 1237-1247.

Nolan KE, Irwanto RR, Rose RJ (2003) Auxin up-regulates MtSERK1 expression in both Medicago truncatula root-forming and embryogenic cultures. Plant Physiology, 133(1), 218-230.

Nolan KE, Song Y, Liao S, Saeed NA, Zhang X, Rose RJ (2014) An Unusual Abscisic Acid and Gibberellic Acid Synergism Increases Somatic Embryogenesis, Facilitates Its Genetic Analysis and Improves Transformation in Medicago truncatula. PLoS ONE 9(6): e99908. 
Nordberg J \& Arnér ES (2001) Reactive oxygen species, antioxidants, and the mammalian thioredoxin system. Free radical biology and medicine, 31(11), 1287-1312.

Olson PD \& Varner JE (1993) Hydrogen peroxide and lignification. The Plant Journal, 4(5), 887-892.

Orenes A, Martínez-Moreno JM, Calderón AA, Ferrer MA (2013) Changes in phenolic metabolism in salicylic acid-treated shoots of Cistus heterophyllus. Plant Cell, Tissue and Organ Culture (PCTOC), 113(3), 417-427.

Orozco-Cárdenas M L \& Ryan CA (2002) Nitric oxide negatively modulates wound signaling in tomato plants. Plant Physiology, 130(1), 487-493.

Osti RZ, Andrade JBR, Souza JP, Silveira V, Balbuena TS, Guerra MP, Franco DW, Floh EIS, Santa-Catarina C (2010) Nitrosyl ethylenediaminetetraacetate ruthenium (II) complex promotes cellular growth and could be used as nitric oxide donor in plants. Plant science, 178(5), 448-453.

Ötvös K, Pasternak TP, Miskolczi P, Domoki M, Dorjgotov D, Bottka S, Fehér A (2005) Nitric oxide is required for, and promotes auxin-mediated activation of, cell division and embryogenic cell formation but does not influence cell cycle progression in alfalfa cell cultures. The Plant Journal, 43(6), 849-860.

Palovaara J \& Hakman I (2008) Conifer WOX-related homeodomain transcription factors, developmental consideration and expression dynamic of WOX2 during Picea abies somatic embryogenesis. Plant molecular biology,66(5), 533-549.

Pan Z, Guan R, Zhu S, Deng X (2009) Proteomic analysis of somatic embryogenesis in Valencia sweet orange (Citrus sinensis Osbeck). Plant cell reports, 28(2), 281-289.

Pancheva TV, Popova LP, Uzunova AN (1996) Effects of salicylic acid on growth and photosynthesis in barley plants. Journal of Plant Physiology, 149(1), 57-63.

Park YK, Koo MH, Abreu JAS (1998) Antimicrobial activity of propolis on oral microrganism. Current Microbiol, 34(1), 24-28.

Pasternak T, Prinsen E, Ayaydin F, Miskolczi P, Potters G, Asard H, Van Onckelen H, Dudits D, Fehér A (2002) The role of auxin, pH, and stress in the 
activation of embryogenic cell division in leaf protoplast-derived cells of alfalfa. Plant Physiology, 129(4), 1807-1819.

Pastore S, Mascia F, Mariani V, Girolomoni G (2007) The epidermal growth factor receptor system in skin repair and inflammation. Journal of Investigative Dermatology, 128(6), 1365-1374.

Pérez-Núñez MT, Souza R, Sáenz L, Chan JL, Zuniga-Aguilar JJ, Oropeza C (2009) Detection of a SERK-like gene in coconut and analysis of its expression during the formation of embryogenic callus and somatic embryos. Plant cell reports, 28(1), 11-19.

Pius J, George L, Eapens S, Rao PS (1993) Enhanced plant generation in pearl millet (Pennisetum americanum) by ethylene inhibitors and cefotaxime. Plant cell, tissue and organ culture, 32(1), 91-96.

Popova L, Pancheva T, Uzunova A (1997) Salicylic acid: properties, biosynthesis and physiological role. Bulg. J. Plant Physiol, 23, 85-93.

Pullman GS, Bucalo K (2014) Pine somatic embryogenesis: analyses of seed tissue and medium to improve protocol development. New Forests, 45(3), 353-377.

Quiroz-Figueroa FR, Méndez-Zeel M, Larqué-Saavedra, Loyola-Vargas (2001) Picomolar concentrations of salicylates induce cellular growth and enhance somatic embryogenesis in Coffea arabica tissue culture. Plant cell reports, 20(8), 679-684.

Quiroz-Figueroa FR, Rojas-Herrera R, Galaz-Avalos RM, Loyola-Vargas VM (2006) Embryo production through somatic embryogenesis can be used to study cell differentiation in plants. Plant Cell, Tissue and Organ Culture, 86(3), 285-301.

Rajjou L, Belghazi M, Huguet R, Robin C, Moreau A, Job C, Job D (2006) Proteomic investigation of the effect of salicylic acid on Arabidopsis seed germination and establishment of early defense mechanisms. Plant physiology, 141(3), 910-923.

Raskin I (1992) Salicylate, a new plant hormone. Plant physiology, 99(3), 799.

Resende MLV (2007) Reconhecimento e transdução de sinais nas interações plantapatógeno. Summa Phytopathologica, 33, 157-60 (suplemento). 
Resende MLV, Salgado SM, Chaves ZM (2003) Espécies ativas de oxigênio na resposta de defesa de plantas a patógenos. Fitopatologia Brasileira, 28(2), 123130.

Rivas-San Vicente M \& Plasencia J (2011) Salicylic acid beyond defence: its role in plant growth and development. Journal of experimental botany, 62(10), 33213338.

Rock CD \& Quatrano RS (1995) The role of hormones during seed development. In Plant hormones (pp. 671-697). Springer Netherlands.

Rolletschek H, Weschke W, Weber H, Wobus U, Borisjuk L (2004) Energy state and its control on seed development: starch accumulation is associated with high ATP and steep oxygen gradients within barley grains. Journal of experimental Botany, 55(401), 1351-1359.

Romero-Puertas MC, Perazzolli M, Zago ED, Delledonne M (2004) Nitric oxide signalling functions in plant-pathogen interactions. Cellular microbiology, 6(9), 795-803.

Roux M, Schwessinger B, Albrecht C, Chinchilla D, Jones A, Holton N, Zipfel C (2011) The Arabidopsis leucine-rich repeat receptor-like kinases BAK1/SERK3 and BKK1/SERK4 are required for innate immunity to hemibiotrophic and biotrophic pathogens. The Plant Cell Online, 23(6), 2440-2455.

Ruijter JM, van der Velden S, Ilgun A (2009) LinReg PCR (11.0). Analysis of quantitative.

Sahu GK (2013) Salicylic Acid: Role in Plant Physiology and Stress Tolerance. In Molecular Stress Physiology of Plants (pp. 217-239). Springer India.

Santa-Catarina C, Hanai LR, Dornelas MC, Viana AM, Floh EIS (2004) SERK gene homolog expression, polyamines and amino acids associated with somatic embryogenic competence of Ocotea catharinensis Mez.(Lauraceae). Plant cell, tissue and organ culture, 79(1), 53-61.

Santa-Catarina C, Silveira V, Balbuena TS, Maranhão MEE, Handro W e Floh EIS (2006) IAA, ABA, polyamines and free amino acids associated with zygotic embryo development of Ocotea catharinensis. Plant growth regulation, 49(2-3), 237-247. 
Santa-Catarina C, Silveira V, Scherer GFE, Floh EIS (2007) Polyamine and nitric oxide levels relate with morphogenetic evolution in somatic embryogenesis of Ocotea catharinensis. Plant cell, tissue and organ culture, 90(1), 93-101.

Santos ALW, El-Gueddari NE, Trombotto S, Moerschebacher BM (2008) Partially acetylated chitosan oligo and polymers induce na oxidative burst in suspension cultured cells of the gymnosperm Araucaria angustifolia, Biomacromolecules, 9 (12), 3411-3415.

Santos ALW, Silveira V, Steiner N, Vidor M, Guerra MP (2002) Somatic embryogenesis in Parana pine Araucaria angustifolia (Bert.) O. Ktze. Brazilian Archives of Biology and Technology, 45(01),97-104.

Santos MO \& Aragao FJ (2009) Role of SERK genes in plant environmental response. Plant Signal Behav, 4(12), 1111-1113.

Sasaki AT, Janetopoulos C, Lee S, Charest PG, Takeda K, Sundheimer LW, Firtel RA (2007) G protein-independent Ras/PI3K/F-actin circuit regulates basic cell motility. The Journal of cell biology, 178(2), 185-191.

Šašek V, Janda M, Delage E, Puyaubert J, Guivarc'h A, López Maseda E, Ruelland E (2014) Constitutive salicylic acid accumulation in pi4kIII $\beta 1 \beta 2$ Arabidopsis plants stunts rosette but not root growth. New Phytologist.

Savona M, Mattioli R, Nigro S, Falasca G, Della Rovere F, Costantino P, Altamura M M (2012) Two SERK genes are markers of pluripotency in Cyclamen persicum Mill. Journal of experimental botany, 63(1), 471-488.

Scheler C, Durner J, Astier J (2013) Nitric oxide and reactive oxygen species in plant biotic interactions. Current opinion in plant biology, 16(4), 534-539.

Schellenbaum P, Jacques A, Maillot P, Bertsch C, Mazet F, Farine S, Walter B (2008) Characterization of VvSERK1, VvSERK2, VvSERK3 and VvL1L genes and their expression during somatic embryogenesis of grapevine (Vitis vinifera L.). Plant cell reports, 27(12), 1799-1809.

Schmidt ED, Guzzo F, Toonen MA, De Vries SC (1997) A leucine-rich repeat containing receptor-like kinase marks somatic plant cells competent to form embryos. Development, 124(10), 2049-2062. 
Schmidt L, Duh FM, Chen F, Kishida T, Glenn G, Choyke P, Zbar, B (1997) Germline and somatic mutations in the tyrosine kinase domain of the MET proto-oncogene in papillary renal carcinomas. Nature genetics, 16(1), 68-73.

Schneider EA \& Wightman F (1974) Metabolism of auxin in higher plants. Annual Review of Plant Physiology, 25(1), 487-513.

Scott IM, Clarke SM, Wood JE, Mur LA (2004) Salicylate accumulation inhibits growth at chilling temperature in Arabidopsis. Plant Physiology, 135(2), 10401049.

Senaratna T, Touchell D, Bunn E, Dixon K (2000) Acetyl salicylic acid (Aspirin) and salicylic acid induce multiple stress tolerance in bean and tomato plants. Plant Growth Regulation, 30(2), 157-161.

Shakirova FM, Sakhabutdinova AR, Bezrukova MV, Fatkhutdinova RA, Fatkhutdinova, DR (2003) Changes in the hormonal status of wheat seedlings induced by salicylic acid and salinity. Plant Science, 164(3), 317-322.

Shirano Y, Kachroo P, Shah J, Klessig DF (2002) A gain-of-function mutation in an Arabidopsis Toll Interleukin1 Receptor-Nucleotide Binding Site-Leucine-Rich Repeat type $\mathrm{R}$ gene triggers defense responses and results in enhanced disease resistance. The Plant Cell Online, 14(12), 3149-3162.

Silveira V, Floh EIS, Handro W, Guerra MP (2004) Effect of plant growth regulators on the cellular growth and levels of intracellular protein, starch and polyamines in embryogenic suspension cultures of Pinus taeda. Plant Cell, Tissue and Organ Culture, 76(1), 53-60.

Silveira V, Santa-Catarina C, Balbuena, TS, Moraes FMS, Ricart CAO, Sousa MV De, Guerra MP, H Walter, Floh EIS (2008) Endogenous abscisic acid and protein contents during seed development of Araucaria angustifolia.Biologia Plantarum, 52(1), 101-104.

Silveira V, Santa-Catarina C, Tun NN, Scherer GFE, Handro W, Guerra MP, Floh EIS (2006) Polyamine effects on the endogenous polyamine contents, nitric oxide release, growth and differentiation of embryogenic suspension cultures of Araucaria angustifolia (Bert.) O. Ktze. Plant Science, 171(1), 91-98.

Silveira V, Steiner N, Santos ALW, Nodari NO, Guerra MP (2002) Biotechnology 
tolls in Araucaria angustifolia conservation and improvement: inductive factors affecting somatic embryogenesis. Crop Breeding And Applied Biotechnology, 2, 463-470.

Singh H (1978) Embryology of gymnosperms. Berlin: Gebruder Borntraeger, 302p.Illus., key. Embryology. Geog, 1-7.

Slaymaker DH, Navarre DA, Clark D, del Pozo O, Martin GB, Klessig DF (2002) The tobacco salicylic acid-binding protein 3 (SABP3) is the chloroplast carbonic anhydrase, which exhibits antioxidant activity and plays a role in the hypersensitive defense response. Proceedings of the National Academy of Sciences, 99(18), 11640-11645.

Somleva MN, Schmidt EDL, De Vries SC (2000) Embryogenic cells in Dactylis glomerata L.(Poaceae) explants identified by cell tracking and by SERK expression. Plant Cell Reports, 19(7), 718-726.

Stasolla C (2010) Glutathione redox regulation of in vitro embryogenesis. Plant Physiology and Biochemistry, 48(5), 319-327.

Stasolla C, Belmonte MF, van Zyl L, Craig DL, Liu W, Yeung EC, Sederoff RR (2004) The effect of reduced glutathione on morphology and gene expression of white spruce (Picea glauca) somatic embryos. Journal of experimental botany, 55(397), 695-709.

Stasolla C, van Zyl L, Egertsdotter U, Craig D, Liu W, Sederoff RR (2003) The effects of polyethylene glycol on gene expression of developing white spruce somatic embryos. Plant Physiology, 131(1), 49-60.

Stasolla C, Yeung EC (2003) Recent advances in conifer somatic embryogenesis: improving somatic embryo quality. Plant Cell, Tissue and Organ Culture, 74(1), 15-35.

Steiner N (2009) Embriogênese somática em Araucaria angustifolia (Bert. O.) Kuntze, Pinus sylvestris (Linneaus) e Picea abies (Linneaus) Karsten.

Steiner N, Santa-Catarina C, Andrade JBR, Balbuena TS, Guerra MP, Handro W, Floh EIS, Silveira V (2008) Araucaria angustifolia Biotechnology - Review. Functional Plant Science and Biotechnology, 2, 20-28. 
Steiner N, Santa-Catarina C, Guerra MP, Cutri L, Dornelas MC, Floh EIS (2012) A gymnosperm homolog of SOMATIC EMBRYOGENESIS RECEPTOR-LIKE KINASE-1 (SERK1) is expressed during somatic embryogenesis. Plant Cell, Tissue and Organ Culture (PCTOC), 109(1), 41-50.

Steiner N, Vieira FN, Maldonado S, Guerra MP (2005) Effect of carbon source on morphology and histodifferentiation of Araucaria angustifolia embryogenic cultures. Brazilian Archives of Biology and Technology, 48(6), 895-903.

Sticher L, Mauch-Mani B, Métraux AJ (1997) Systemic acquired resistance. Annual review of phytopathology, 35(1), 235-270.

Sun B, Jing Y, Chen K, Song L, Chen F, Zhang L (2007) Protective effect of nitric oxide on iron deficiency-induced oxidative stress in maize (Zea mays). Journal of plant physiology, 164(5), 536-543.

Taiz L \& Zeiger E (2009) Fisiologia vegetal (Vol. 10). Universitat Jaume I.

Tanaka K, Hayashi K, Natsume M, Kamiya Y, Sakakibara H, Kawaide H, Kasahara H (2014). UGT74D1 catalyzes the glucosylation of 2-oxindole-3-acetic acid in the auxin metabolic pathway in Arabidopsis. Plant \& cell physiology, 55(1), 21828.

Tautorus TE, Attree SM, Fowke LC, Dustan DI (1989) Somatic embryogenesis from immature and mature zygotic embryos, and embryo regeneration from protoplasts in black spruce (Picea mariana Mill.). Plant Science, 67(1), 115-124.

Tautorus TE, Fowke LC, Dunstan DI (1991) Somatic embryogenesis in conifers. Canadian Journal of Botany, 69(9), 1873-1899.

Thomas T (1993) Gene expression during plant embryogenesis and germination: an overview. The Plant Cell, 5(10), 1401.

Tirani MM, Nasibi F, Kalantari, KM (2013) Interaction of salicylic acid and ethylene and their effects on some physiological and biochemical parameters in canola plants (Brassica napus L.). Photosynthetica, 51(3), 411-418.

Torres MA (2010) ROS in biotic interactions. Physiologia Plantarum, 138(4), 414-429.

Valente EM, Arena G, Torosantucci L, Gelmetti V (2012) Molecular pathways in sporadic PD. Parkinsonism \& related disorders, 18, S71-S73. 
van Esse GW, Van Mourik S, Stigter H, Colette A, Molenaar J, de Vries SC (2012) A mathematical model for BRASSINOSTEROID INSENSITIVE1-mediated signaling in root growth and hypocotyl elongation. Plant physiology, 160(1), 523-532.

Verberne MC, Brouwer N, Delbianco F, Linthorst HJM, Bol JF, Verporrte R (2002) Method for the extraction of the volatile compound salicylic acid from tobacco leaf material. Phytochemical Analysis, 13(1), 45-50.

Vestman D, Larsson E, Uddenberg D, Cairney J, Clapham D, Sundberg E, von Arnold S (2011) Important processes during differentiation and early development of somatic embryos of Norway spruce as revealed by changes in global gene expression. In BMC Proceedings, 5(7) 78. BioMed Central Ltd.

Viana VM, Tabanez AAJ, Batista JL (1997) Restoration and management of fragmented landscapes. Tropical forest remnants: ecology, management, and conservation of fragmented communities. University of Chicago Press, Chicago, 347-365.

Vlot AC, Dempsey DMA, Klessig DF (2009) Salicylic acid, a multifaceted hormone to combat disease. Annual review of phytopathology,47, 177-206.

Vogelmann K, Drechsel G, Bergler J, Subert C, Philippar K, Soll J, Hoth, S (2012) Early senescence and cell death in Arabidopsis saul1 mutants involves the PAD4-dependent salicylic acid pathway. Plant physiology, 159(4), 1477-1487.

von Arnold S, Bozhkov P, Clapham D, Dyachok J, Filonova L, Hogberg KA, Ingouff M, Wiweger M (2005) Propagation of Norway spruce via somatic embryogenesis. Plant cell, tissue and organ culture, 81(3), 323-329.

von Arnold S, Sabala I, Bozhkov P, Dyachok J \& Filanova L (2002) Developmental pathways of somatic embryogenesis. Plant Cell, Tissue and Organ Culture, 69(3), 233-249.

Ward ER, Uknes SJ, Williams SC, Dincher SS, Wiederhold DL, Alexander DC, Ryals JA (1991) Coordinate gene activity in response to agents that induce systemic acquired resistance. The Plant Cell Online, 3(10), 1085-1094.

Xu H, Zhang W, Gao Y, Zhao Y, Guo L, Wang J (2012) Proteomic analysis of embryo development in rice (Oryza sativa). Planta, 235(4), 687-701. 
Yang X \& Zhang X (2010) Regulation of somatic embryogenesis in higher plants. Critical Reviews in Plant Science, 29(1), 36-57.

Yeh M-L \& Chang WC (1987) Yeh, M. L., \& Chang, W. C. (1987). Plant regeneration via somatic embryogenesis in mature embryo-derived callus culture of Sinocalamus latiflora (Munro) McClure. Plant science, 51(1), 93-96.

Yu M, Lamattina L, Spoel SH, Loake GJ (2014) Nitric oxide function in plant biology: a redox cue in deconvolution. New Phytologist, 202(4), 1142-1156.

Zhang S, Han S, Yang W, Wei H, Zhang M, Qi L (2010) Changes in H2O2 content and antioxidant enzyme gene expression during the somatic embryogenesis of Larix leptolepis. Plant Cell, Tissue and Organ Culture, 100(1), 21-29.

Zhang Z, Li Q, Li Z, Staswick PE, Wang M, Zhu Y, He Z (2007) Dual regulation role of GH3. 5 in salicylic acid and auxin signaling during Arabidopsis-Pseudomonas syringae interaction. Plant Physiology, 145(2), 450-464.

Zimmerman JL (1993) Somatic embryogenesis: a model for early development in higher plants. The Plant Cell, 5(10), 1411. 
ANEXO I 
Determinação do efeito da concentração de promotores (GSNO) e inibidores (PTIO e L-NAME) na formação do NO intracelular nas suspensões celulares

Os ensaios para determinação da concentração de doadores e inibidores a ser utilizada apresentaram influência no conteúdo intracelular de NO com GSNO (Figura suplementar 1) e PTIO (Figura suplementar 2). A análise do inibidor L-NAME não foi eficaz para o sistema $A$. angustifolia (Figura suplementar 3).
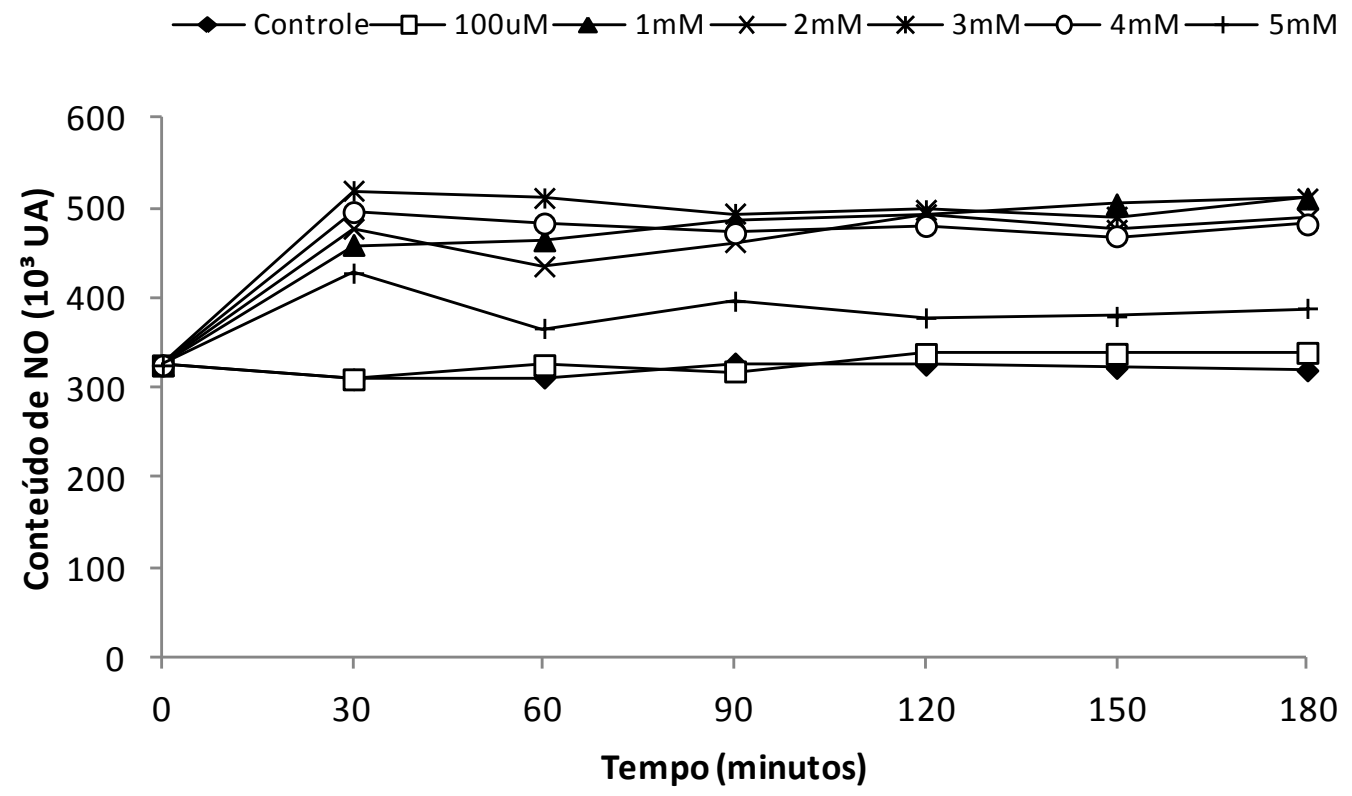

Figura suplementar 1. Conteúdo de NO intracelular em suspensões celulares de $A$. angustifolia suplementadas com diferentes concentrações de GSNO $(0 ; 0,1 ; 1 ; 2 ; 3 ; 4$ e 5 mM). Média \pm desvio padrão, $n=3$. 


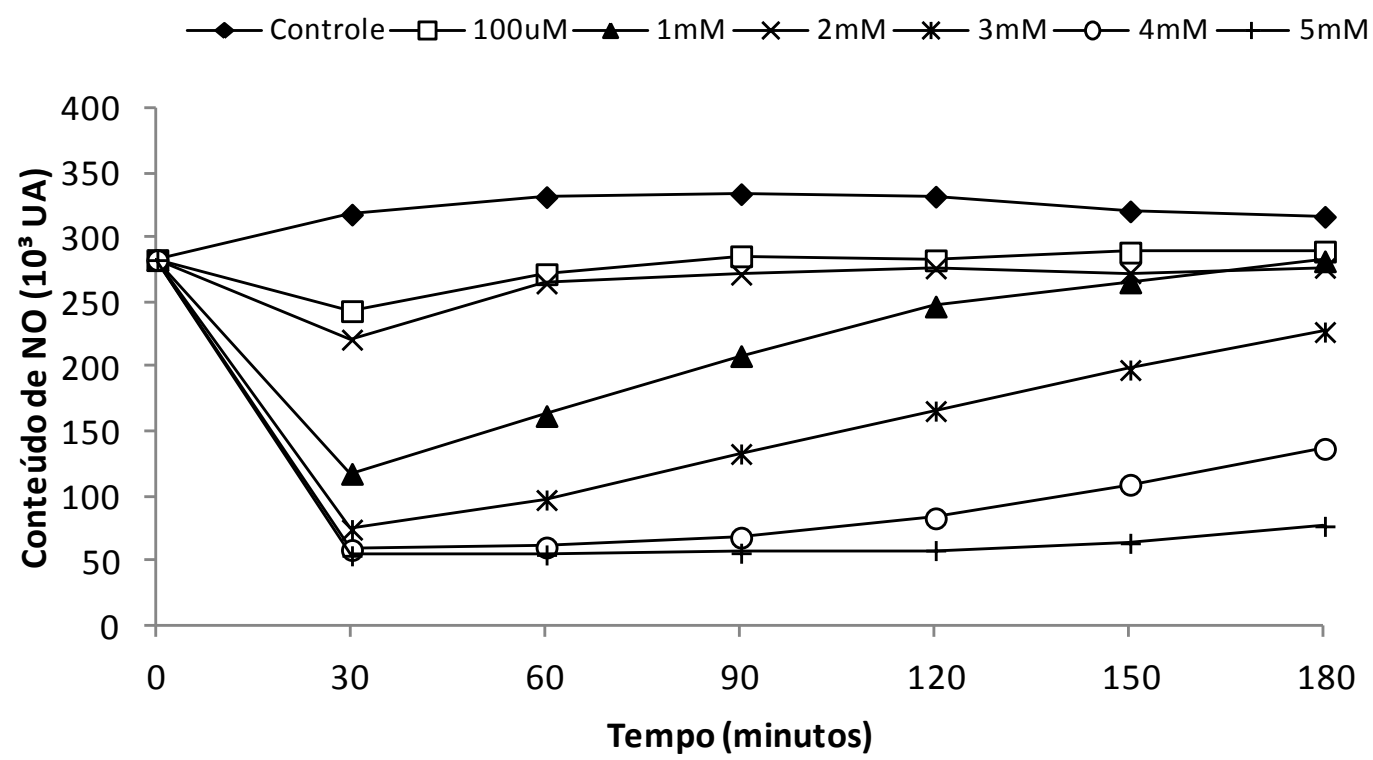

Figura suplementar 2. Conteúdo de NO intracelular em suspensões celulares de $A$. angustifolia suplementadas com diferentes concentrações de PTIO $(0 ; 0,1 ; 1 ; 2 ; 3 ; 4$ e 5 mM). Média \pm desvio padrão, $n=3$.

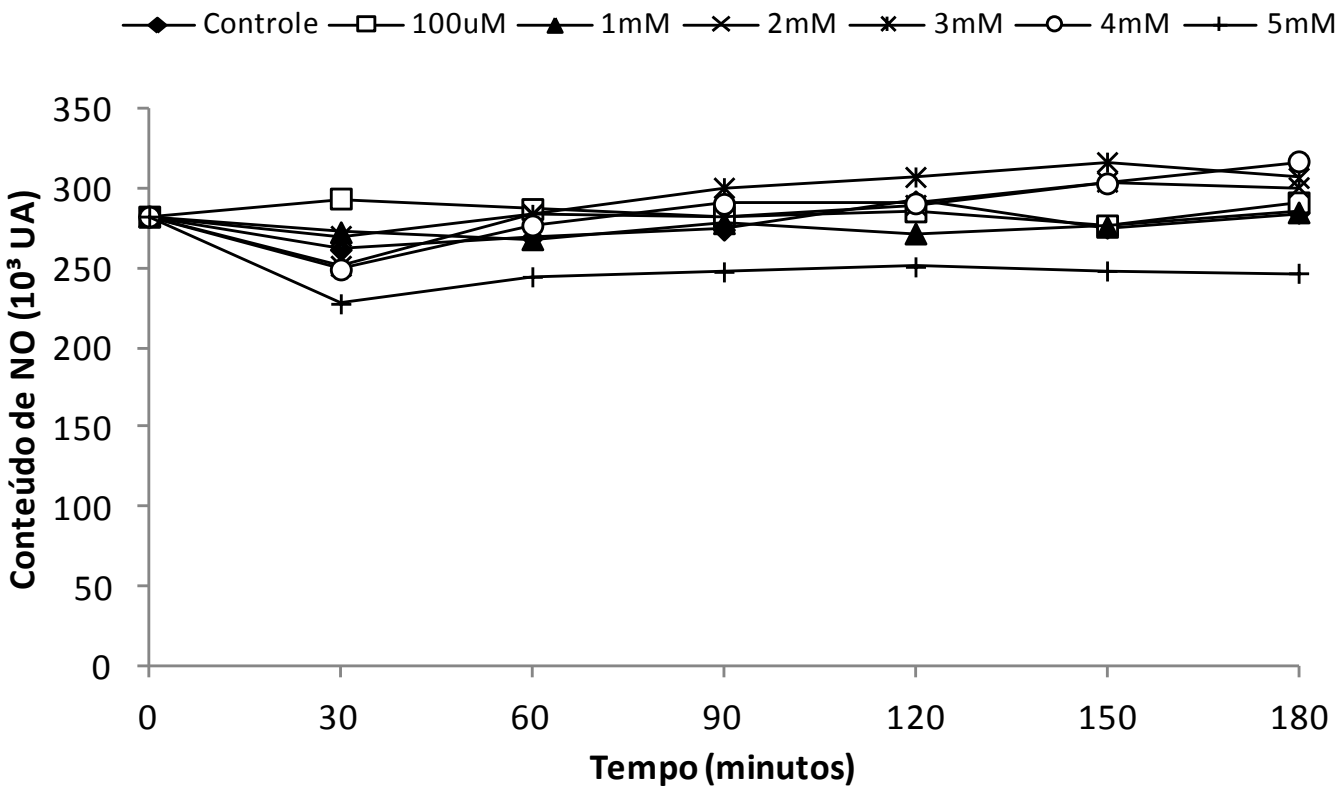

Figura suplementar 3. Conteúdo de $\mathrm{NO}$ intracelular em suspensões celulares de $A$. angustifolia suplementadas com diferentes concentrações de L-NAME $(0 ; 0,1 ; 1 ; 2 ; 3 ; 4$ e 5 $m M)$. Média \pm desvio padrão, $n=3$. 